Bericht Nr. 212

\title{
Swiss Research in Building Heating Conservation
}

\author{
S.R. Hastings/R.C. Ruggli
}




\title{
Swiss Research in Building Heating Conservation
}

\author{
S.R. Hastings / R. C. Ruggli*
}

* S. Robert Hastings, MSc Arch./Roger C. Ruggli, dipl. Arch. ETH, EMPA, Section Applied Physics in Building, Überlandstrasse 129, $\mathrm{CH}-8600$ Dübendorf

Prepared for Passive and Hybrid Solar Energy Division Office of Solar Heating Technology, US Department of Energy, Washington, D.S. 20582, and Swiss National Energy Research Fund, NEFF, $\mathrm{CH}-4000$ Basel, Switzerland

This report is also available as NBSIR 83-2724 at National Technical Information Service (NTIS), Springfield, VA. 22161, USA 


\section{ABSTRACT}

Swiss research on heating energy conservation in buildings is presented to encourage communication among researchers. A background on Switzerland's climate, geography, construction industry, and energy situation is included to provide a context for the subsequent review of a sample of research projects. Each project is described with a statement of research obejctives, technical approach taken, projects status, sample findings, future work planned or recommended, and resulting publications. The sample of projects is taken from the subjects of community scale solar concepts, mathematical simulation, instrumented test cabins, instrumented buildings, and design tools and data bases. The final section discusses a structure for surveying research projects in a country in order to examine where efforts are now concentrated and what subjects are not adressed. Swiss research is examined using this structure. 
It may be considered as a particularly lucky event that in 1980 a co-operation between members of the National Bureau of Standards (NBS) and the Swiss Federal Laboratories for Materials Testing (EMPA) was started to investigate on a broad basis the problems of heating energy conservation. This work, effectively sponsored by the U.S. Department of Energy (DOE) and the Swiss National Energy Research Fund (NEFF), can now be presented in adequate form.

By no means can sponsorship be confined to the institutions mentioned. In fact many local authorities, many firms and private persons made significant contributions in enabling the scientists to work in a great number of different buildings under a great variety of conditions ranging from those of a built-in laboratory to those of practical use. And in certain cases (for instance that of several buildings owned by the City of Zurich) it was possible to draw long-term service comparisons between identical buildings with different energy conservation techniques.

So the results of the present study have obtained a general importance going beyond the small country where the investigation was carried out. It is for this reason that the work is now made available to a broad public.

T.H. Erismann

President of EMPA 


\section{ACKNOWLEDGEMENTS}

The preparation of this report has been co-sponsored by the U.S. National Bureau of Standards (NBS), Center for Building Technology with funding from the U.S. Department of Energy (DOE), Solar Cities and Towns Program; and the Swiss Federal Laboratories for Materials Testing (EMPA) with funding from the National Energy Research Fund (NEFF).

The authors wish to thank the following individuals:

- Frank Deserio, DOE Solar Cities and Towns Program leader.

- Francis T. Ventre and Robert D. Dikkers of the Center for Building Technology and the members of the NBS staff who served as technical reviewers.

- R. Sagelsdorff, EMPA, Building Physics Group Leader and technical reviewers

- W. Thut and M. Epprecht, Vice Presidents of NEFF

- Each of the reported project researchers

\section{Notice of Disclaimer}

Commercial products are identified only for the sake of completeness. Such identification does not constitute endorsement by NBS or imply that they are necessarily the most suited. 


\section{Conversion Factors}

\section{$\underline{\text { Length }}$}

1 centimeter $(\mathrm{cm})=$

$=0.3937$ inches (in)

1 meter $(\mathrm{m})$

$=$

3.281 feet $(\mathrm{ft})$

1 kilometer (km)

$=0.62 \mathrm{miles}$

Area

1 square meter $\left(\mathrm{m}^{3}\right)=$

1 square kilometer $\left(\mathrm{km}^{2}\right)=$

Volume

1 cubic meter $\left(\mathrm{m}^{3}\right)$

1 liter (l)

Mass

1 kilogram (kg)

$=$

\section{Temperature}

1 degree Celsius $\left({ }^{\circ} \mathrm{C}, \mathrm{K}\right)=$

$=$

35.33 cubic feet $\left(\mathrm{ft}^{3}\right)$

0.264 gallons

10.76 square feet $\left(\mathrm{ft}^{2}\right)$

0.386 square miles

2.2 pounds ( $1 \mathrm{~b}$ )
1 kilojoule (kJ)
$=$
0.948 Btu

\section{Power}

1 watt (W)

$1 \mathrm{~W} / \mathrm{m}^{2}$

$1 \mathrm{~W} / \mathrm{m}^{2} \mathrm{~K}$
$=$

$=$

$=$

$5 / 9\left({ }^{\circ} \mathrm{F}-32\right)$

\section{Monetary}

$1 \mathrm{SFr}$ 
CONTENTS

INTRODUCTION

1. BACKGROUND 3

2. PROJECTS 15

Concept Development

2.1 A Community Wood/Solar District Heating System 17

2.2 Settlement pattern and heating optimization 23 Mathematical Simulation.

2.3 DOE 2. Implementation and Validation 31

2.4 DEROB Implementation and Validation 37

Test Cabin Measurement.

2.5 STESO Test Cabins 43

$\begin{array}{lll}2.6 & \text { Solar Trap } & 47\end{array}$

2.7 Maugwil Test Cabins $\quad 55$

Instrumented Building Measurement

2.8 Three passive solar houses $\quad 65$

2.9 An attached greenhouse near Zug 75

2.10 Limmatstrasse Apartment Building Retrofit 81

2.11 Chaumiere Apartment Building 93

2.12 Zug Apartment Building 97

$\begin{array}{ll}2.13 & 101\end{array}$

Design Tool and Data Development

2.14 Automated Climate Data Collection Net 105

2.15 Occupant Factor/Air Change Rate Data Base 109

2.16 Impulse Program: Component Testing Data Base 123

2.17 A Simplified Method for Calculating Heating Demand 127

$\begin{array}{ll}\text { 3. OBSERVATIONS } & 135\end{array}$ 


\section{INTRODUCTION}

Switzerland and the United States share many common problems in reducing energy consumption. To a certain extent, the problems in Switzerland are magnified relative to the U.S. All oil consumed in Switzerland must be imported and a higher than average price per barrel must be paid.

This report focuses on Swiss research to reduce energy consumption of buildings through conservation and passive solar energy use. Emphasis is given to research on the building envelope and how it responds to the ambient climate relative to the desired controlled interior environment. Figure 1 illustrates this relationship.

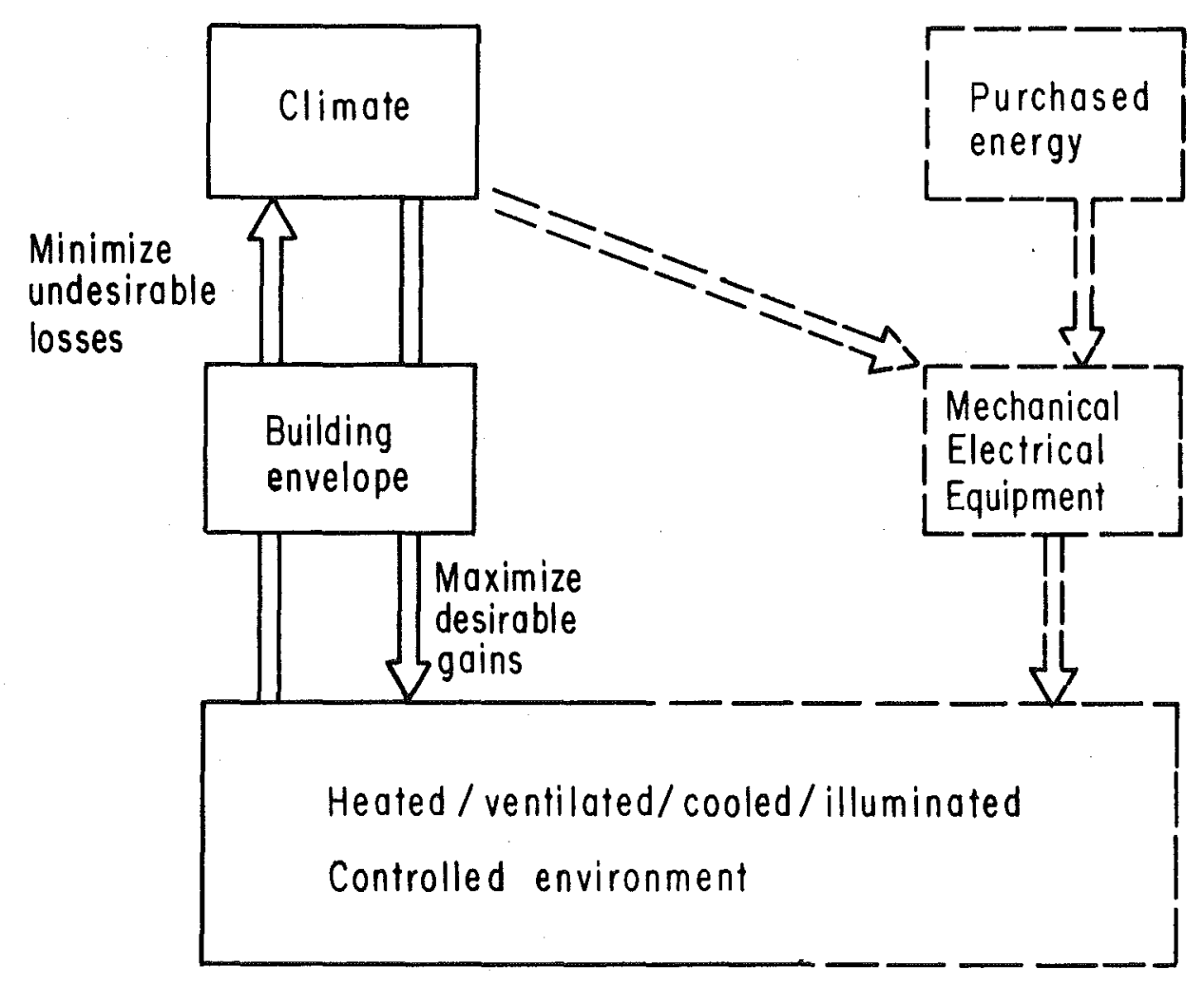

Fig. 1 Climate, Building Envelope, Interior Environment Interaction 
This report draws upon two research status seminars:

An energy conservation research seminar (1) convened by EMPA provided a broad cross section of the majority of he projects dealing with conservation, and a similar seminar (2) convened by the Swiss Federal Institute of Technology in Lausanne (EPFL) provided a cross section of solar research projects. For selected projects additional documentation was then collected, and as time permitted, the individual researchers were contacted.

This report begins with a background to provide a context for building conservation research. Briefly discussed are the Swiss climate, terrain, regulations, financing, and construction philosophy. Also covered are gross statistics on national energy uses and sources, Swiss building research funds and institutions, and research coordination.

The body of the report presents a sample of projects involving building components, systems, and supporting research. The projects have been grouped by research approach as follows: concept generation, mathematical simulations, test cells, instrumented buildings, and design tools and data. Each project review consists of a statement of background, objectives, approach, status, example results, comments by the authors, and publications.

In the final section of the report the authors identify in what research areas Switzerland has concentrated and what future directions Switzerland may take in the field of building heating conservation research.

(1) EMPA, Schweizerisches Status Seminar: Wärmeschutz-Forschung im Hochbau, Abteilung Bauphysik, CH 8600 Dübendorf, October 1980

(2) Symposium: sur la recherche et le developpement en energie solaire en Suisse, Dept. of Physique, Groupe de Recherche en Energie Solaire, Swiss Federal Institute of Technology, CH 1001 Lausanne, Oct. 1980 
$-3-$

To better consider Swiss building heating conservation research it is important to understand the constraints and opportunities in Switzerland. This section provides a brief background on Swiss climate, terrain, population densities and distribution, regulations, financing, construction philosophy, and energy sources and uses. Also included are a background of major research sponsors and institutions.
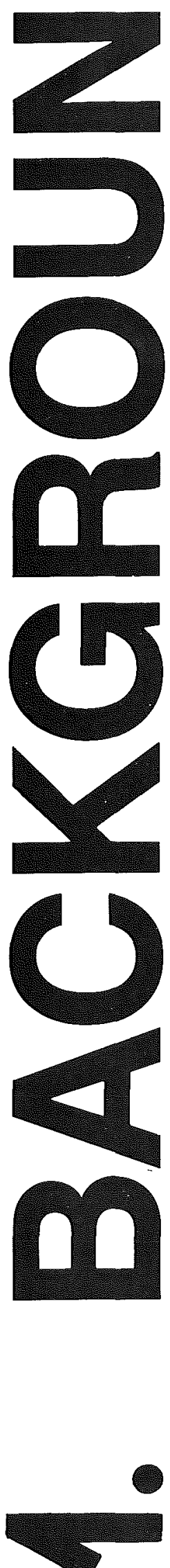


\section{$\underline{\text { Climate }}$}

Switzerland can be divided into three main climatic zones. Zone 1 has a middle-European climate, Zone 2 has a Mediterranean climate, and Zone 3 has an alpine climate. Heating degree days (US ASHRAE ${ }^{\circ} \mathrm{F}$ method) for a city in each of the three zones are shown on the map in Figure 2.

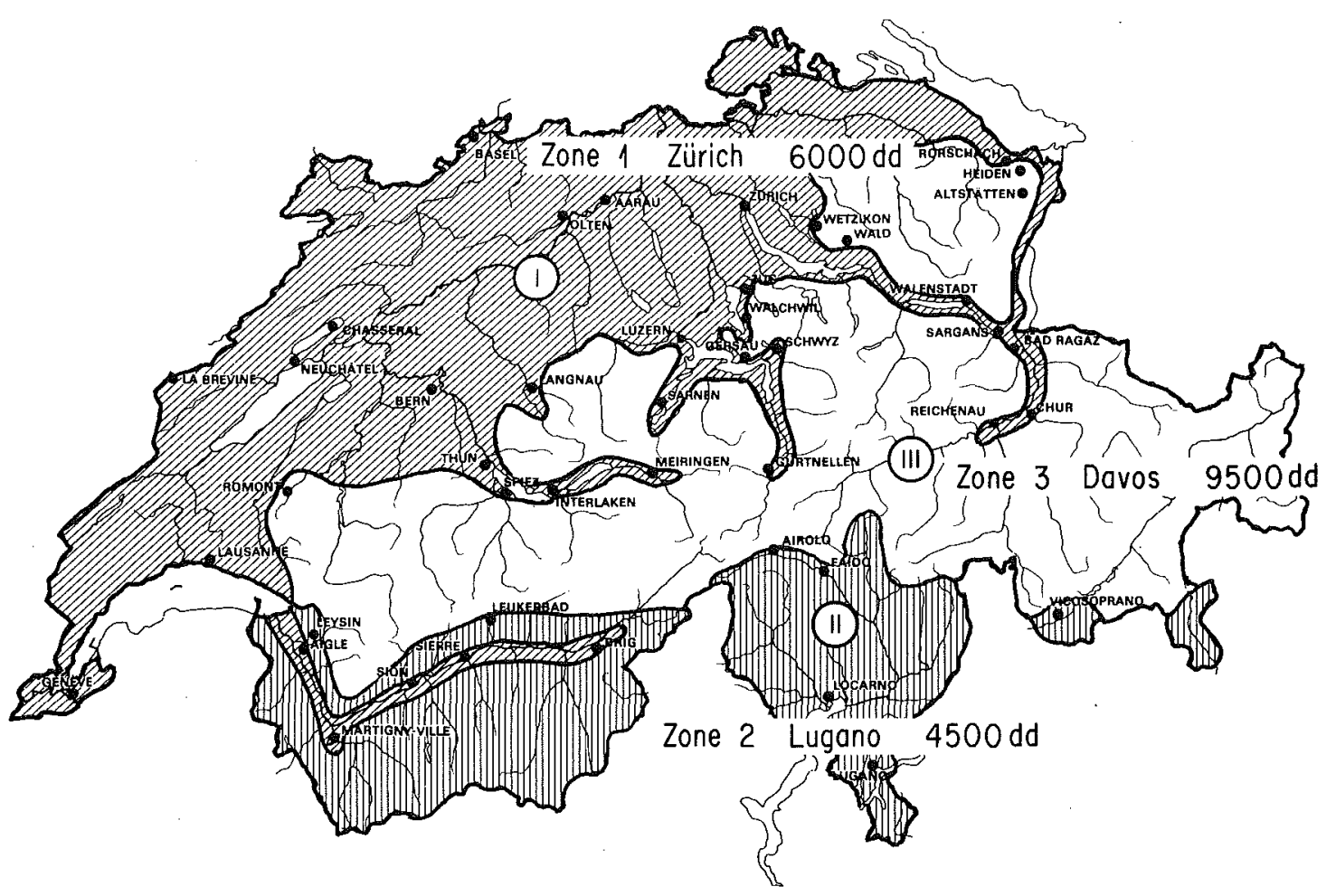

Fig. 2 Climate Zones of Switzerland

There are pronounced local climate differences within each climate zone. Differences in solar radiation result from regional patterns of cloud cover and also from regional shadowing by mountains. Figure 3a illustrates the actual number of hours of sunlight (the white length of the bars) relative to the total possible at that latitude (the total length of the bars). The width of the bars indicates the curtailment of sunlight due to shadowing by the mountains, a narrow bar indicating extensive shadowing. Figure $3 \mathrm{~b}$ graphs the global and diffuse solar radiation for Zürich (Kloten), Davos and Locarno in comparison to Boston and Albuquerque. 

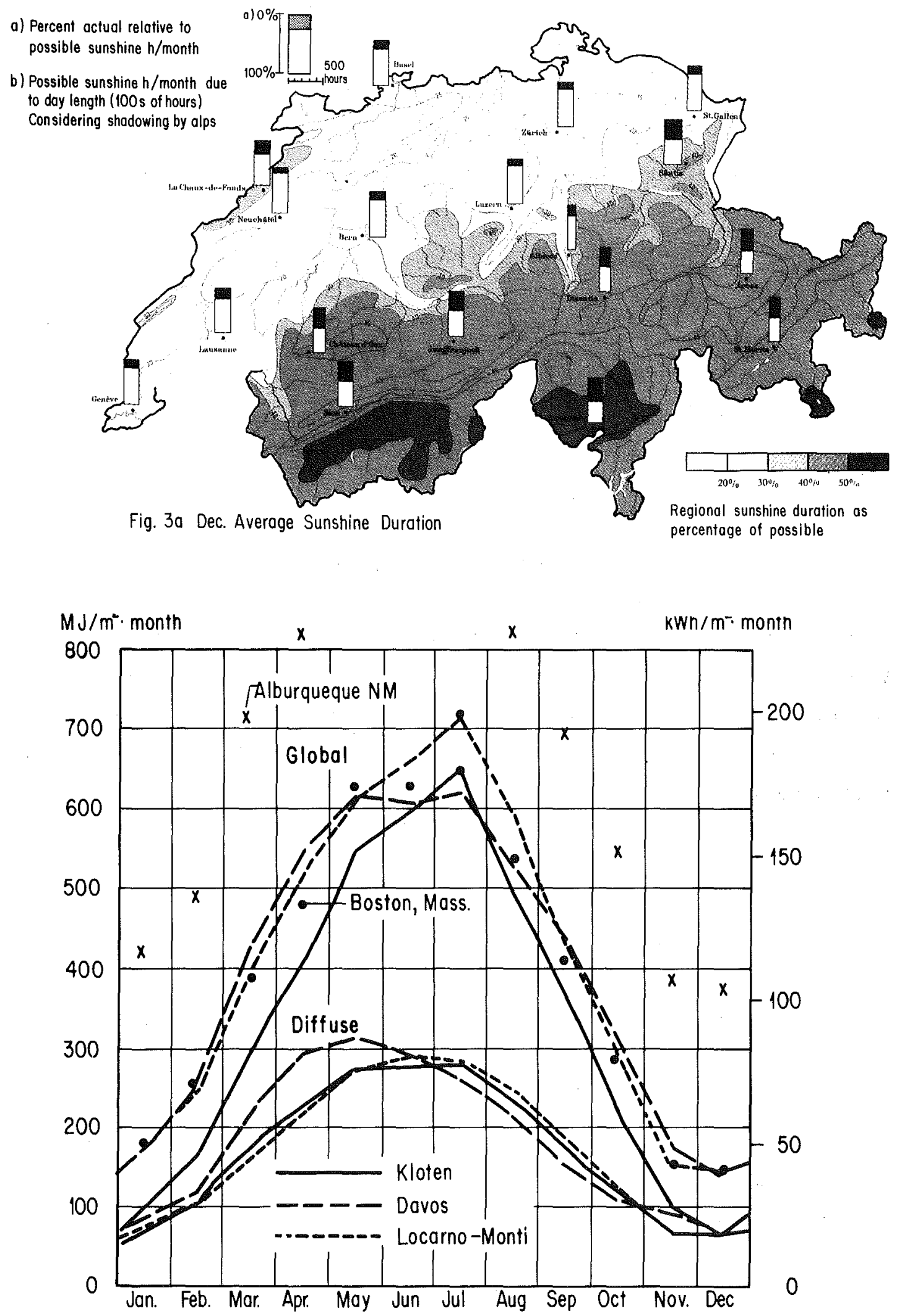

Fig. 3b Horizontal Global and Diffuse Solar Radiation 


\section{Terrain-Population}

Switzerland has a total land area of $41,293 \mathrm{~km}^{2}$ which is about twice the size of New Jersey or a tenth the size of California. The population density is three times greater than in California and 40 percent that of New Jersey.

Land uses can be divided as follows:

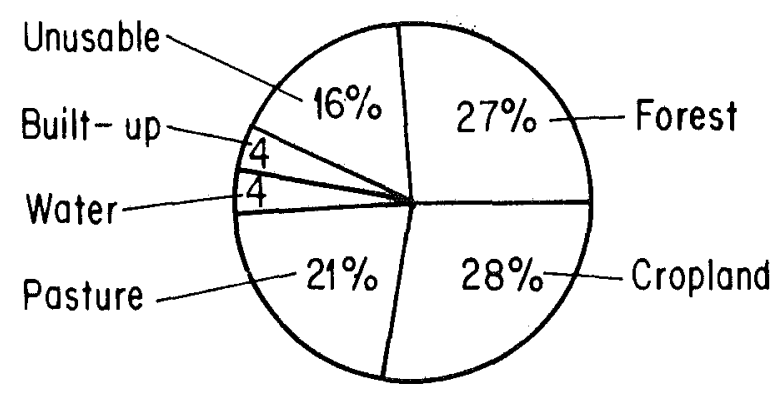

Fig. 4 Land Use in Switzerland

Most of the population live in the midlands between the Jura and the Alps (climate zone 1 ) at an elevation between 400 and $600 \mathrm{~m}$. This is the main useable land zone and of course the main building zone as well. Concentrations of population are indicated by dark areas on the following map.

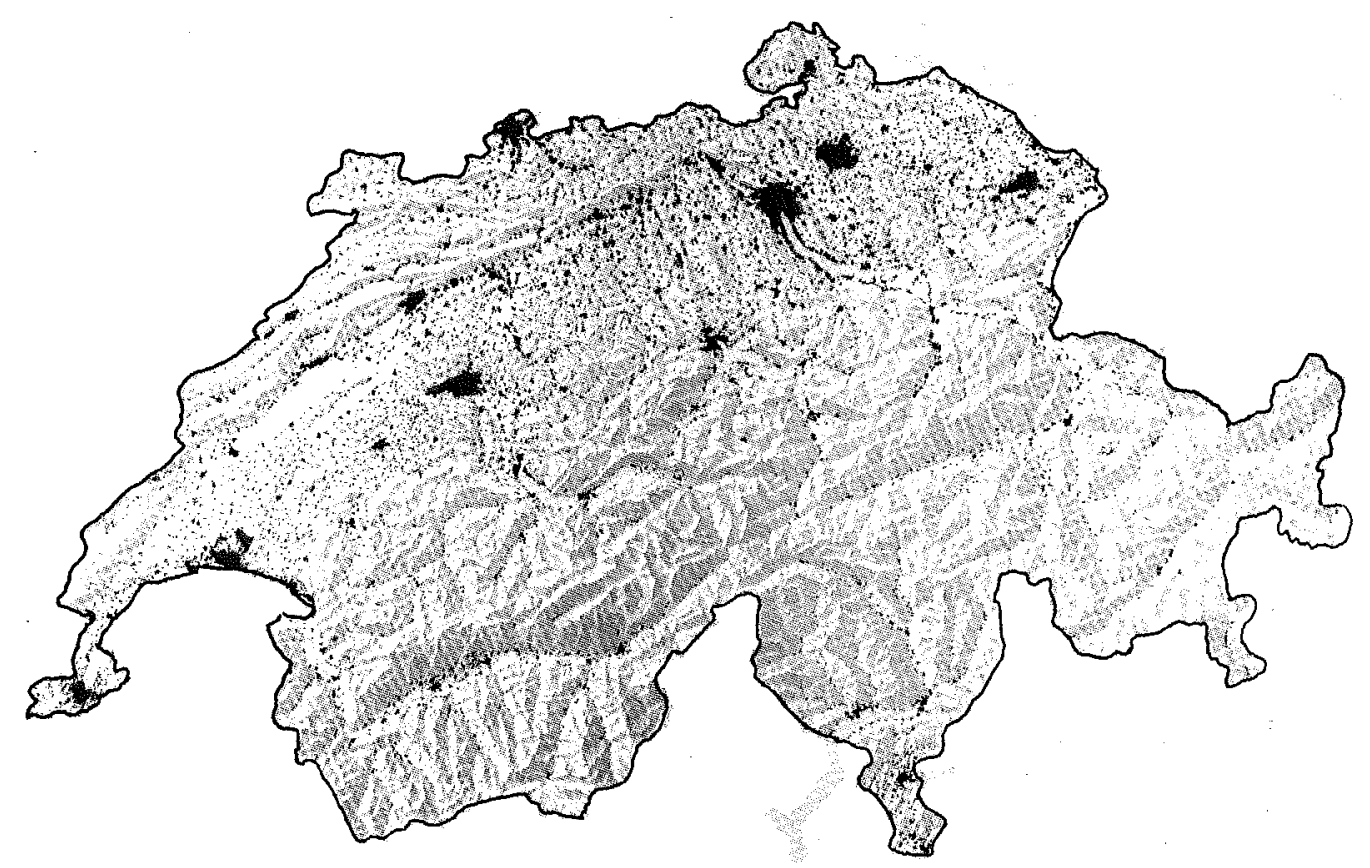

Fig.5 Population Distribution in Switzerland 


\section{$\underline{\text { Regulation }}$}

Contemporary Swiss building patterns are strongly influenced by local regulations and can be quite different in each municipality (the lowest governing body). Regulations are quite detailed and determine parameters such as building height and size, roof form, colors, U-values, number of parking spaces, setback distances, amount and size of windows per $\mathrm{m}^{2}$ of floor area, ceiling height etc. Safety regulations are similar in all of Switzerland. Example parameters include: fire regulations, heights of balustrades, width of staircases etc.

Other important factors influencing building come from the federal planing law, which is applied by each Canton (State). Those laws are mainly zoning regulations specifying allowable land uses for designated areas. (e.g. single family, multifamily, commercial, industrial).

The major difference between land use regulation in Switzerland and in the U.S. is that in Switzerland regulation has largely confined building to within built areas with a defined boundary. By contrast, in the U.S. building tends not to be confined but to scatter beyond the boundaries of a built-up area.

Effective land use regulation is possible in Switzerland because there is no inherent right to develop land. Therefore, open space can be preserved without the inordinate expense of compensating land owners. The result of this policy is extensive tracts of forest and farmland immediately adjacent to tightly defined dense urban areas.

\section{Financing}

The price of land in Switzerland is extremely high. At the moment land prices in U.S. dollars vary from $\$ 75$ to $\$ 250 / \mathrm{m} 2$ for residential lots in outlying towns. (City residential lots are of course much higher). 
Construction costs for a small house begin at $\$ 175,000$. Including the cost of a minimal lot in an outlying town the total cost for a modest house is therefor seldom less than $\$ 250,000$. Accordingly, the great majority of the population live in apartments.

Such prices are only conceivable for the few people who do buy houses because of the financing mechanisms available in Switzerland. A 20 percent downpayment is usually required by a bank. 60 percent is then paid by the bank in a first loan, typically at an interest rate between six and eight percent.The bank provides the remaining 20 percent as a second loan at a rate $1 / 2$ percent above the first loan. Both interest rates are variable. The second loan is amortized over 15 years, the first loan is never paid back and the monthly payments accordingly include no repayment of the principal, only interest payments. This testifies to the fact that houses in Switzerland are built for long term service.

\section{Construction Philosophy}

Longevity is a dominant characteristic of Swiss construction philosophy. This manifests itself in the materials used: concrete, brick, roofing tiles, copper flashing and rainwater conductors, etc.

The residence is considered a place of security. An underground bombshelter must be provided for each new dwelling. The shelter is a $40 \mathrm{~cm}$ thick, heavily reinforced concrete, enclosure with a concrete vault door, and an air filtration system. Another residential design feature is the attention given to preventing forced entry. Locks are built to be "impenetrable". This can be a disadvantage, however, in case of fire since locked doors are commonly impenetrable in either direction without a key. 


\section{Background on Energy Use Patterns}

Figures $6 \mathrm{a}, \mathrm{b}$, and $\mathrm{c}$ illustrate sources, end uses, and end use forms of energy. Noteworthy is the high percentage of total energy use which comes from electricity, and the large percentage which nuclear energy represents. Significant for solar energy use consideration is the fact that 45 percent of Swiss end-use energy is used for heating at temperatures not exceeding $80^{\circ} \mathrm{C}$. This $10 \mathrm{w}$ temperature heat demand is presently being met by high temperature (e.g. $1000^{\circ} \mathrm{C}$ ) sources (1). Conservation and solar energy use can help reduce the excessive reliance on high quality energy sources for low temperature end uses.

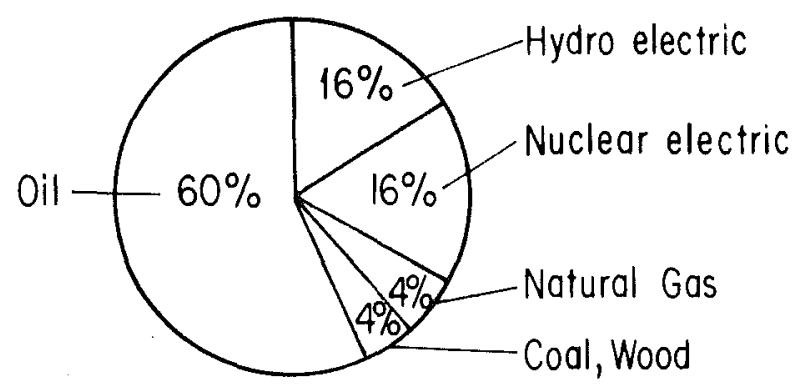

Fig.6a Swiss Energy Sources
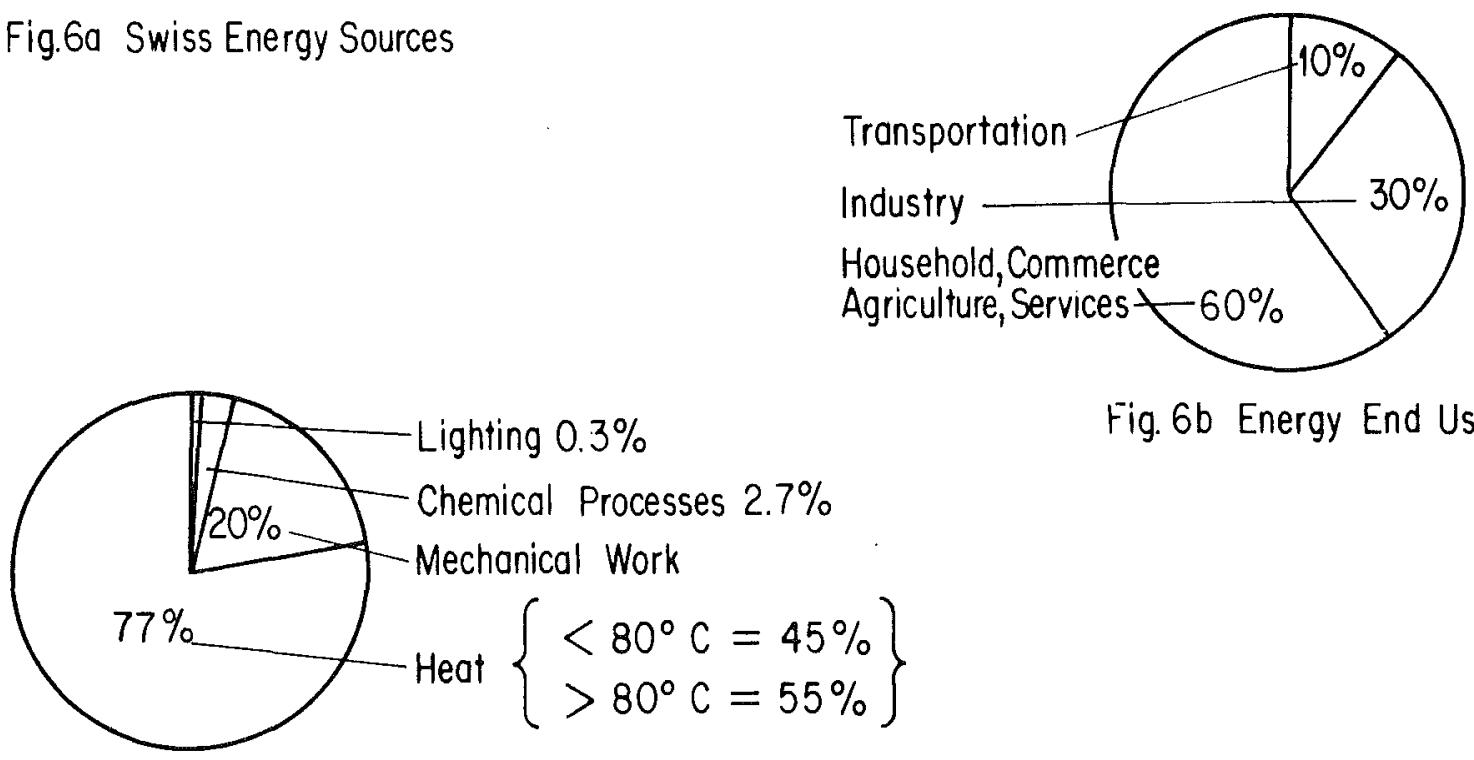

Fig. 6c Energy End Use Forms

(1) Source: Bundesamt für Energiewirtschaft, "Schweizerische Gesamtenergiestatistik", Bern, June 1981. 
The primary Swiss building energy research sponsor is the National Energy Research Fund, NEFF. It was created in 1978 by a consortion of Swiss Industries to support energy research in collaboration with the federal government. In $1980 \mathrm{NEFF}$ spent $\$ 5.5$ million on research projects of which half was spent on research in building energy conservation and alternative energy sources. (1)

Another major research fund is the National Fund (NF), a government institution which spent $\$ 4.5$ million on energy research over the last five years. The NF tends to finance socio-economic research in contrast to the NEFF which tends to finance technical research.

A third research sponsor is the Commission for the Advancement of Scientific Research (Bundesamt für Konjunkturfragen), another government office which acts mainly as an intermediary between researchers and interested industries. It co-finances only projects that are of immediate interest to industry. Industry must co-finance at least 50 percent of a project's costs.

Figure 7 presents total energy research expenditures from all sources (2).

(1) NEFF, "Jahresbericht 1980", Nationaler Energie-Forschungs-Fond, Basel.

(2) Bundesamt für Energiewirtschaft, Bern, June 1981. 


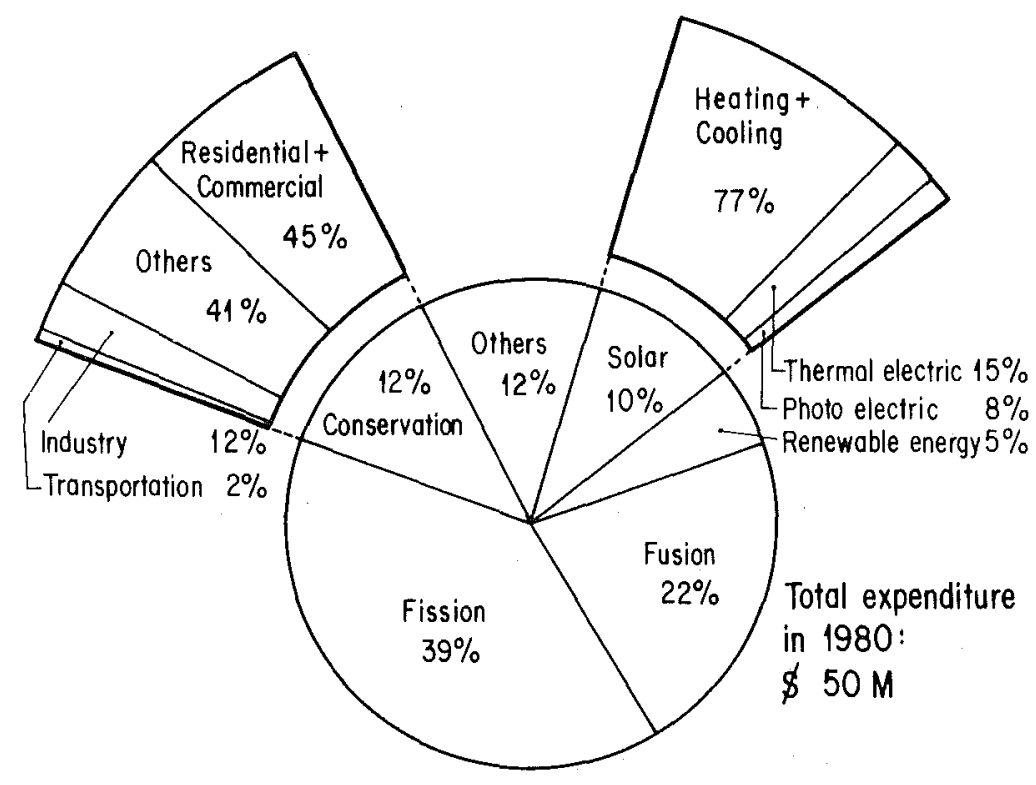

Fig. 7 Energy Research Expenditures by Percentages

\section{Primary Building Research Institutions}

EMPA Swiss Federal Laboratories for Materials Testing

Ueberlandstrasse 129

CH 8600 Dübendorf

At the EMPA the Applied Physics in Building section, under the leadership of $\mathrm{Mr}$. R. Sagelsdorff is mainly involved in research in energy conservation, active and passive solar energy use and basic building physics. The EMPA is an Annexe to the Swiss Federal Institute of Technology.

EIR Swiss Federal Institute for Reactor Research, CH 5303 Wuerenlingen

The EIR is involved in testing heat pumps, solar collectors, and photovoltaics.

Contact: Dr. Kesselring 
EPFL Swiss Federal Institute of Technology Lausanne

14, Av. de l'église anglaise

$\mathrm{CH} 1006$ Lausanne

At the EPFL the Solar Energy Research Group, Theoretical

Physics Laboratories, under the leadership of Prof. A. Faist is involved in test cell measurement, instrumented building monitoring and computer simulation.

University of Geneva 32 Boulevard d'Ivoy

CH 1211 Geneva

At the University of Geneva the Solar Energy Group under the leadership of Prof. A. Giovannini is involved in assembling a literature data base on technical developments and applications in the fields of energy conservation in buildings and household appliances.

ETHZ Swiss Federal Institute of Technology, Zürich Einsteinstrasse

CH 8049 Zürich

The ETHZ researches energy conservation and solar energy through it's institutes:

$\mathrm{HBF}$ (Building research institute)

The HBF is involved in research application for

university teaching.

Contact : Prof H. Kunz

HBT (Institute for Building Techniques)

The HBT is involved in building related energy

conservation techniques.

Contact : Prof. H. Hauri 
HTL Brugg-Windisch

$$
\begin{aligned}
& \text { Klosterzelgstrasse } \\
& \text { CH } 5200 \text { Brugg-Windisch }
\end{aligned}
$$

The HTL (Technical High-School) Brugg-Windisch is host to INFOSOLAR, a solar literature reference center. Contact : Mr. Thomas Fisch

ZTL (Technica1 Highschool of Central Switzerland) 6048 Horw

Contact : Mr. Hüsler 


\section{Energy Research Coordination}

International building energy research coordination in Switzerland is principaly accomplished through the International Energy Agency (IEA). Swiss contacts are: Dr. L. Dubal and Dr. G.Schriber, Federal Energy Office in Bern (BEW); Dr. P.Hartmann, (EMPA); and Prof. A.Faist, (EPFL).

NEFF funded building energy conservation research is coordinated by a specially created coordination project, KWH, resident at EMPA. The project's function is to ensure information exchange among the numerous NEFF funded projects at various institutions and private firms, and to provide NEFF with recommendations for future research directions.

INFOSOLAR, another NEFF funded project, is a documentation/information resource center for commercial product literature in the subject area of solar energy and energy conservation.

SIA, the Swiss Engineers and Architects Association, publishes standards and documentation on all aspects of building construction. Several reports on energy conservation have been published. A background publication on solar energy use in buildings was published in 1982 (SIA 380.5).

SITI, the Swiss Institute for Technical Information provides literature research for any institution or individual on any technical subject. Searches are done using a computer system, and through telephone connection to more than 100 international data-banks.

Research coordination is also done by the "Schulrat", the highest administrative organ of the Federal Institutes of Technology. This organ coordinates research at the ETHZ, EPFL, EMPA, and EIR. 
The following research projects provide a sample of work ongoing or recently completed in Switzerland. For each project a brief background summary is provided followed by a statement of objectives, approach, status, example results, and publications. The number of projects selected in each general area reflects the authors' perception of the extent of activity in that general area. The reported status reflects the status as of August 1981. The publications listed are those available from the given project up to that date.
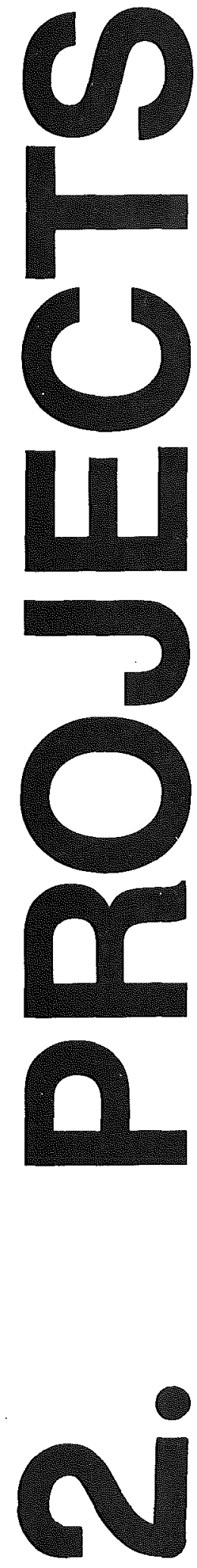


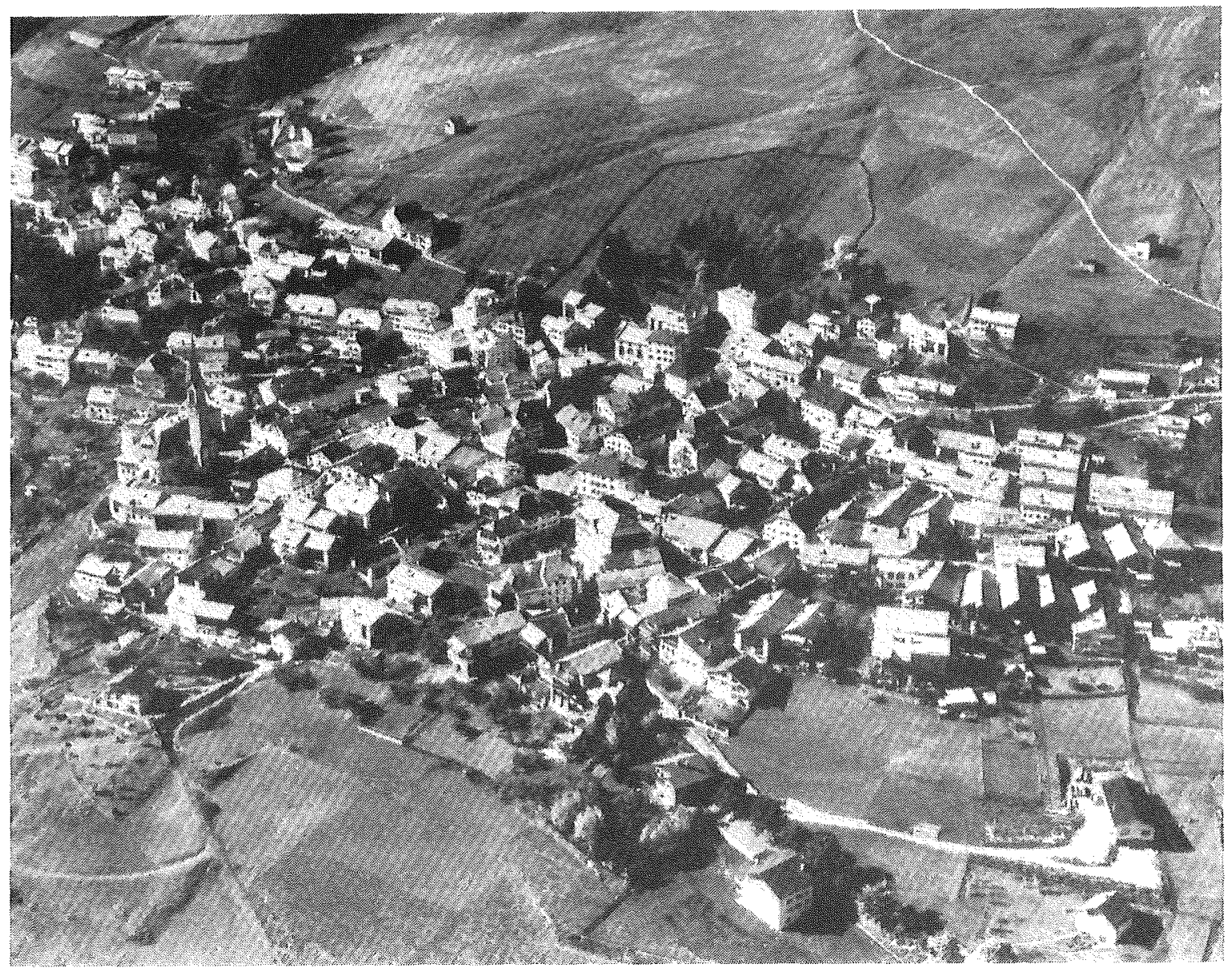

\subsection{A COMMUNITY WOOD/SOLAR DISTRICT HEATING SYSTEM}

\section{BACKGROUND}

A complex wood/solar district heating system has been designed for Sent, a small mountain community of approximately 400 dwelling units. The system design is as follows: The heat from solar collectors is extracted by heat pump evaporator elements configured as the solar absorbing surface. The heat pumps are powered by internal combustion engines. These engines are fueled by gas from wood gasification units. The heat from the heat pumps is distributed in a pipe network to the individual residences. The design is now in the pre-bid stage. J. Buchli and J. Studach of the engineering firm of IGEK are the project leaders. 


\section{Objectives}

- Efficient use of solar and wood energy as heat sources for space and domestic water heating at a community scale.

- Efficient distribution of heat at low temperatures with minimal transmission losses and direct use of the delivered heat at the individual terminals.

- Achieve economic efficiency considering both capital and operating costs.

\section{Approach}

A wood gasification system was determined to be a valuable approach to supplying heat to a central system because it permits the more efficient combustion of waste wood, e.g. branches, bark, chips. The wood gas is used to fuel internal combustion engines which drive solar assisted heat pumps. The solar assistance is accomplished by the heat pump evaporator elements which are treated with a black varnish and comprise the absorber surface of solar collectors. Distribution of heat from the heat pumps is accomplished with a bundled four pipe system consisting of supply and return water pipes for space heating and for domestic water. The domestic hot water is used directly from the copper piping without a heat exchanger at the terminals. A single mantel of insulation encases the four pipes. Each terminal has a flow meter but no calorimeter for measuring heat extraction. This favors users with a total or partial low temperature heating system (e.g. radiant floors) which extracts the maximum heat from the water. The result is increased capacity of the distribution system and more efficient use of the heat pumps. The following plan illustrates the layout of the central heating plant and the distribution system with the location of the central plant in the community. 


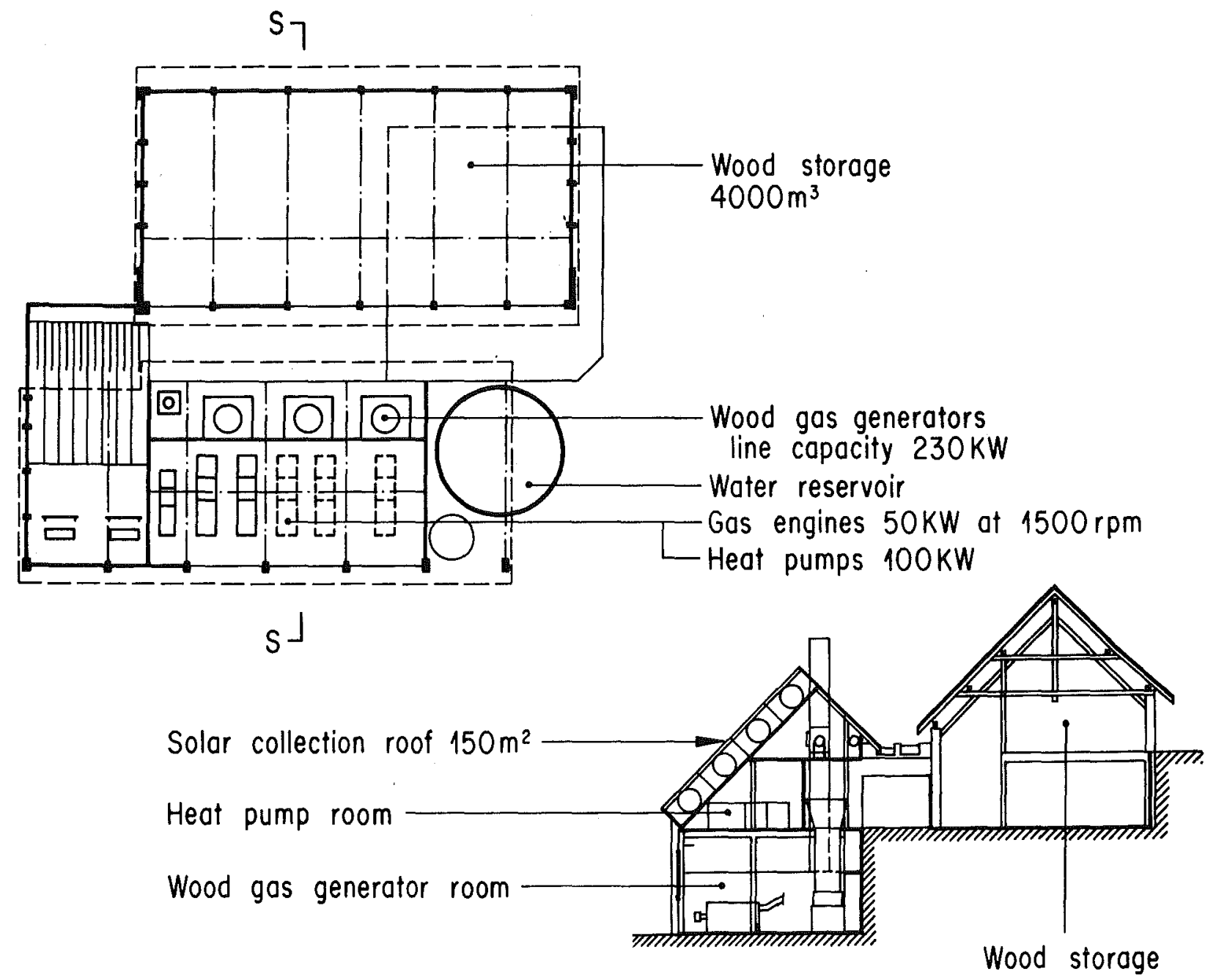

Fig. 80 Plan and Cross Section of the Central Heating Plan

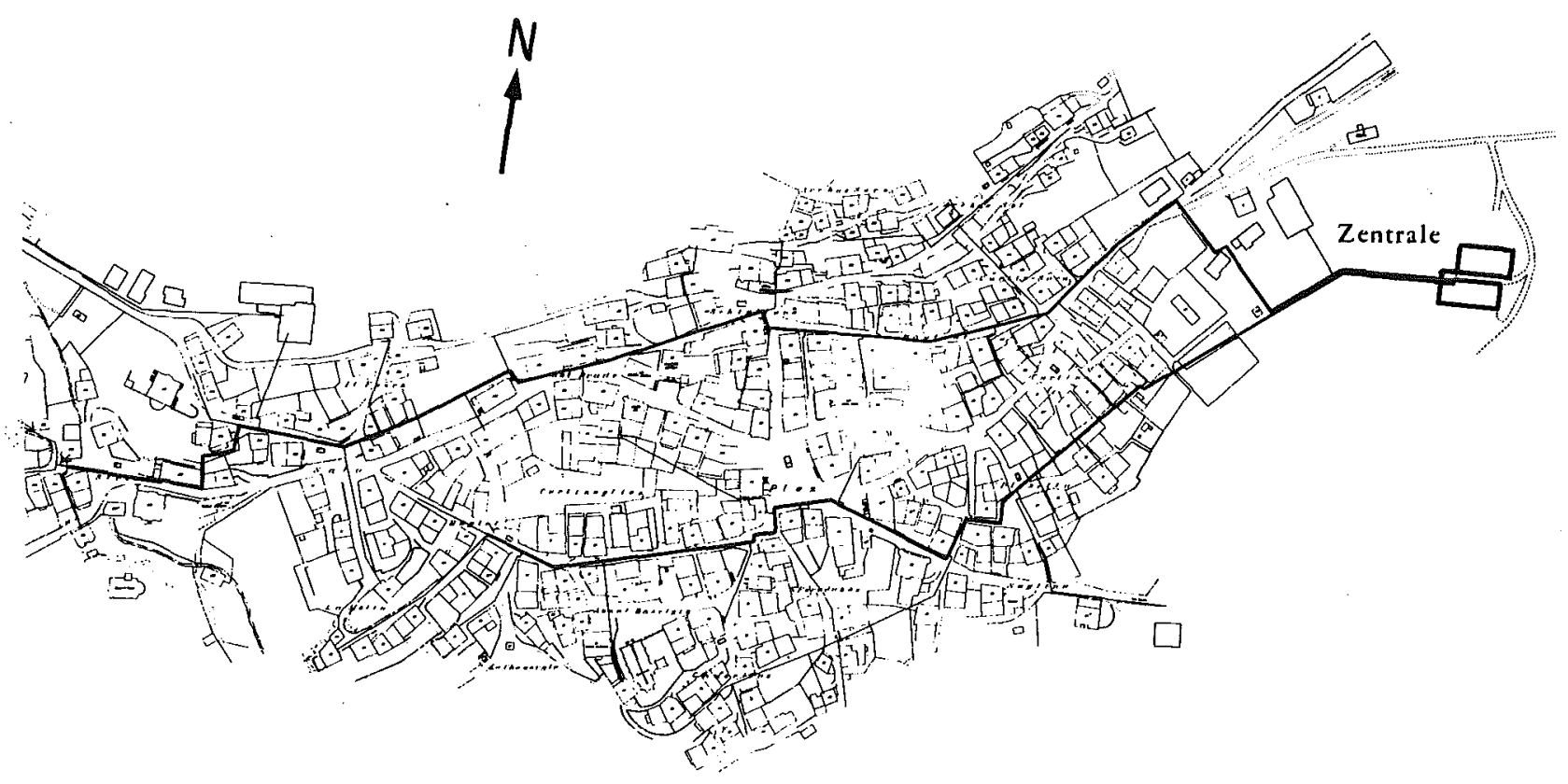

Fig. 8b Map of Sent Distribution Lines 


\section{Status}

The design of the system has been completed and approved in principle by the town and the sponsors (the National Energy Research Fund, the Bank of the Canton of Graubünden and the Community of Sent). The engineers are now in a pre-bid discussion phase with selected contractors.

\section{Example Results}

The calculated benefit of the system is based on several assumptions:

The existing energy sources and their proportion of useage are:

$$
\begin{array}{lrrr}
\text { - wood, } & 21 \% & (5,280 \mathrm{GJ} / \mathrm{yr}) \\
\text { - fuel oil, } & 75 \%(522,700 \ell= & 18,440 \mathrm{GJ} / \mathrm{yr}) \\
\text { - electricity, } & 4 \% & & (1,040 \mathrm{GJ} / \mathrm{yr}) \\
& & \text { total } & 24,760 \mathrm{GJ} / \mathrm{yr})
\end{array}
$$

The number of occupied buildings varies substantially by season with occupancy peaks of 100 percent occurring in July and August and of 90 percent in February and March. Minimum occupancies of 60 percent occur in November and May.

The energy consumption of the community is expected to increase between now and the year 2000 as a result of the addition of residences to the present inventory, and as a result of an expected increase in the percentage of dwellings occupied the entire year.

Using these assumptions, a computer model was run to project heating energy use if no steps were taken, if conservation measures were applied, and if conservation along with the proposed heating system were implemented. Figure 9 graphs these three options. 


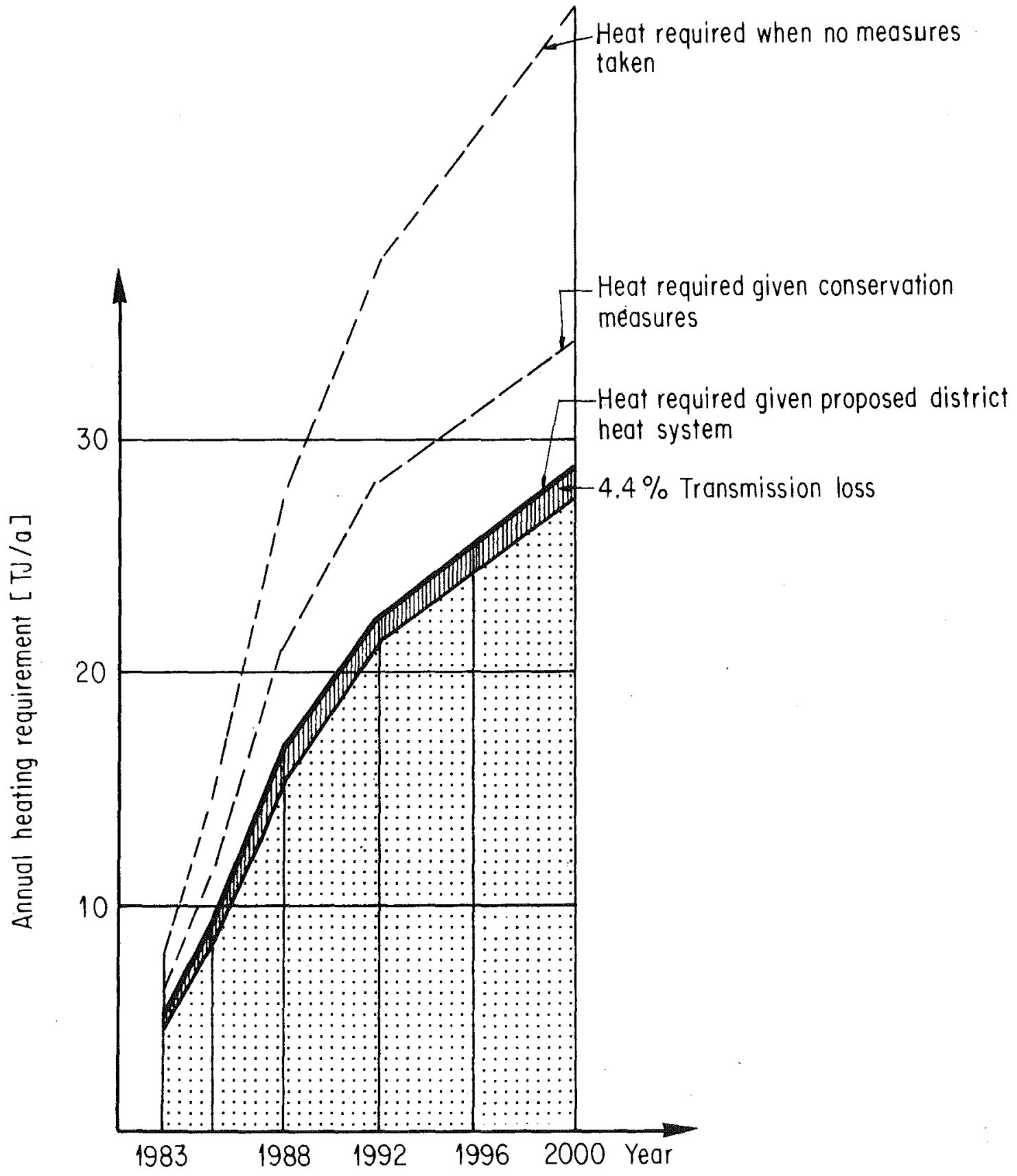

Fig. 9 Annual Heating Requirements for Three Options 
By the year 2000 it is estimated that 80 percent of the dwellings would be connected to the district heating system. Investment costs for the system are estimated at $\$ 3,850,000$ to serve the resulting demand. While such costs are relatively high, the designers expected that a community also would place a value on local energy self-sufficiency and that distributed hot water for space heating or domestic hot water will be deemed as much a required part of a town infrastructure as the water supply and sewer network.

\section{$\underline{5 . \text { Comments }}$}

A heating system as complex as this may be more efficient than one might at first expect. First, one might ask, "why not burn the wood in each individual home, eliminating the distribution losses?" The proposed system may be more desirable because it can burn waste wood products efficiently and with air pollution control. One might then ask, "given the benefit of wood gasification, wouldn't it be logical to merely distribute the gas to each dwelling for combustion on site?" This alternative precludes the gains from the solar assisted heat pumps. One might finally ask, "why not collect the solar energy at each house since the sun is already a distributed resource?" This alternative is not desired because of the adverse impact on the overall aesthetics of this old mountain village, were 80 percent of the houses to be retrofitted with solar collectors. A central system with a buried distribution net minimizes the visual change imposed on the community.

\section{Publications}

Buchli, J. and Studach, J., Wärmeversorgung Sent, IGEK Engineers, Hegisplatz 6, 7000 Chur, Switzerland, June 1980 

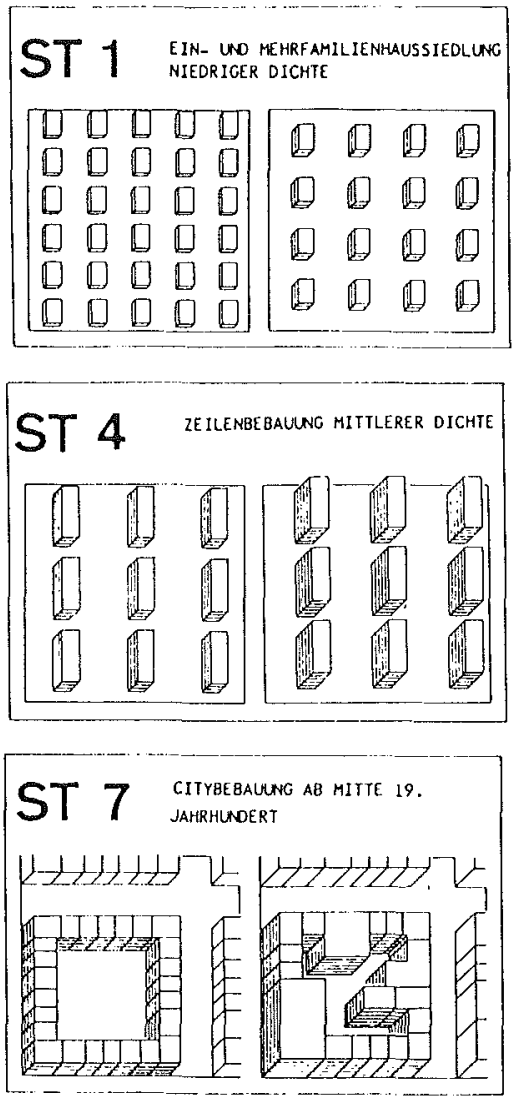
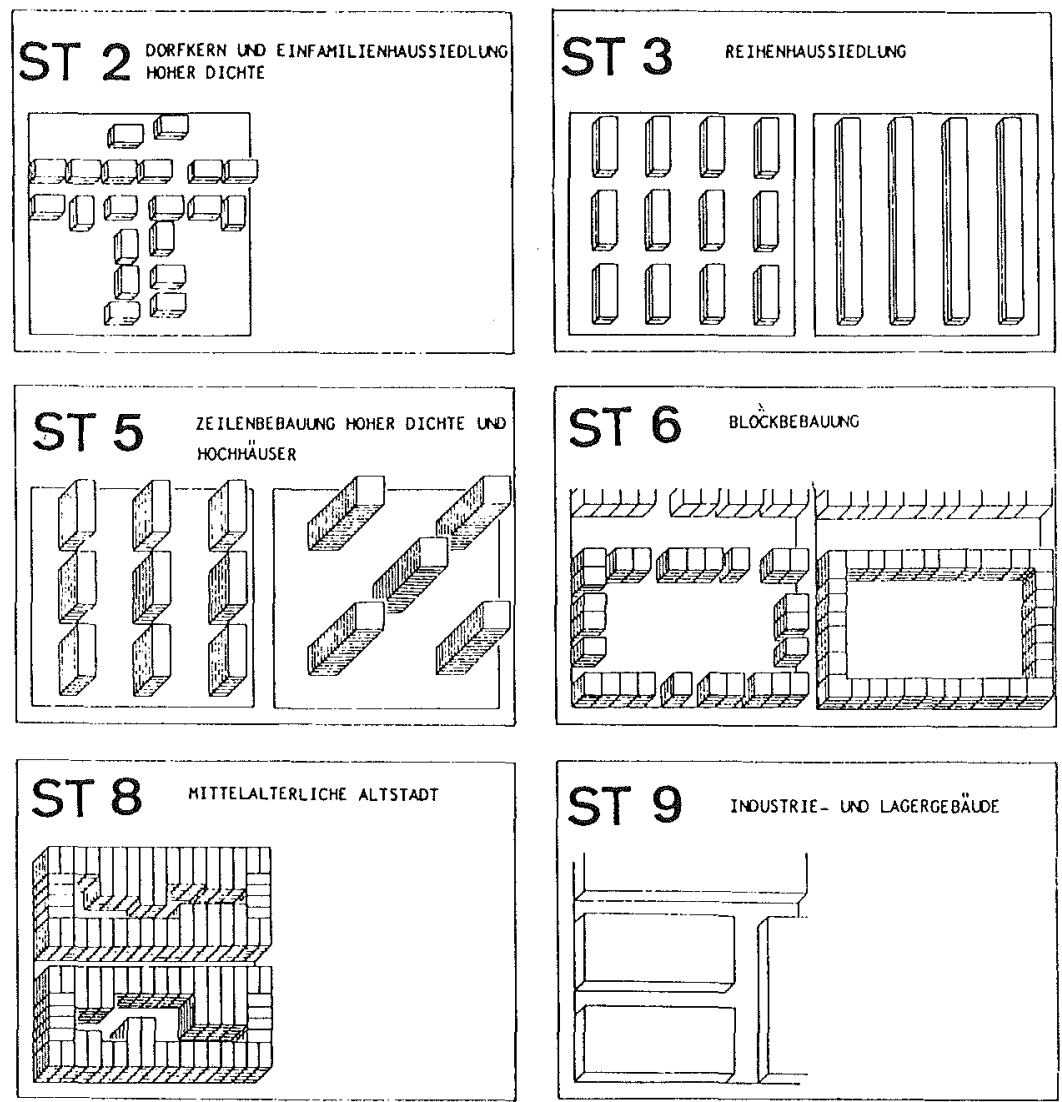

ST 9 industrie- Wo LaGergebäLoe

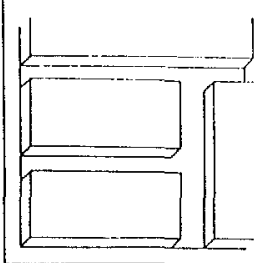

\subsection{SETTLEMENT PATTERN AND HEATING OPTIMIZATION}

\section{BACKGROUND}

The implications of the physical characteristics of urban structure on space heating has been researched in the Federal Republic of Germany since the mid seventies. As the result of a competition the Swiss consulting firm 'UR' of Ueli Roth (Zürich) was awarded the project described here. Heating systems of various types and scales were evaluated for their economic and energy performance potential for given configurations of settlements. Domestic water heating as well as space heating were considered. 


\section{Objectives}

- Devise an analytical procedure for minimizing space heating and water heating costs (including conservation investment and operating costs) given the implications of specified settlement structures.

- Assess individual consumer goals and their compatibility with regional energy goals.

\section{Approach}

A cost benefit analysis method was used to analyze various combinations of residential settlement patterns and heat supply systems. Each such combination was analyzed relative to conservation (insulation) investment costs and respective heat supply costs (energy, operation, maintenance, and capital). Figure 10 illustrates the principle of determining a total cost minimum.

Annual cost

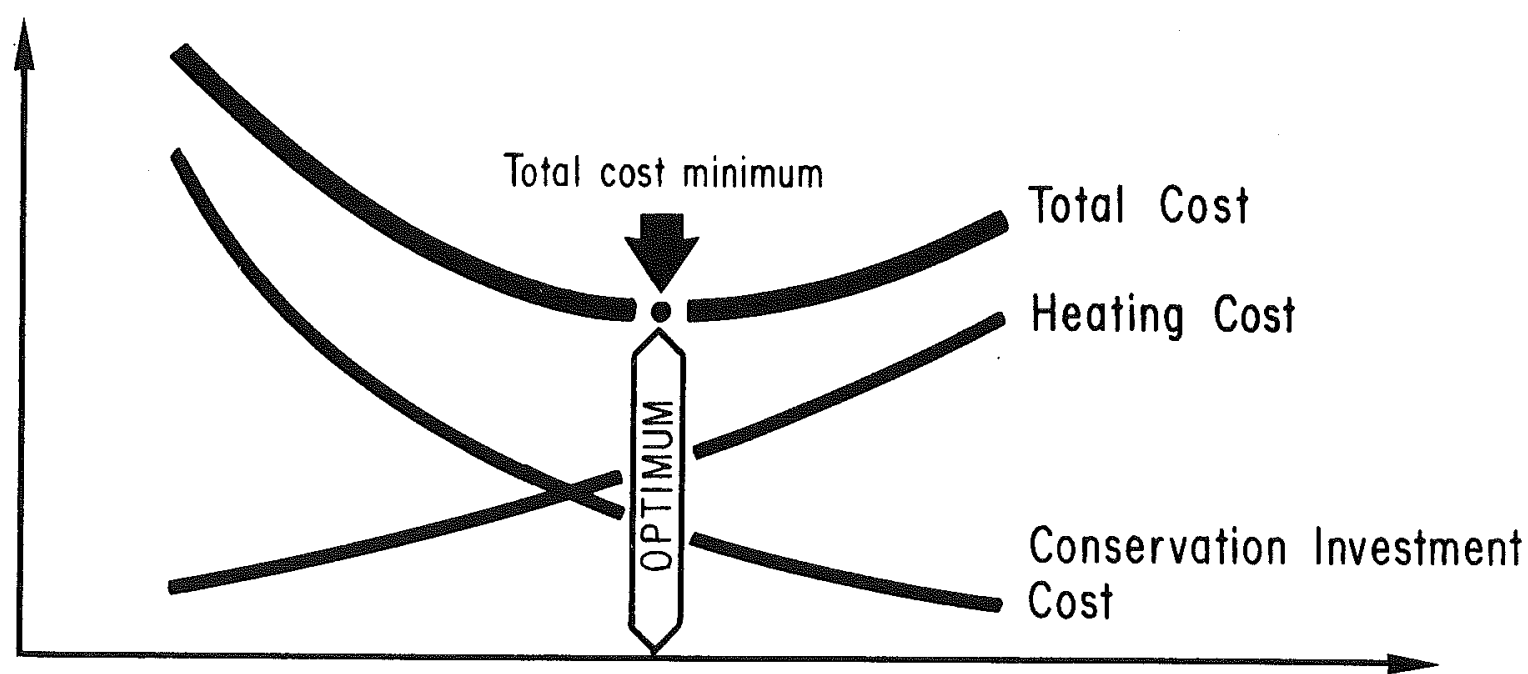

Fig. 10 Total Cost Minimization 
The approach to the project had four steps:

1. Definition of various building and settlement configurations (including both present and possible future configurations).

2. Cost analyses of various heating conservations options.

3. Cost analyses of various heat supply systems.

4. Evaluation of various heat supply systems relative to items 1,2 , and 3 above.

Each of these steps will now be discussed.

1. Settlement pattern

Nine settlement types were defined as bases for the calculations. The types were derived in consideration of several (unstated) data bases for German cities and towns.

2. Heat conservation in buildings

Heat conservation is often capital intensive. A major issue is therefore how to use available capital with maximal efficiency. First the costbenefit characteristics of a single conservation alternative have to be represented. Two main conservation alternatives considered were:

a) Insulation improvement for the nontransparent parts of the she11 (walls, roofs, etc.)

b) Window improvements.

A representative catalogue of heat conservation alternatives was assembled to show their cost relative to gained insulative values. Economically optimal solutions were identified from various combinations of measures.

3. Heat supply systems

Twelve heating system types were compared. Their capital cost and operational cost were evaluated relative to saved heat. 
4. Evaluation of heat supply systems

The effectiveness of certain heating systems for given settlement patterns can be evaluated based on average combined costs for heating supply and conservation. Figure 11 illustrates a ranking of different heat supply systems for different settlement patterns. The number of dots indicates the goodness of the match between the heating system and the settlement pattern. 
Old Construction

New Construction

Key

- Minimal match

- Good match

$\cdots$ Excellent match

\begin{tabular}{|c|c|c|c|c|c|c|c|c|c|c|c|c|c|c|}
\hline & 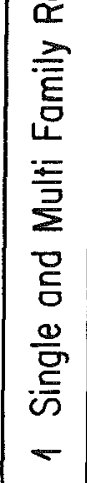 & 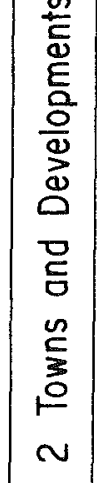 & | & 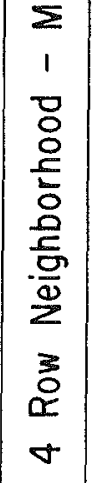 & 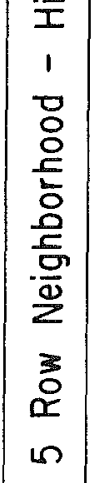 & 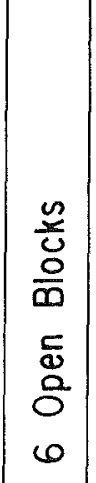 & 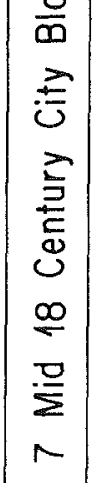 & 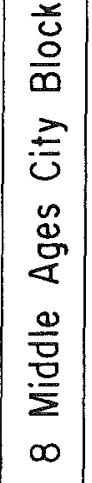 & $\begin{array}{l}\text { 롬 } \\
\text { 吾 } \\
\underline{5} \\
0\end{array}$ & 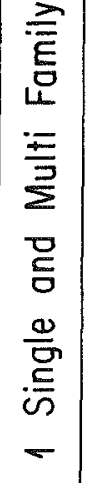 & 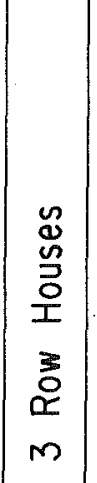 & 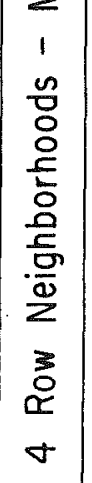 & 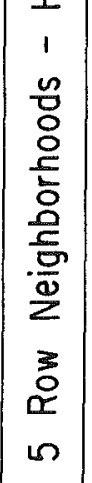 & $\begin{array}{l}\text { 辛 } \\
\text { 咅 } \\
\text { c } \\
\text { o }\end{array}$ \\
\hline & $\begin{array}{c}\text { ST } \\
1 \\
\end{array}$ & \begin{tabular}{|c} 
ST \\
2 \\
\end{tabular} & $\begin{array}{c}\text { ST } \\
3 \\
\end{array}$ & \begin{tabular}{|c|} 
ST \\
4 \\
\end{tabular} & $\begin{array}{c}\text { ST } \\
5 \\
\end{array}$ & \begin{tabular}{|c|}
$S T$ \\
6 \\
\end{tabular} & \begin{tabular}{|c|} 
ST \\
\\
\end{tabular} & \begin{tabular}{|c|}
$S T$ \\
8 \\
\end{tabular} & $\begin{array}{c}\text { ST } \\
9 \\
\end{array}$ & $\begin{array}{c}\text { ST } \\
1 \\
\end{array}$ & $\begin{array}{c}\mathrm{ST} \\
3 \\
\end{array}$ & $\begin{array}{c}\text { ST } \\
4 \\
\end{array}$ & \begin{tabular}{|c|}
$S T$ \\
5 \\
\end{tabular} & $\begin{array}{c}\text { ST } \\
9 \\
\end{array}$ \\
\hline District Heating System & $\bullet$ & $\bullet$ & $\bullet$ & 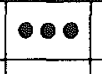 & $\infty$ & $\Leftrightarrow$ & $\infty$ & $\cdots$ & $\bullet$ & $\cdots$ & $\because$ & $\cdots$ & $\cdots$ & $\bullet$ \\
\hline Annual Solar System & - & - & $\bullet$ & $\bullet$ & - & - & -1 & - & - & - & $\bullet$ & - & - & $\cdot$ \\
\hline Solar Ast Central System & - & - & - & - & $\bullet$ & - & - & - & - & $\bullet$ & $\bullet$ & - & - & - \\
\hline Wood Fired Boiler & - & - & - & - & - & - & - & - & - & $\bullet$ & $\bullet$ & - & - & - \\
\hline Cogeneration System & $\cdots$ & $\cdots$ & $\cdots$ & $\cdots$ & $\infty$ & $\ldots$ & $\ldots$ & $\cdots$ & $\cdots$ & $\cdots$ & $\bullet$ & $\cdots$ & $\cdots$ & $\bullet$ \\
\hline Gas Heat Pump & - & $\bullet$ & $\bullet$ & $\bullet$ & $\bullet$ & 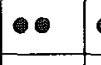 & $\bullet$ & $\bullet$ & $\bullet$ & $\bullet$ & $\bullet$ & $\bullet$ & $\bullet$ & 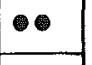 \\
\hline Gas Furnace & $\bullet$ & $\bullet$ & $\bullet$ & $\bullet$ & $\bullet$ & $\bullet$ & $\bullet$ & $\bullet$ & $\bullet$ & $\cdots$ & $\bullet \bullet$ & $\bullet$ & $\bullet$ & $\bullet$ \\
\hline Oil Furnace & $\bullet \bullet$ & $\cdot$ & $\bullet$ & - & - & - & - & - & $\bullet$ & $\cdots$ & $\bullet$ & - & - & $\cdot$ \\
\hline Electric / Heat Storage & $\bullet$ & - & - & - & - & $\cdot$ & - & $\cdot$ & - & $\cdots$ & - & - & - & - \\
\hline Heat Pump & $\cdots$ & - & $\bullet$ & - & $\bullet$ & $\bullet$ & - & - & - & $\cdots$ & - & - & - & - \\
\hline Oil / Solar & $\cdot$ & - & $\bullet$ & - & - & - & - & - & - & - & - & - & - & - \\
\hline Biogas & - & - & - & - & - & & & & & & $\bullet$ & • & & \\
\hline
\end{tabular}

Fig. 11 Urban Structure versus Heating System Types 


\section{Status}

On grounds of this theoretical study the firm 'ur' has been asked by the federal government to conduct several case studies in different German towns. Regional heat-supply-concepts for Hamburg and for Mannheim/Heidelberg will be developed during the period of 1981 - 1983 .

\section{Example Results}

The investment cost of economical heat conservation measures for new and existing buildings would be circa $\$ 20$ to 30 billion (1978 dollars) for Germany over 20 - 30 years. With a 25 percent increase in heated floor area the heat load could be decreased by 15 percent from the current heat load by these measures.

The report stresses that a shift in investment from macrotechnological energy supply systems to smaller scale retrofit conservation systems is economical and ecologically more apropriate.

\section{Comments}

The main achievement of the project is a classification and quantification of the interdependencies between urban structure and energy supply systems. This approach could well be used in case studies. However, one should not perceive this report to be a guide for selecting a heating system for a given settlement. In practice this decision will depend on more variables than those included in the report's analysis, such as availability of a given system on the market or how secure the delivery of a given fuel type will be in the future. Also, the scenarios for different energy price developements were too limited. Oil prices have a1ready exceeded the levels assumed in price escalation calculations. 
A final comment must be made that passive use of solar energy could also be treated as a means of energy supply in combination with conservation. THis has been treated only in a cursory manner.

\section{Publications}

1. Schweizerisches Status-Seminar "Wärmeschutzforschung im Hochbau", EMPA, 8600 Dïbendorf, October 1980.

2. "The Impact of Settlement Patterns on Low Temperature Heating Supply Systems, Transportation and Environment",

Proceedings of the International Congress for Energy

Supply and Management, Tucson, Arizona, USA.

Pergamon Press, 1977.

3. "Wechselwirkung zwischen Siedlungsstruktur und Wärmeversorgungssystem" (mit F. Häubi). Schweizer Ingenieur und Architekt, Nr. 29/1980, SIA, 8039 Zürich. 


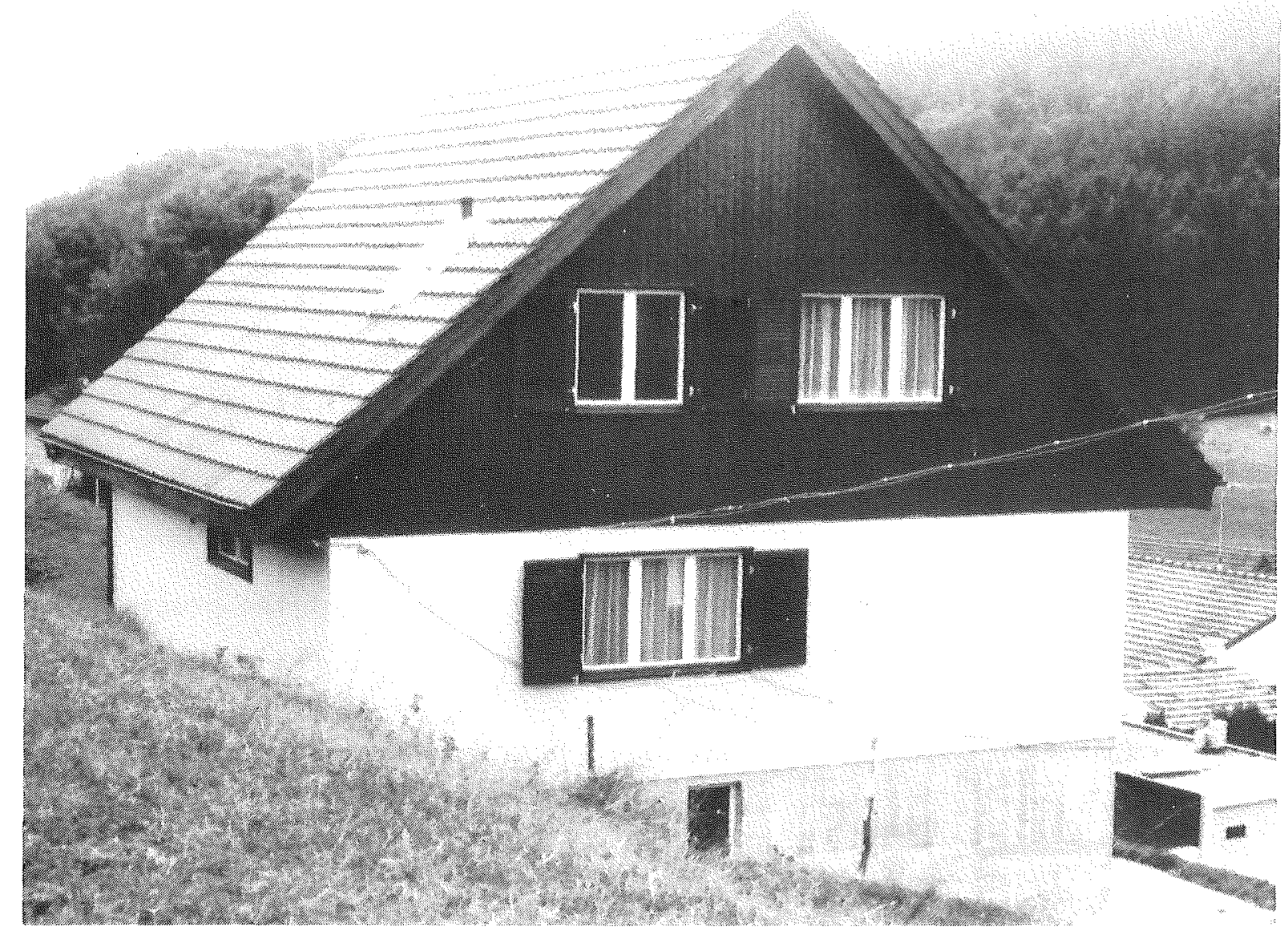

\subsection{DOE 2. IMPLEMENTATION AND VALIDATION}

\section{BACKGROUND}

A building energy use computer model, DOE 2 (U.S. Dept of Energy) is being validated for use in Switzerland by the EMPA. The work is being carried out as part of the International Energy Agency (IEA) Program, "Energy Conservation in Buildings and Community Systems" (under Annexes I, III and IV). Dr. J. Gass of EMPA is the project leader for a set of test runs using DOE 2 : an English bank office building in Bristol (analyses completed); an English commercial office building in Glasgow (in progress); a Swiss single family house in Maugwil (in progress, see photo above); and a Swiss apartment building in Lausanne (in progress). 


\section{Objectives}

- Evaluate a computer program, DOE 2, for analyzing the energy and economic performance of buildings.

- Compare DOE 2 results with measured data from instrumented buildings.

- Customize DOE 2 for specific Swiss requirements (e.g. Swiss building practices, HVAC equipment, and climate data format).

\section{Approach}

For those readers not familiar with the details of the program, a description follows. DOE 2 is a program which calculates the hour-by-hour energy use of a building and its life-cycle cost of operation, given information on the building's location, construction, operation and HVAC equipment.

The program has four main calculation sections:

Loads: Calculates hourly heating and cooling loads for each designated space (thermal zones) within the building.

Systems: Simulates the operation of the heating and cooling distribution system, taking into account outside air requirements, operating and control schedules, and building transient response when no heating or cooling is required.

Plant: Simulates the operation of primary energy conversion equipment. The program models:

a) conventional central plants

b) solar heating and cooling systems

c) plants with on-site heat generation and waste heat recovery. Monthly and annual costs are calculated. 
Economics: Calculates the present value of the life-cycle cost of the building, including cost of fuel, equipment, operation and maintenance.

Input data include:

General: Building location, weather data.

Loads: Building orientation, dimensions, materials etc.

System: HVAC description.

Plant: Primary equipment.

Economics: First cost, replacement costs, annual costs for non plant items.

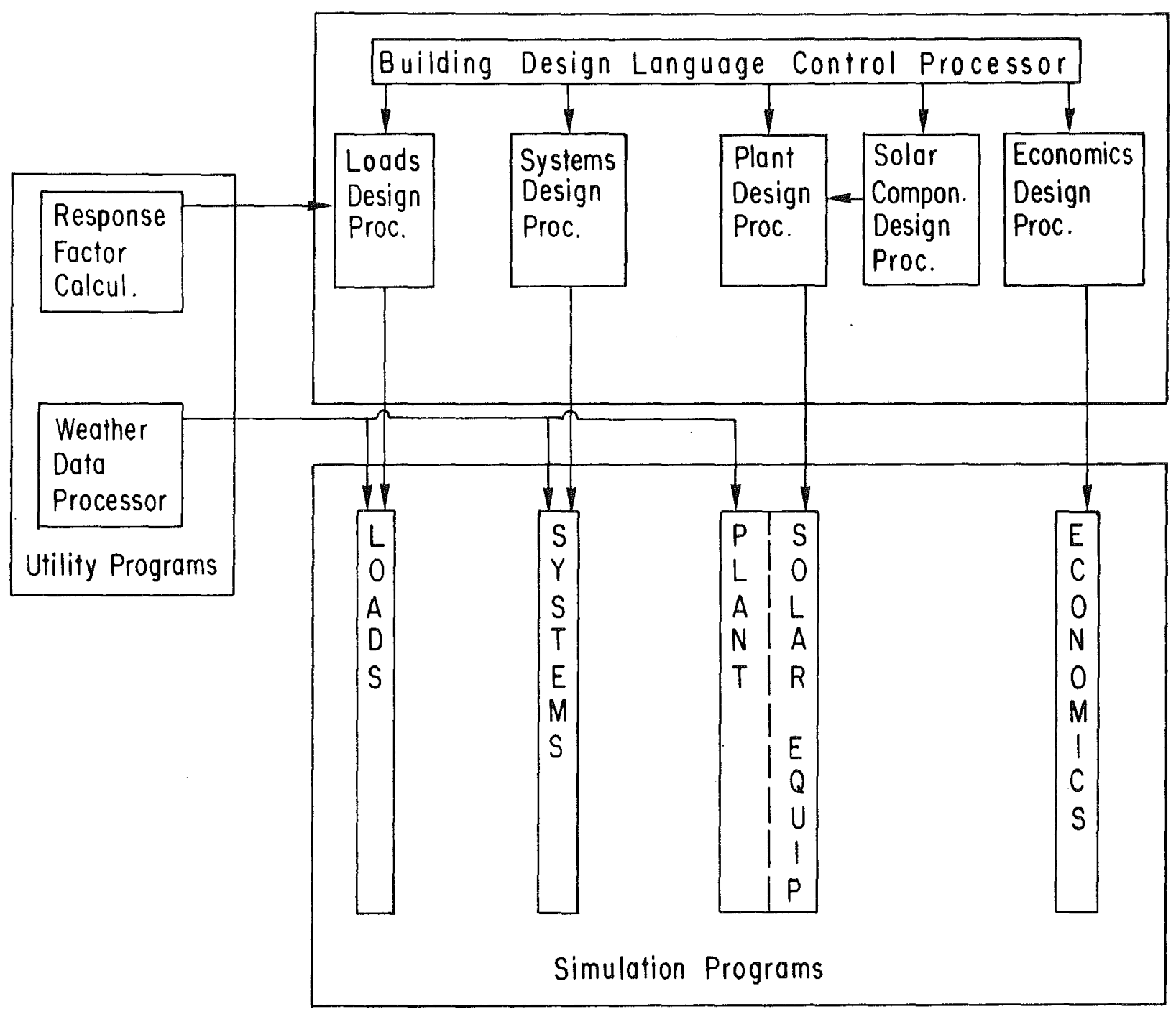

Fig. 12 Doe 2 Computer Program Configuration 
At the beginning of the project the only available long term hourly weather data which included solar radiation data, were from Zürich's Kloten airport ( 8 years: 1964 - 1972). However, the Kloten climate is not typical for all of Switzerland The Swiss Meteorological Institute SMA began installation of an automatic net of 60 weather stations (ANETZ) in 1978. As the ANETZ hourly measurement computer files become available they will be the main source for preparing DOE 2 weather files. However, the present two years of data are not enough to produce a representative average year weather file. In order to get reliable results on the life cycle energy cost of buildings with DOE 2 the ANETZ data will have to be complemented by long term weather data.

Another problem is obtaining direct normal radiation data, which is currently not measured and has to be derived from global horizontal radiation data.

\section{Status}

Following analyses of a hypothetical American office building in a Swiss climate DOE 2 was tested on a bank building in Bristol, England. The test on the Glasgow commercial building is in progress. Selected Swiss climate data can now be entered in DOE 2. Analysis of the Lausanne apartment block and comparison with measured date from the building is now underway.

\section{Example Results}

The following table is output from a DOE analysis of the above mentioned American office building modeled with Swiss climate data (Kloten). It is an open plan, single story building $15 \times 30 \mathrm{~m}$ long, divided in the program into five thermal zones. Windows are double glazed, walls have an insulation value of $0.4 \mathrm{~W} / \mathrm{m}^{2}$, and the roof and floor $0.3 \mathrm{~W} / \mathrm{m}^{2}$. 


\section{Table 1}

Example Building 3A, Kloten

Report-SS-D Plant Monthly Loads Summary for Conventional

\begin{tabular}{|c|c|c|c|c|c|c|c|c|c|c|c|c|c|c|}
\hline \multirow{3}{*}{ Month } & \multicolumn{7}{|c|}{$\mathrm{C} \circ \circ \mathrm{O}$ i $\mathrm{ng}$} & \multicolumn{5}{|c|}{$\mathrm{H} \in \mathrm{a} t i \mathrm{n} g$} & \multicolumn{2}{|c|}{$E 1$ e $c$} \\
\hline & \multirow{2}{*}{$\begin{array}{l}\text { Cooling } \\
\text { Energy } \\
\text { (MBTU) }\end{array}$} & \multicolumn{2}{|c|}{ Time } & \multirow{2}{*}{$\begin{array}{l}\text { Dry- } \\
\text { Bulb } \\
\text { Temp }\end{array}$} & \multirow{2}{*}{$\begin{array}{l}\text { Wet- } \\
\text { Bulb } \\
\text { Temp }\end{array}$} & \multirow{2}{*}{$\begin{array}{l}\text { Maximum } \\
\text { Cooling } \\
\text { Load } \\
(\mathrm{KBTU} / \mathrm{HR})\end{array}$} & \multirow{2}{*}{$\begin{array}{l}\text { Heating } \\
\text { Energy } \\
\text { (MBTU) }\end{array}$} & \multicolumn{2}{|r|}{ Time } & \multirow{2}{*}{$\begin{array}{l}\text { Dry- } \\
\text { Bulb } \\
\text { Temp }\end{array}$} & \multirow{2}{*}{$\begin{array}{l}\text { Wet- } \\
\text { Bulb } \\
\text { Temp }\end{array}$} & \multirow{2}{*}{$\begin{array}{l}\text { Maximum } \\
\text { Heating } \\
\text { Load } \\
(\mathrm{KBTU} / \mathrm{HR})\end{array}$} & \multirow{2}{*}{$\begin{array}{l}\text { Elec- } \\
\text { trical } \\
\text { Energy } \\
(\mathrm{kWh})\end{array}$} & \multirow{2}{*}{$\begin{array}{l}\text { Maximum } \\
\text { Elec } \\
\text { Load } \\
(\mathrm{kW})\end{array}$} \\
\hline & & $\begin{array}{l}\text { of } \\
d y\end{array}$ & $\begin{array}{l}\max \\
\mathrm{hr}\end{array}$ & & & & & $\begin{array}{l}o f \\
d y\end{array}$ & $\begin{array}{l}\max \\
\mathrm{hr}\end{array}$ & & & & & \\
\hline Jan & 3.053 & 30 & 18 & $46 \mathrm{~F}$ & $40 \mathrm{~F}$ & 42.01 & 13.945 & 14 & 9 & $5 \mathrm{~F}$ & $5 \mathrm{~F}$ & 377.54 & 5.316. & 20. \\
\hline Feb & 9.299 & 27 & 18 & $59 \mathrm{~F}$ & $48 \mathrm{~F}$ & 66.22 & 4.142 & 18 & 9 & $43 \mathrm{~F}$ & $42 \mathrm{~F}$ & 261.14 & 4.739 & 21. \\
\hline Mar & 10.300 & 22 & 18 & $55 \mathrm{~F}$ & $43 \mathrm{~F}$ & 68.44 & 3.669 & 25 & 9 & $32 \mathrm{~F}$ & $31 \mathrm{~F}$ & 160.19 & 5.051 & 21. \\
\hline Apr & 12.001 & 5 & 17 & $64 \mathrm{~F}$ & $48 \mathrm{~F}$ & 92.65 & -.404 & 22 & 9 & $36 \mathrm{~F}$ & $36 \mathrm{~F}$ & 165.30 & 5.158. & 21. \\
\hline May & 20.377 & 16 & 9 & $63 \mathrm{~F}$ & $56 \mathrm{~F}$ & 184.10 & -.010 & 7 & 9 & $43 \mathrm{~F}$ & $42 \mathrm{~F}$ & 9.88 & 5.428. & 21. \\
\hline Jun & 25.109 & 17 & 9 & $73 \mathrm{~F}$ & $63 \mathrm{~F}$ & 296.85 & 0.000 & & & & & 0.00 & 4.856 & 21. \\
\hline JuI & 24.762 & 5 & 9 & $70 \mathrm{~F}$ & $64 \mathrm{~F}$ & 231.83 & 0.000 & 24 & 11 & $59 \mathrm{~F}$ & $58 \mathrm{~F}$ & 0.25 & 5.436 & 21. \\
\hline Aug & 22.754 & 12 & 9 & $68 \mathrm{~F}$ & $64 \mathrm{~F}$ & 272.76 & 0.013 & 21 & 9 & $61 \mathrm{~F}$ & $60 \mathrm{~F}$ & 4.76 & 5.251 & 21. \\
\hline Sep & 21.203 & 9 & 9 & $70 \mathrm{~F}$ & $65 \mathrm{~F}$ & 269.61 & 0.030 & 12 & 10 & $61 \mathrm{~F}$ & $61 \mathrm{~F}$ & 6.96 & 5.031 & 21. \\
\hline Oct & 15.300 & 7 & 9 & $57 \mathrm{~F}$ & $56 \mathrm{~F}$ & 186.71 & 0.851 & 28 & 9 & $41 F$ & $40 F$ & 183.99 & 5.377 & 21. \\
\hline Nov & 5.152 & 7 & 16 & $55 F$ & $49 \mathrm{~F}$ & 61.91 & 5.748 & 18 & 9 & $34 \mathrm{~F}$ & $33 \mathrm{~F}$ & 316.72 & 4.966 & 20. \\
\hline Dec & 3.107 & 19 & 18 & $43 \mathrm{~F}$ & $39 \mathrm{~F}$ & 29.15 & 9.522 & 9 & 9 & $34 \mathrm{~F}$ & $33 \mathrm{~F}$ & 373.36 & 5.145 & 20. \\
\hline Total & 172.422 & & & & & & 58.333 & & & & & & 61.750 & \\
\hline $\operatorname{Max}$ & & & & & & 296.85 & & & & & & 373.54 & & 21. \\
\hline
\end{tabular}




\section{Comments}

The DOE 2 program is now operational in Switzerland. Such a program is a very useful tool in designing large buildings with complex mechanical systems. It is also an important means of creating data to increase awareness of the possibilities for energy conservation. New and unconventional designs can be tested for their benefit and feasability. DOE 2 together with other programs, such as DEROB (see the next project description), form a comprehensive package for computer aided design of low energy and passive solar architecture. The running cost and labor required in using such programs limit their use to complex, expensive buildings or as a research tool, however.

DOE 2 maintenance and development require the continuous effort of a staff expert in the particular computer system being used, in building physics, and in building mechanical system design practices in Switzerland. Because of the skill and costs involved, it appears logical to develop a central DOE 2 users' resource center for Switzerland where such work is conducted and maintenance and development costs are shared over a broad base of program users. 


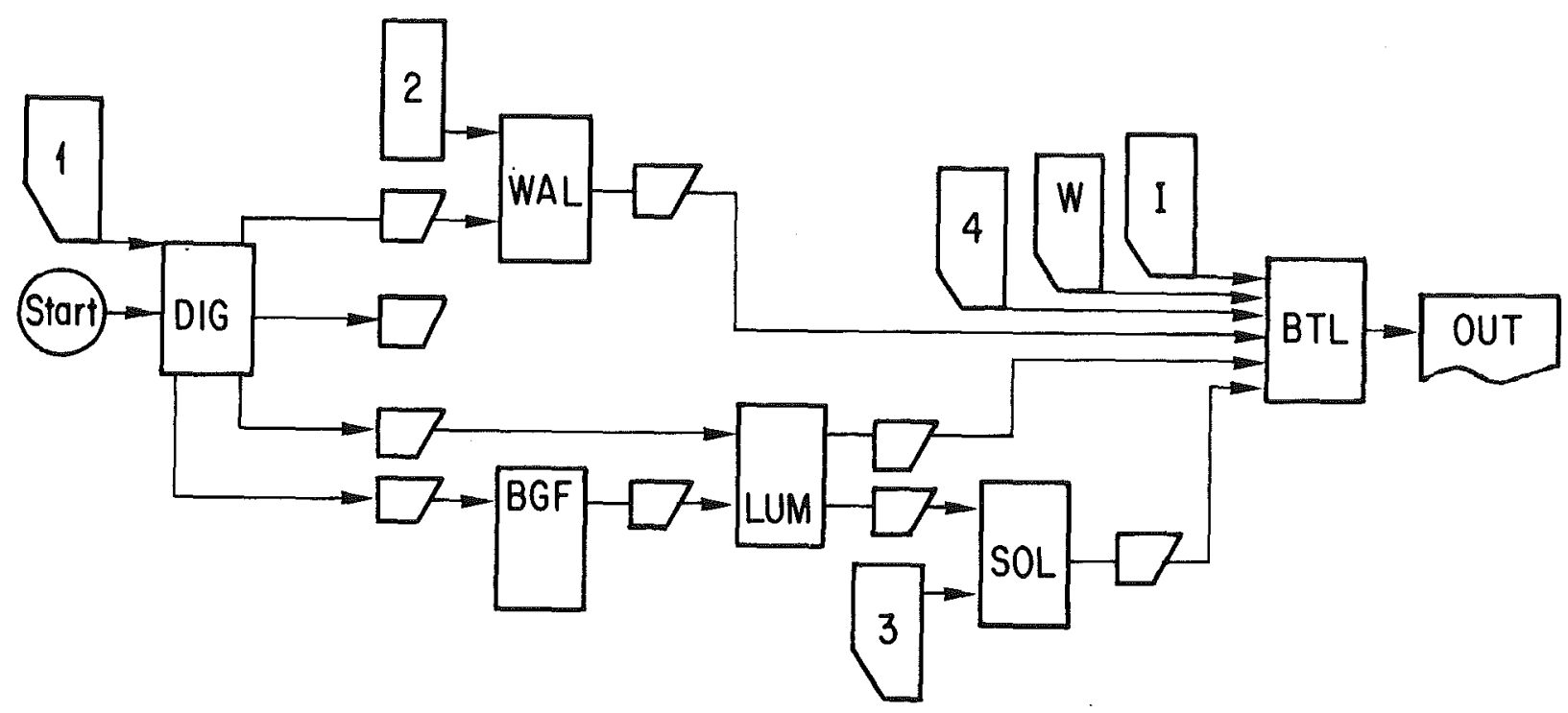

\subsection{DEROB IMPLEMENTATION AND VALIDATION}

\section{BACKGROUND}

The computer program DEROB (Dynamic Energy Response of Buildings), written by $F$. Arumi at the University of Texas at Austin has been installed and checked against a test cabin in Maugwil (Direct Gain). The principal investigators for the project are $S$. Robert Hastings of EMPA and $K$. Schenker of the ETHZ. Modifications were made to simplify use of the program and a new user's manual was written in German. The first application of the program was a parametric study of attached greenhouses under Zürich climate conditions. The results of the study and comments on the program have been published. 


\section{Objectives}

- Install DEROB on the ETH computer to provide a rigorous, hourly simulation program for analyzing passive solar design approaches.

- Validate the program to assure that modifications required during installation did not alter the logic of the program.

- Write a user's guide in German, documenting the input, output, and capabilities of the program plus changes made to the program to simplify its use.

- Conduct a parametric study to assess the capabilities of the program.

\section{Approach}

The program was installed on a CDC CYBER 175 computer. Installation required a number of changes of both a compiler error nature and of a program execution nature.

After the program was installed a simple direct gain test cell (Maugwil) with detailed measured temperature and energy use data was simulated and the results compared to the measured data. After this initial simulation work a number of desired input/output formats, and built-in constants were changed to facilitate use of the program.

Finally, a parametric study was run on the heating and temperature performance of an attached greenhouse to assess the capabilities of the program as a research tool.

\section{Status}

The program is now operational on the ETH main computer. Documentation has been completed. The initial validation of the installation is completed. A number of input/output simplifications have been completed. The greenhouse parametric study has been completed. Future work will include updating or new installation of DEROB version 4, adapting SI units if not available on the next version, and further parametric studies with passive solar design approaches. 


\section{Example Results}

Figure 13 illustrates the house used in the case study. Figures 14 and 15 graph temperature and heating loads as a function of one of the parameters studied with DEROB: the number of glazed walls of a greenhouse. A common design question is, "how does the number of glazed walls affect the greenhouse temperature and its ability to reduce house heating requirements?" The graphs illustrate greenhouse performance given climate conditions of Kloten for three mid-winter days. The data indicate that during low insolation, mid-winter periods the less non-south glazing, the better the greenhouse performance.

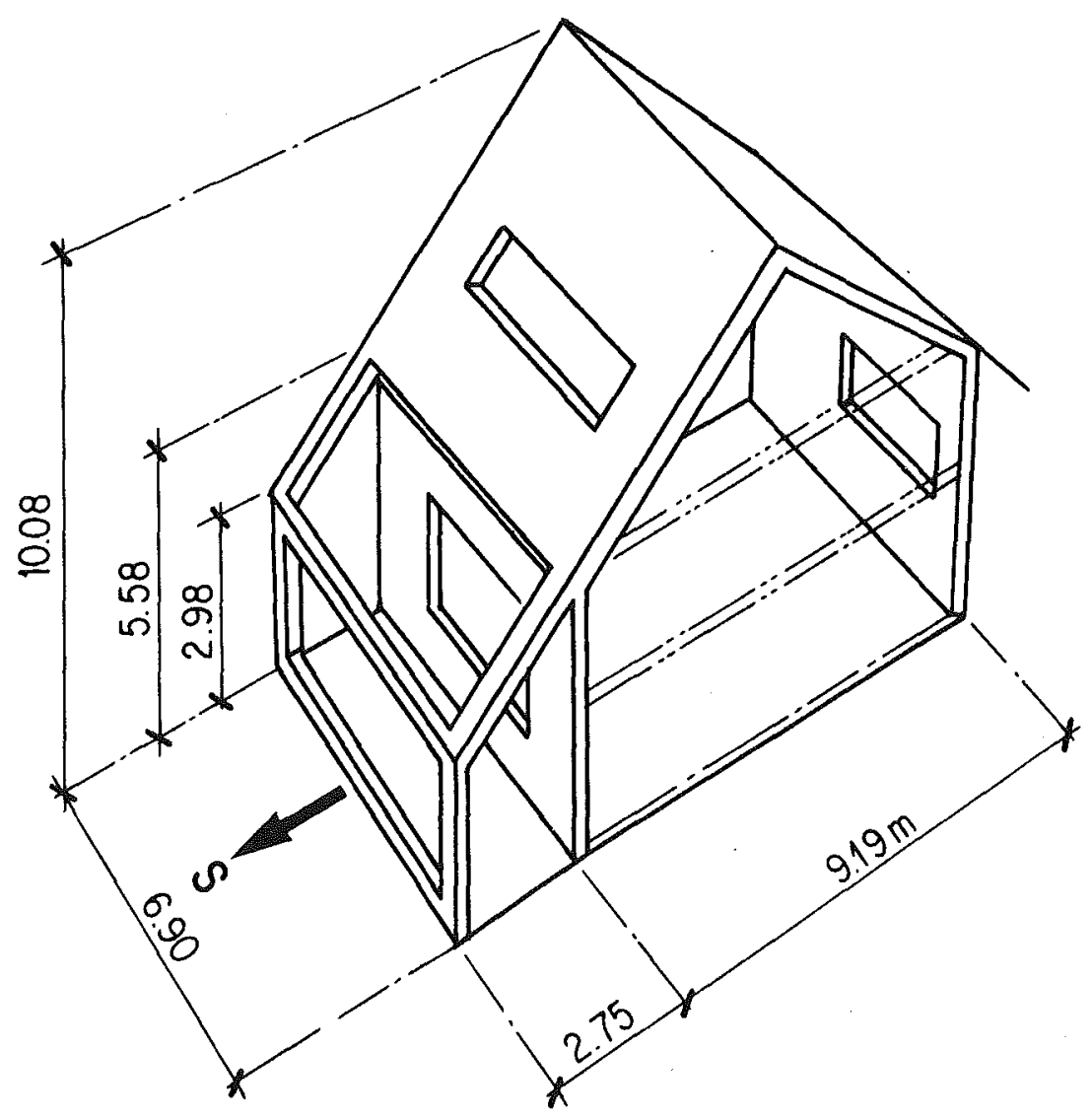

Fig. 13 House geometry 


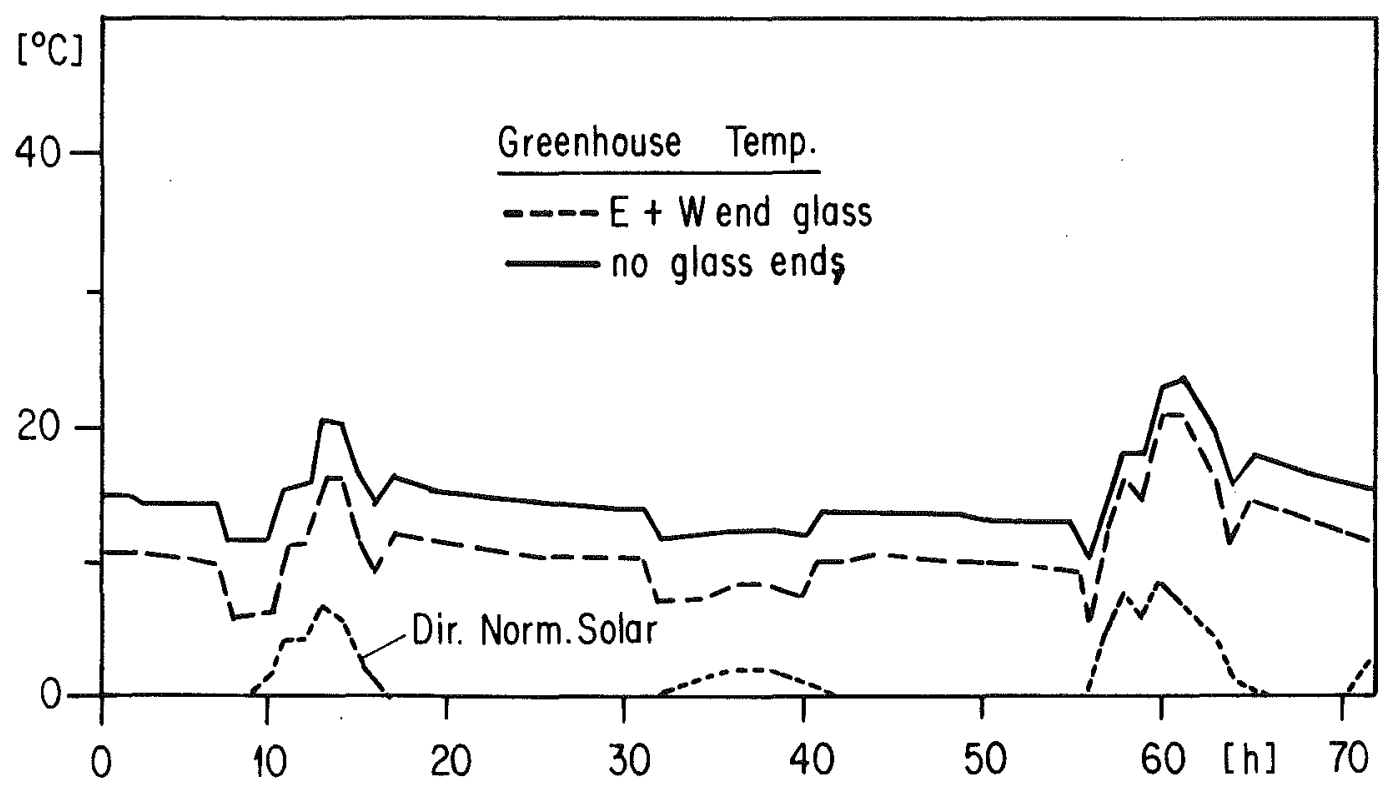

Fig. 14 Greenhouse temp.versus number of glass end walls

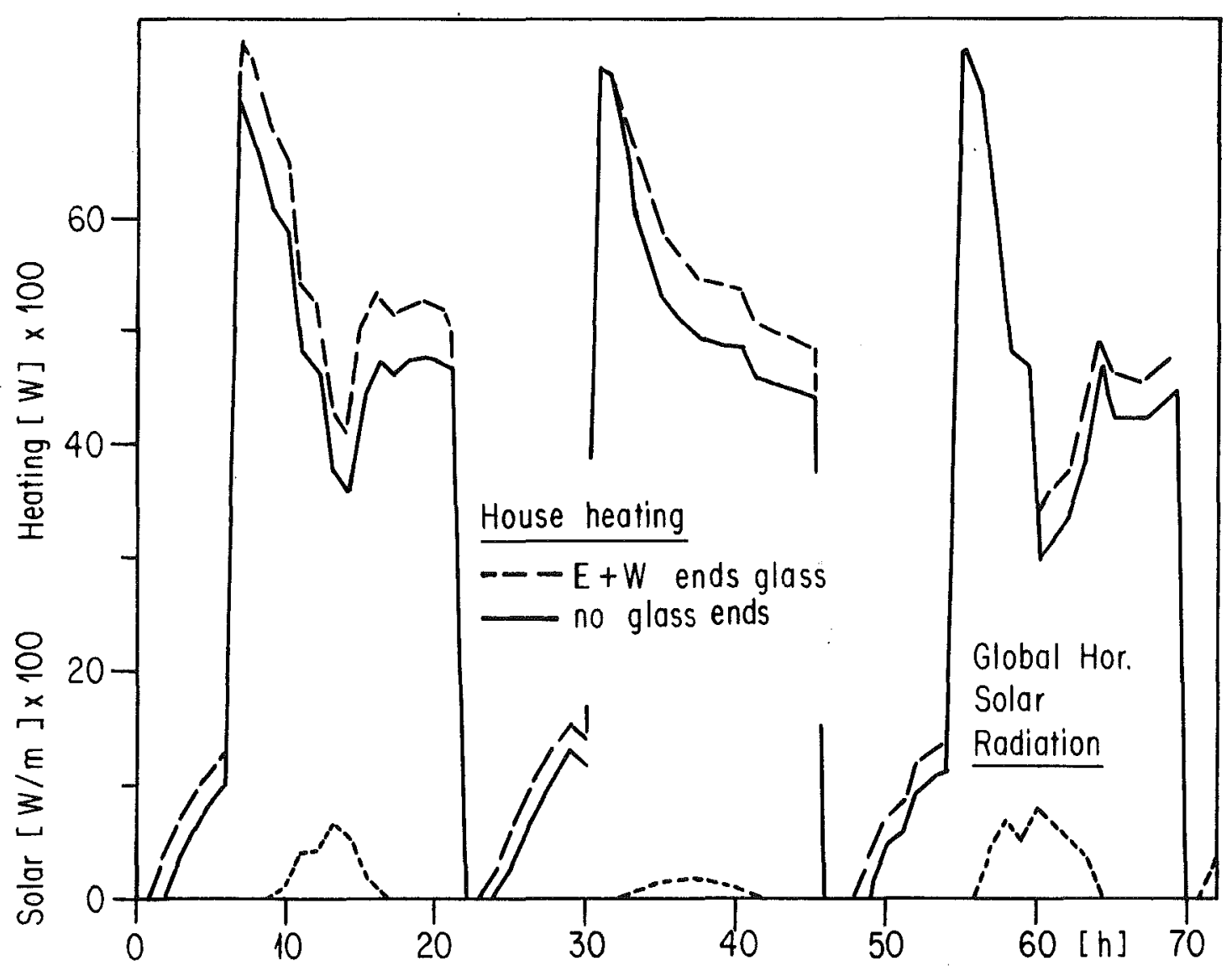

Fig. 15 House heat load versus number of greenhouse glass end walls 


\section{Comments}

DEROB is easier to use than a basic, unenhanced resistance-capacitance network program. The input and output are tailored for building analysis. The program lacks sufficient diagnostics, however. Input is still sufficiently complex that errors are inevitable. Use of the program therefor requires a fairly thorough understanding of some of the program logic in order to diagnose errors.

The validation of the correct installation of the program must not be interpreted as a full scale program validation effort. The exercise demonstrated the sensitivity of input parameters or built-in constants, which in practice are only educated guesses. Examples include the ground reflectivity, the solar absorptivity of surfaces, and the in-place thermal insulation value of materials. By adjusting the initial values of these estimated parameters, an acceptable fit could be achieved between measured and simulated heating demand and temperature profiles of the test cabin. The extent that these revisions reflect reality or compensate for possible inaccuracies of the program can only be determined by an extended validation project. Validation of the program has been done in the U.S. and a good agreement achieved.

Use of the program as a research tool to study the sensitivity of selected design parameters was very satisfactory. The level of detail possible for the output is variable and excellent for studying individual surface temperatures of components. The most serious drawback the program has is the relatively high running costs and execution time required for runs of heating season length. It is expected that the newest version, not yet installed, will execute in one third of the time presently required. 


\section{Publications}

Hastings, S.R., "Analysis of an Attached Greenhouse in a Low Insolation Northern Climate", Proceedings of the Sixth National Passive Solar Conference, American Section of the International Solar Energy Society, Univ. of Delaware, Newark, DW. 19711, 1981.

Schenker, K., DEROB, Eine Anleitung für Benützer, EMPA, Dïbendorf, July 1981 . 


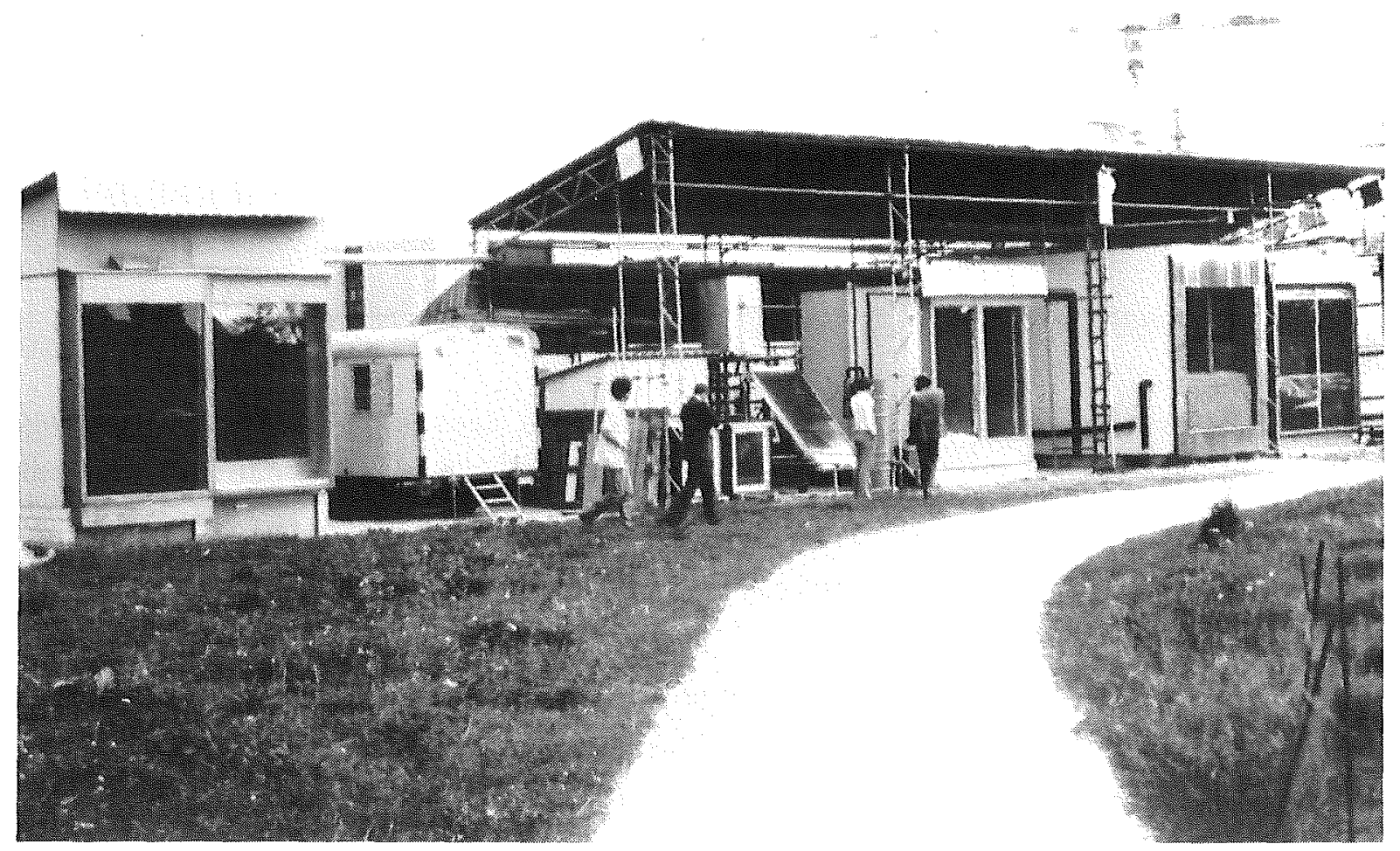

\subsection{STESO TEST CABINS}

\section{BACKGROUND}

The EPFL has built a series of test cabins to measure the performance of different passive solar systems.

At this time seven instrumented test cabins are in service. Each has a replaceable front facade to permit exchanging various passive elements. A comprehensive meteorological station as well as a central automatic data acquisition system are located on the site.

Prof. A. Faist of the Solar Energy Group at the EPFL is the project leader, Dr. J.-B. Gay, Mr. Y. Rey and Mr. C. Eriksson are principal researchers. The project is financed by the EPFL, NF and NEFF. 


\section{Objectives}

- Measure different passive and hybrid solar energy collecting systems under Swiss climatic conditions.

- Validate mathematical models of passive solar systems.

\section{Approach}

A series of passive solar designs have been tested for their performance under Swiss climatic conditions using instrumented test cabins. The cabins have been built side-by-side and share an on-site meteorological station and data acquisition system to facilitate cross comparisons.

The meteorological parameters measured are: global solar radiation on horizontal, S., E., N., and W. orientations; horizontal diffuse and infrared radiation: wind speed and direction; and dry bulb temperature and relative humidity.

The data acquisition system accomodates 120 channels which are measured in intervals ranging from 30 seconds to 30 minutes. The data are stored on magnetic tapes and later analyzed by the department of Physics at the EPFL.

\section{Status}

Seven test cabins have been built and have undergone one or more winters of measurement. The data are now being analyzed to generalize the results to other climates of Switzerland. 


\section{Example Results}

One configuration tested is a mass wall. The wall performed thermally (on a heating season basis) comparable to a base case wall with an insulation value of $0.5 \mathrm{~W} / \mathrm{m}^{2} \mathrm{~K}$. During unfavorable winter periods, (solar gain less than $1.0 \mathrm{kWh} / \mathrm{m}^{2}$ day) a positive energy balance for the mass wall would require both double glazing and a selective absorbing surface.

A free-standing greenhouse was also tested. The configuration was modified from its kit configuration to include opaque rigid insulation on the north wall, north roof, and part of the sides. Water drums were added for thermal mass. A small nodal computer model was then written to analyze the thermal performance of the greenhouse. A relatively good agreement was eventually achieved between measured and computed performance, though the model is tailored specifically for that particular greenhouse.

The dynamic thermal response of various window configurations was tested in several direct gain test cabnis. The tested configurations included selective transmittance glazing, moveable night insulation, bead wall, and single, double and triple glazing. The experimenters concluded that in the local climate, double glazing compared to single glazing would save $160 \mathrm{kWh} / \mathrm{m}^{2}$ and that double glazing with a selective surface could save an additional $90 \mathrm{kWh} / \mathrm{m}^{2}$ over the course of one heating season. Table 2 provides statistics on five of the test cabins.

Table 2 Swiss Test Cabins Statistics

$\begin{array}{lcccc}\text { Description of cabin } & \begin{array}{r}\text { Volume } \\ \left(\mathrm{m}^{3}\right)\end{array} & \begin{array}{c}\text { Aperture } \\ \left(\mathrm{m}^{2}\right)\end{array} & \begin{array}{c}\text { Capacity } \\ (\mathrm{MJ} / \mathrm{K})\end{array} & \begin{array}{c}\text { Loss } \\ (\mathrm{W} / \mathrm{K})\end{array} \\ \text { Low mass + IR glass } & 12.2 & 5 & 0.7 & 5.2 \\ \text { Low mass + Trombe Wal1 } & 12.2 & 5 & 1.0 & 5.2 \\ \text { High mass + } \mathrm{H}_{2} \text { O Wall } & 30.0 & 6.6 & 17.3 & 21.5 \\ \text { High mass direct gain } & 10.4 & 2.3 & 4.4 & 12.5 \\ \text { Greenhouse + } \mathrm{H}_{2} \text { O stor. } & 6.7 & 9.5 & 4.2 & 8.6\end{array}$




\section{Comments}

The test cells at Lausanne have been an important step in the development of passive solar research. Their usefulness is twofold: to demonstrate the performance of various passive solar elements under local conditions, and to provide immediate data from relatively simple cases to validate mathematical models. The LESO structure, reported later in this document, is a next generation set of test cells.

\section{Publications}

1. J.-B. Gay, A. Faist, "Dynamic Heat Balance of Windows", Pergamon Press Ltd., London; International Conference on Building Energy Management, Porto, Portugal, May 1980

2. N. Morel, A. Faist, "Thermocirculation in solar installations Computer simulation and comparison with measurements" Pergamon Press Ltd - London (International Conference on Building Energy Management, Porto, Portugal, May 1980

3. S. Al-Jrab, G.-R. Perrin, "Mesures de rayonnement infra-rouge et estimation des pertes par rayonnement vers la voûte céleste" Compte-rendu du 2ème Symposium Solaire EPFL, Section A, Lausanne, October 1980 


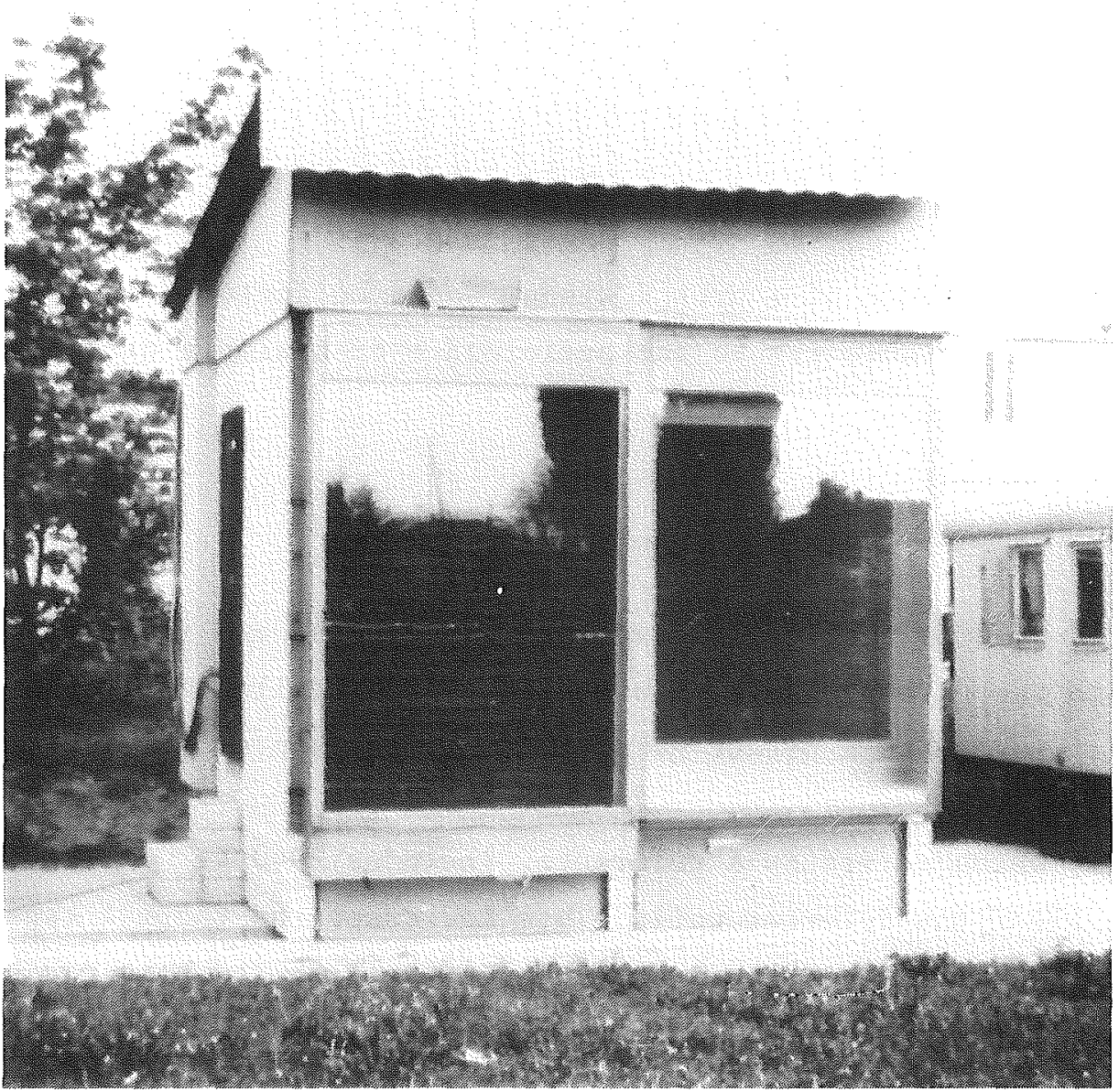

\subsection{SOLAR TRAP}

\section{BACKGROUND}

A hybrid* passive solar concept has been tested in a specially constructed test module and a house using the tested concept has been built. The concept addresses the problem that direct solar gain may be impeded by occupants shading windows to reduce glare or overheating. The "solar trap" concept employs a solar absorber blind lowered between the outer and inner glazing of a window. Sun-heated air is then extracted from the glazing space and circulated either to the room or to thermal storage. When direct gain is not objectionable to the occupant, the blind can be raised and full sunlight admitted into the space. The project was lead by Dr. C. Filleux of Basler \& Hofmann, Engineers in Zürich. Instrumentation and data collection were conducted by EPFL.

*A passive system augmented by a small circulating fan or pump. 


\section{Objectives}

- Measure the performance of a hybrid window solar collector, with rockbed thermal storage relative to the performance of a simple direct gain massive configuration.

\section{Approach}

Two $15 \mathrm{~m}^{3}$ side-by-side test cells have been constructed and instrumented to evaluate the effectiveness of a hybrid, window collector, rock bed storage approach and a direct gain, thermal mass approach.

The mass cell, which serves as a reference, includes $3040 \mathrm{~kg}$ of brick on the floor and interior walls. This increases the thermal capacity from the $500 \mathrm{Wh} / \mathrm{K}$ of the basic test cell (the same for both cabins) to $1400 \mathrm{Wh} / \mathrm{K}$. The south facing triple glazed window area is $2.9 \mathrm{~m}^{2} .13$ temperature sensors are incorporated in the cell to measure air and critical surface temperatures.

The solar trap cell includes $3.8 \mathrm{~m}^{2}$ of double glazing at the outer window opening (housing the absorber blind) and a similar $2.9 \mathrm{~m}^{2}$ of aperture to the cabin interior. The rock storage contains $1.7 \mathrm{~m}^{3}$ of rock or approximately $2720 \mathrm{~kg}$, which is thermally isolated by $60 \mathrm{~mm}$ of insulation from the cabin interior. The fan connecting the window to the storage has a $110 \mathrm{~W}$ motor. The cabin performance is measured with 45 sensors located on the surface of each wall, at different heights within the cabin, within the solar trap air space, at its inlets and outlets, and at different levels in the rock bed storage.

Meteorological data are provided by an on-site weather station.

The solar trap system operates as follows:

When the temperature in the solar trap window reaches $30-45^{\circ} \mathrm{C}$, (varies by the time of year), a ventilator is activated automatically. Air is then circulated to the rock bed storage, as shown in the figure $16 \mathrm{a}$. The heat is retrieved from storage when needed by circulating room air 
through the rock bed. Alternatively, the room can be heated by circulating air from the rock bed through a heat exchange wall (hypocaustum) in a closed loop. At night, the blind is lowered. The blind in combination with the triple glazing performs as a very well insulated window.

To reduce summer overheating of the space a thermosiphon cooling mode is possible, as shown in figure $16 \mathrm{~b}$. Cool air from the north side of the cell is drawn through the storage, across the sun heated blinds between the two glazings and then convected to the outdoors. An airflow rate of $50 \mathrm{~m}^{3} / \mathrm{h}$ has been measured. Peak temperatures in the cell are thus lowered as much as $10^{\circ} \mathrm{C}$.

Virtually no solar radiation enters the room with the blinds shut. The surface temperature of the blinds reaches up to $70^{\circ} \mathrm{C}$ resulting in an inner glazing temperature of more than $40^{\circ} \mathrm{C}$, however. Consequently the test cell is still subject to indirect heating and subsequent overheating. A heat reflective film on the inner glazing has been tested as a solution to this problem. During solar collection periods the film reduced test cell temperatures $2-3^{\circ} \mathrm{C}$. During nights the reflective film would also provide additional insulation. A more plausible solution to overheating is probably exterior shading, such as by an overhang or awning.

\section{Status}

Data collection is now completed for each of the three modes of operation: hybrid heating, passive heating, and passive cooling. The data have been analyzed and design recommendations published in a final report. A prototype house has been constructed and is currently being instrumented. 


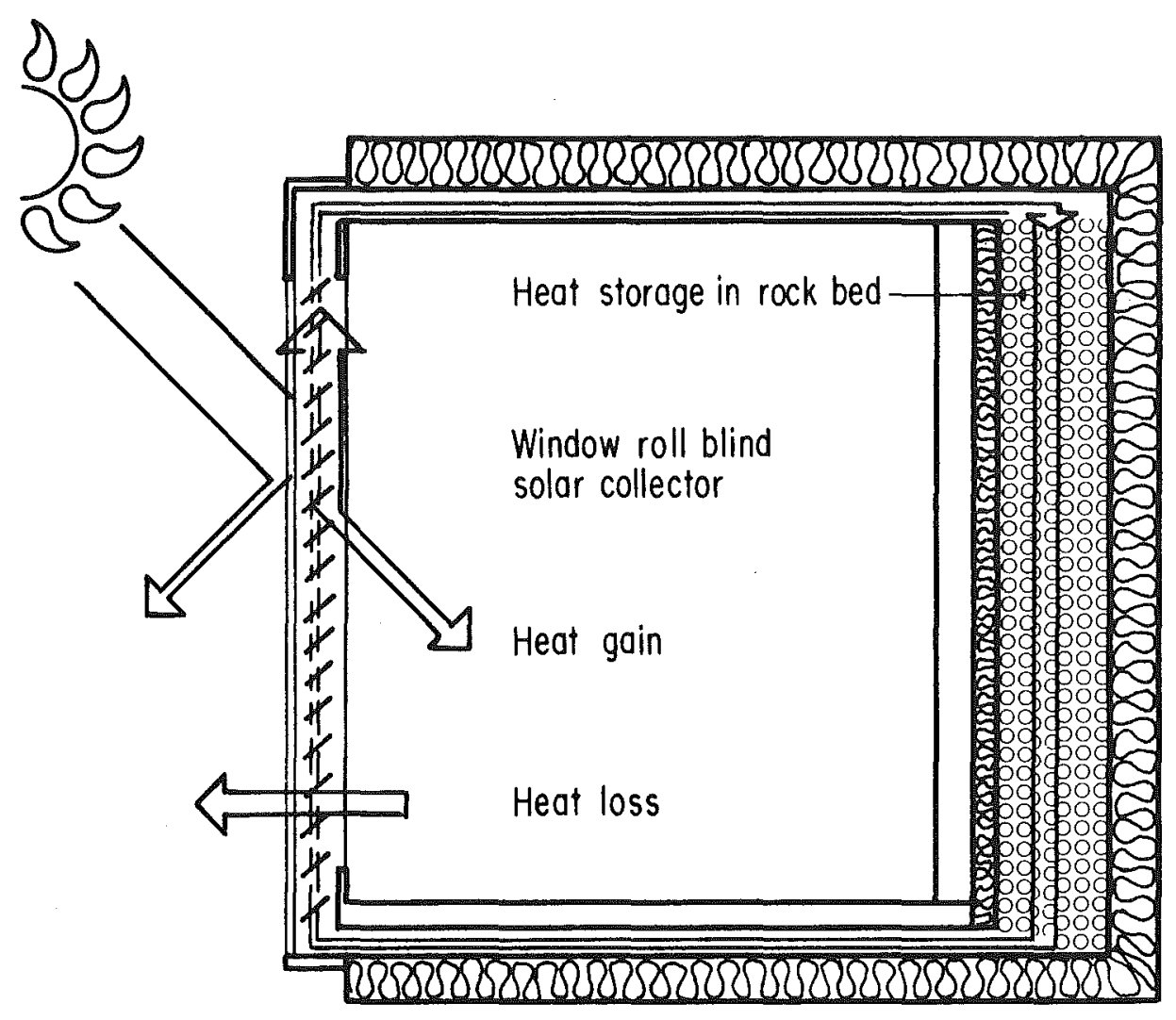

Fig. 16a Active collection mode

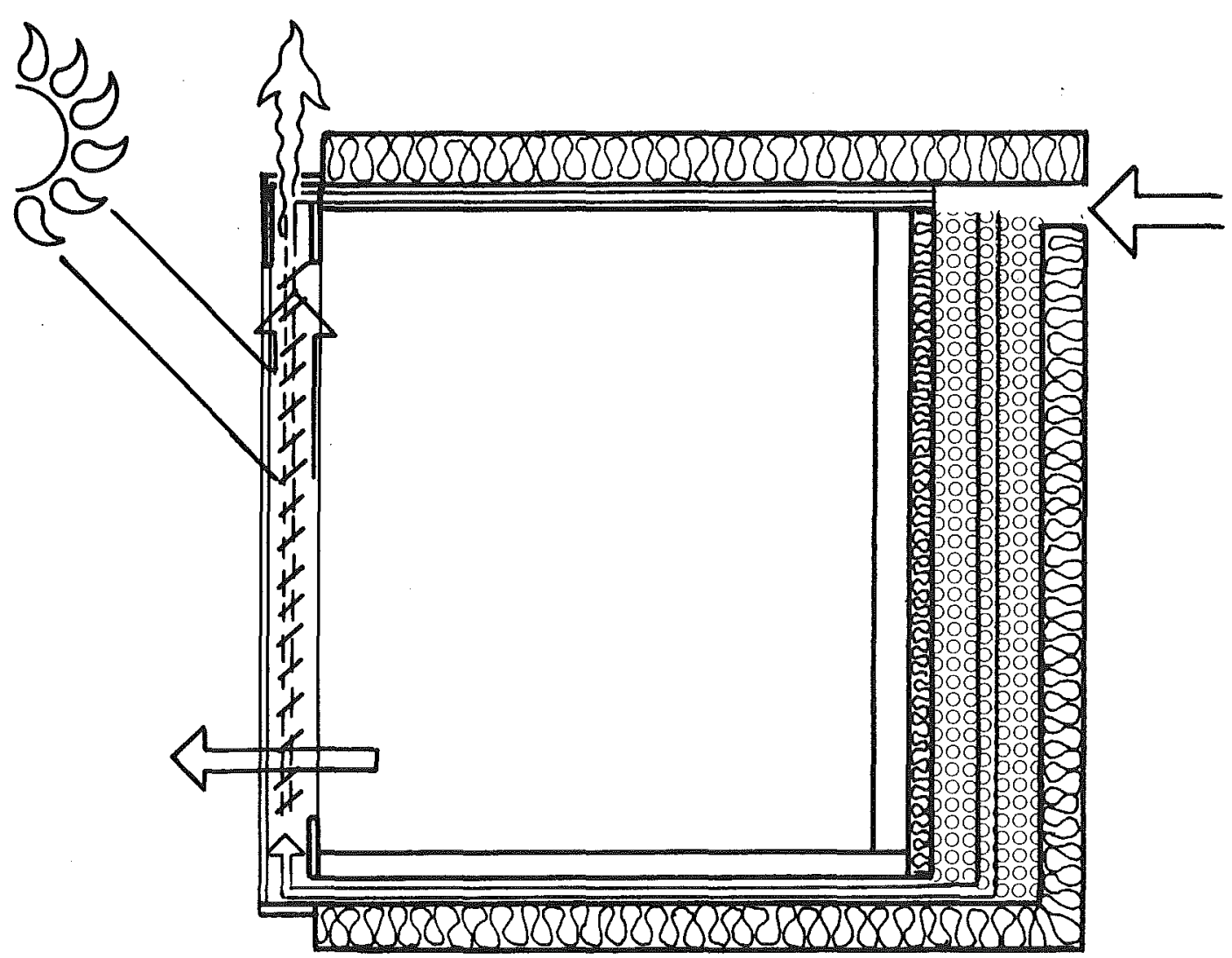

Fig. $16 \mathrm{~b}$ Summer Thermosyphoning Mode 


\section{Example Results}

Solar Trap and direct gain (test cell) temperatures are compared for two characteristic periods in the figures 17 and 18. Building load coefficients exclusive of the window area are identical for both cells. The resulting solar contribution in the Solar Trap cell reached $85 \%$ in October/November and $35 \%$ in December respectively. Conditions of comfort as indicated by the inside temperature, were significantly better in the Solar Trap cell than in the mass cell.

\section{Comments}

The results obtained to date with the "Solar Trap" window-collector and the rockbed storage show that a well designed system may supply more than 50 percent of the heat needed during winter months. For short-time thermal storage the rockbed performs adequately.

While the performance of the solar trap appears impressive relative to direct gain solar heating, it must be noted that the direct gain test cell did not include any night insulation and hence experienced substantial night radiation losses and subsequently large temperature excursions. While a practical night insulation is lacking in the Swiss market, the potential of a direct gain system should not be underestimated based on the data this project provides.

Future research would be useful considering the coupling of the solar trap window with a latent heat storage system which would decrease volume required by the present rock storage system. The fan motor size could also thereby be decreased.

\section{Publications}

"Forschungsprojekt Solar Trap: Passive und aktive Sonnenenergienutzung bei Gebäuden", Thomas V. Kurer, Reto Lang, Basler \& Hofmann, Forchstrasse. 395, 8029 Zürich, Switzerland, April 1981 

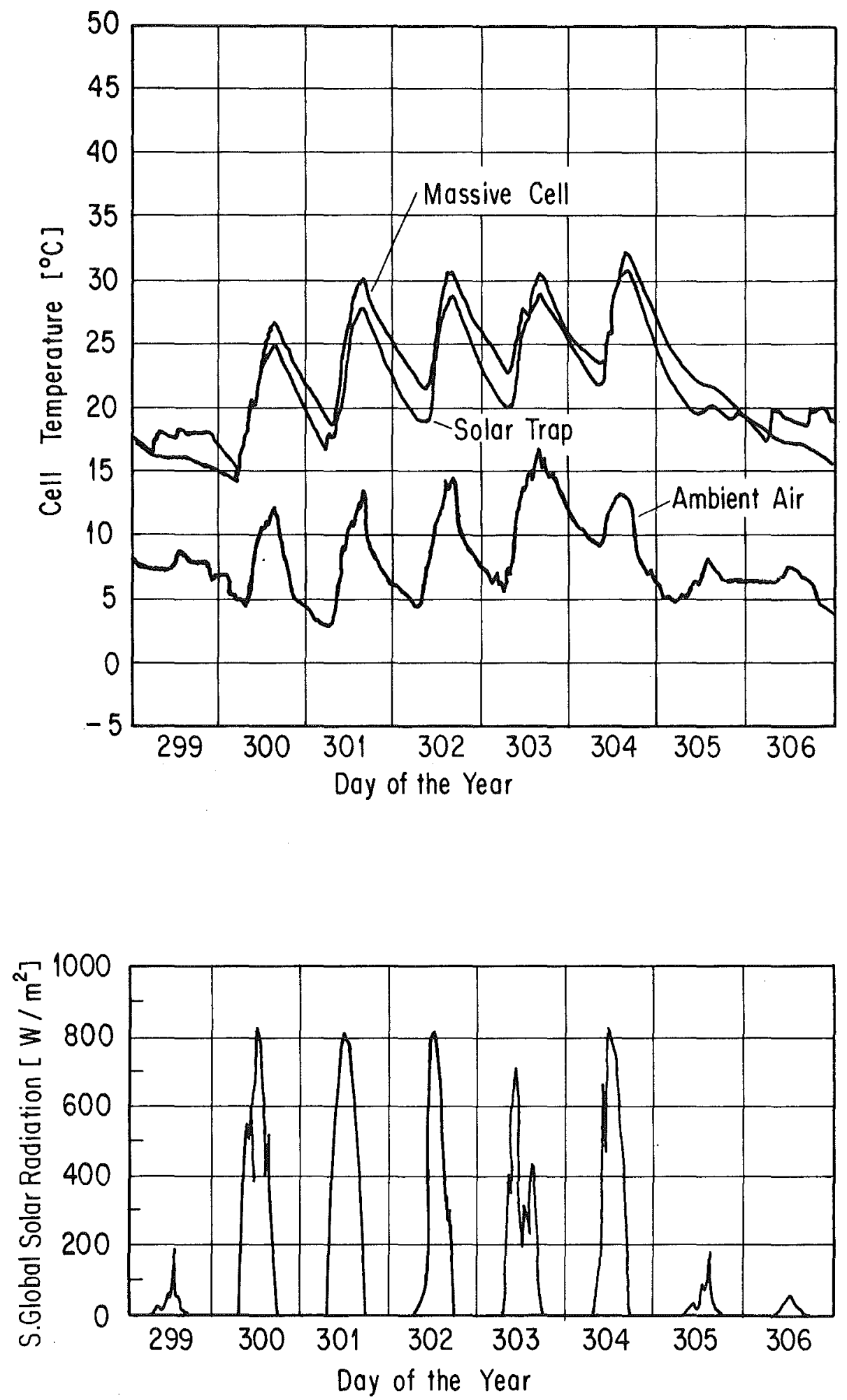

Fig. 17 Test Cell Performance in October/ November 

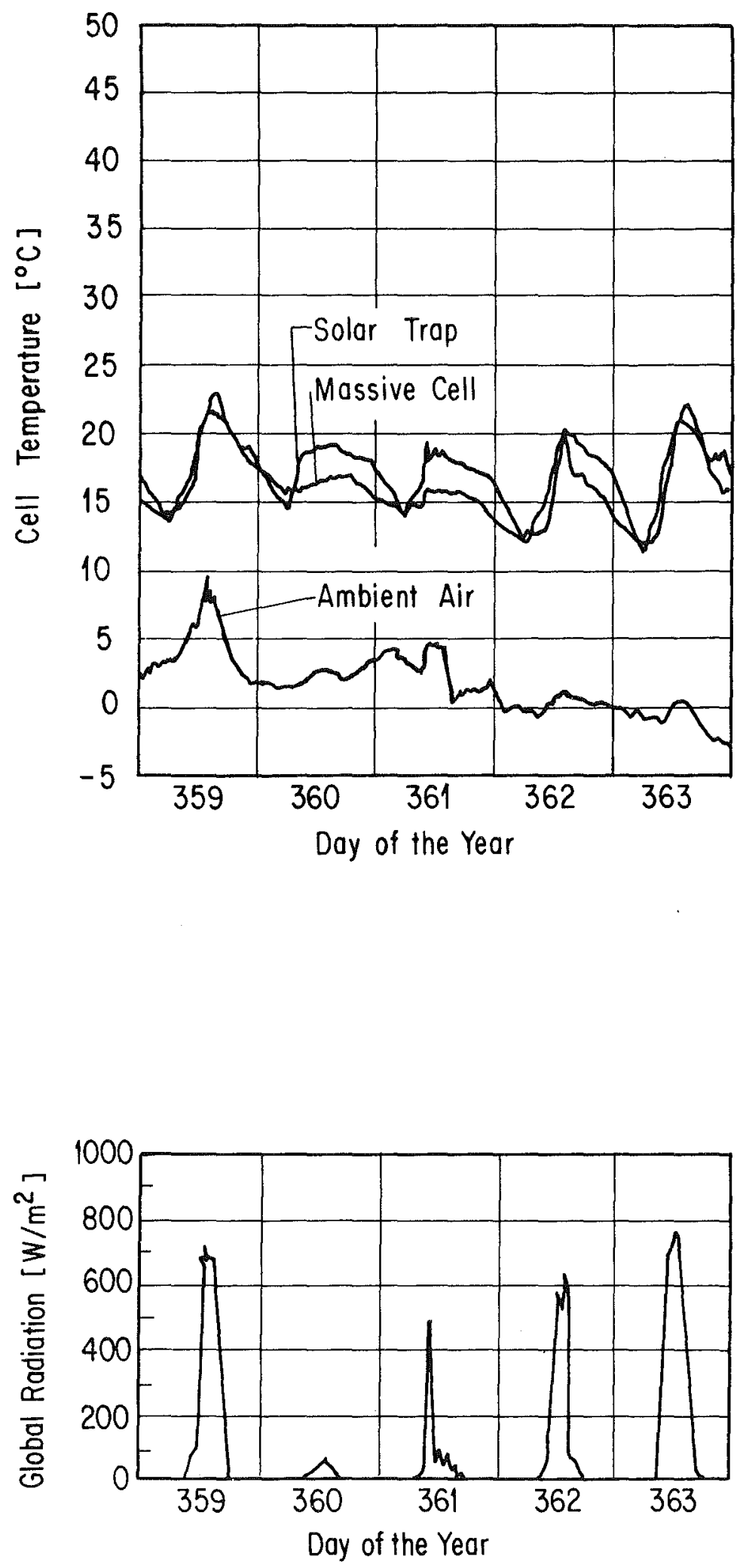

Fig.18 Test Cell Performance in December 


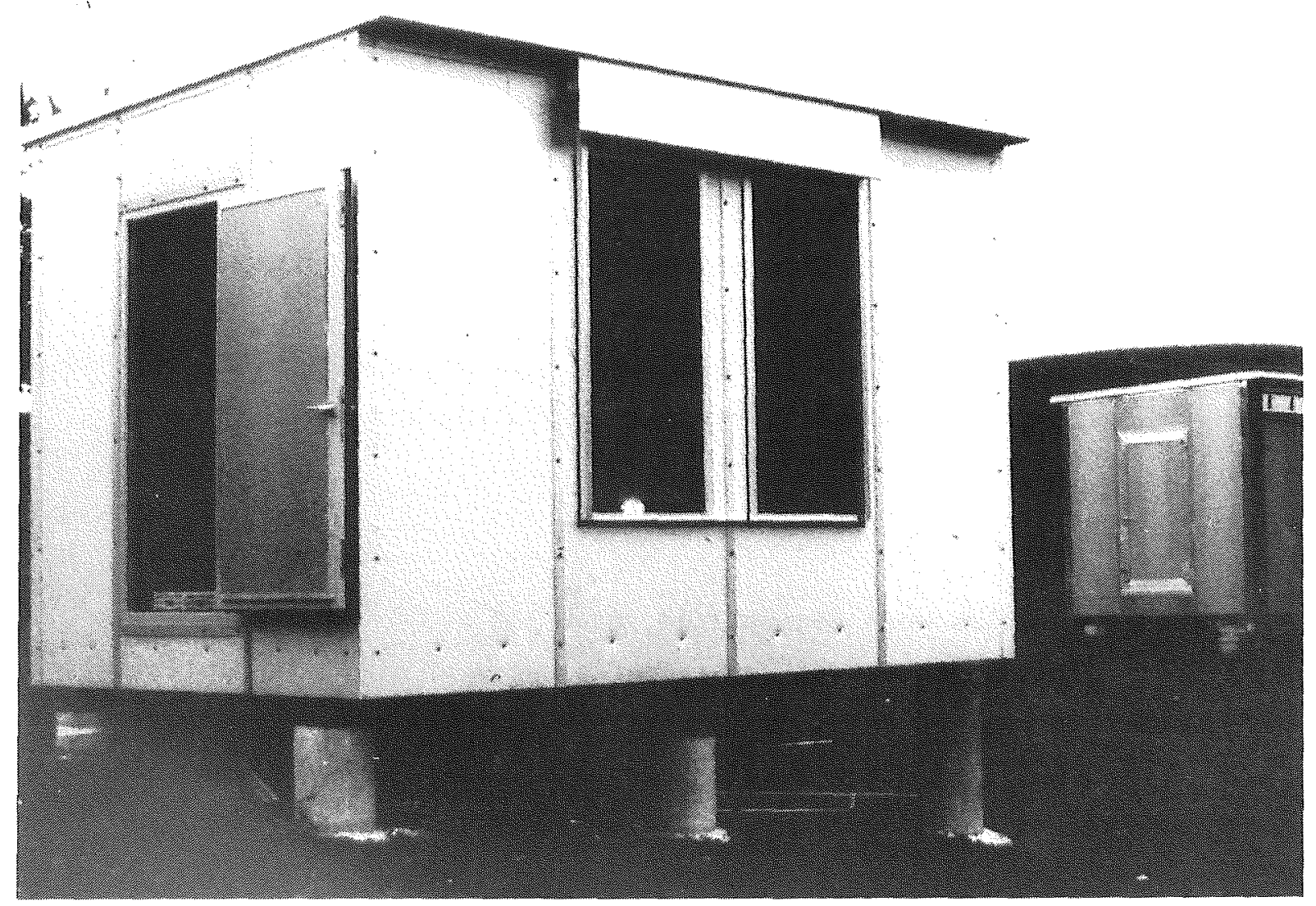

\subsection{MAUGWIL TEST CABINS}

\section{BACKGROUND}

Two test cabins have been constructed to measure the importance of the radiative properties of a building facade relative to the building's heating demand. The project was begun in 1979 and is scheduled for completion in 1982. Prof. K. Kneubuihl of the Solid State Physics Laboratory at the ETH-Z and R. Sagelsdorff and T. Frank of EMPA are the project leaders. 


\section{Objectives}

- Measure how the radiation properties of building facade materials, in interaction with solar radiation and sky counterradiation properties, affect the heat balance of the building envelope.

- Measure the energy consequences of a south-facing window regarding the above radiation properties.

- Provide measured data to validate a computer model on the role of radiation mechanisms in determining heating and cooling loads.

\section{Approach}

Two test cabins were constructed, each $3.0 \times 3.0 \times 4.5 \mathrm{~m}(\mathrm{w} \times \mathrm{h} \times 1)$. Construction details and specifications are shown on the following page. One cabin has a conventional clear annodized aluminum exterior $\left(E_{0}=0.92\right)$, the other a selective reflective chromated aluminum exterior $\left(E_{0}=0.07\right)$.Figure 19 illustrates these properties.
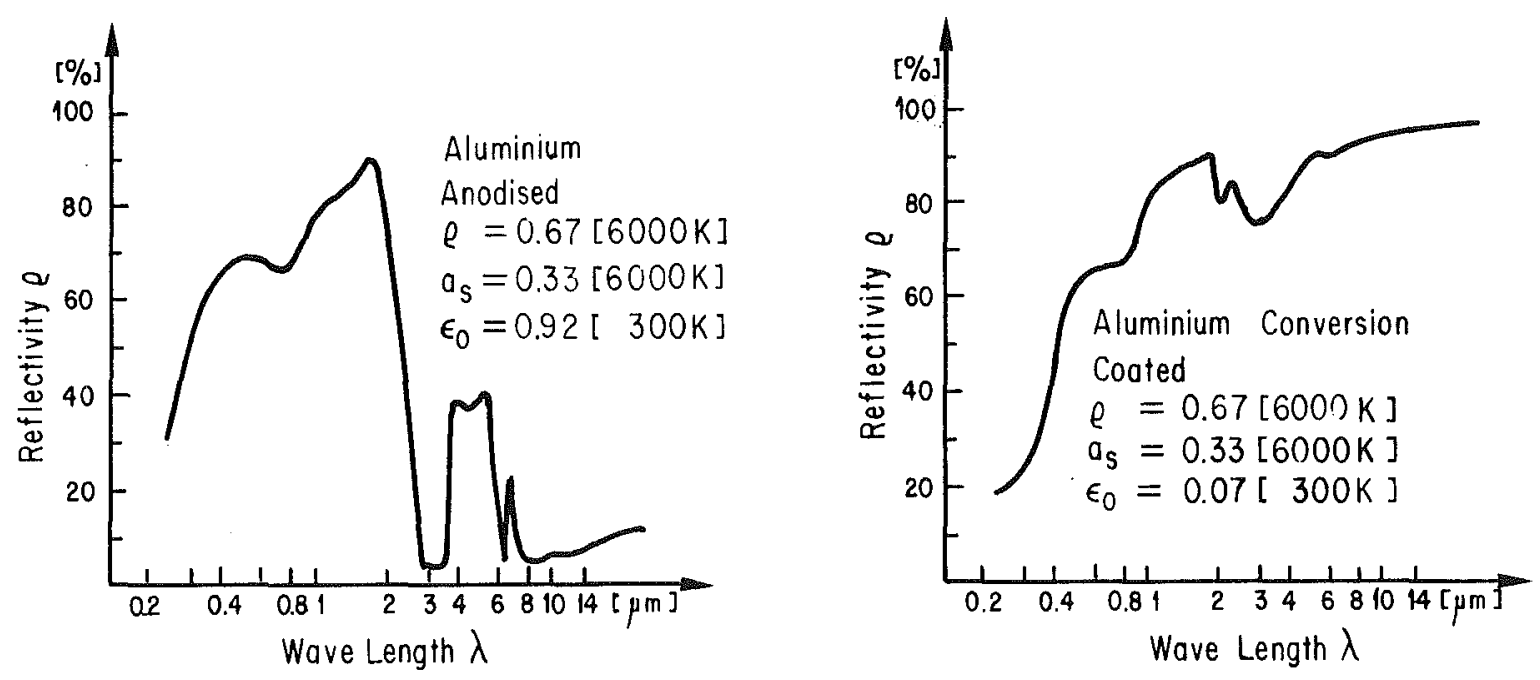

Fig. 19 Radiation Properties of the two Types of Aluminium Panels 


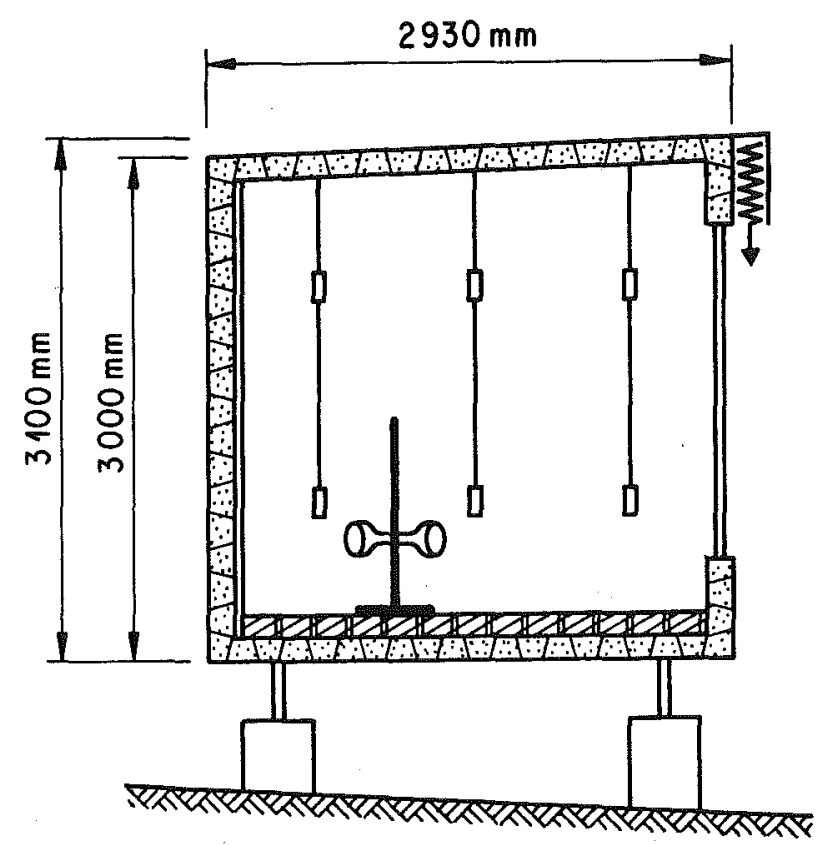

Fig. 200 Cabin No. 1

(Anodized Al. Skin)

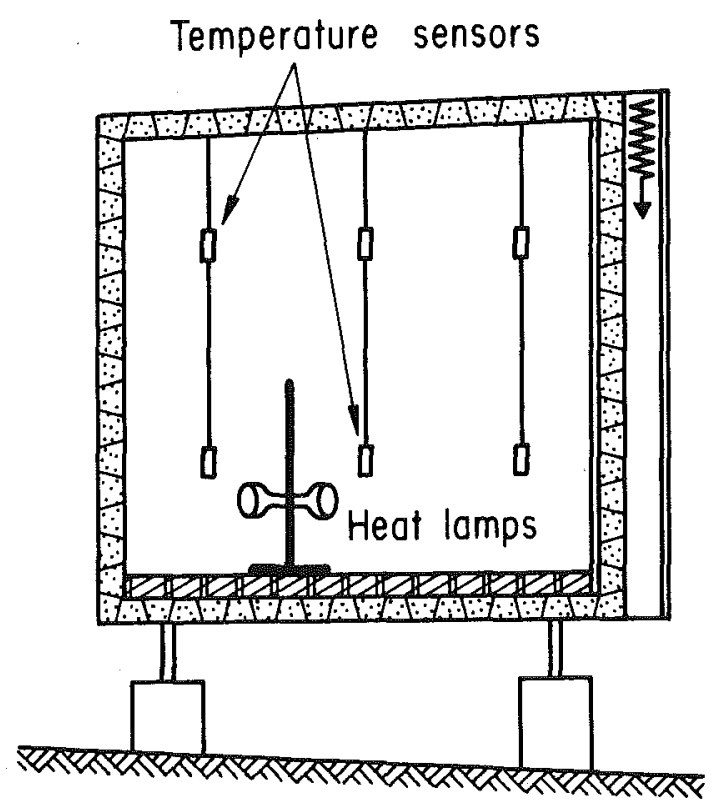

Fig. $20 \mathrm{~b}$ Cabin No. 2

(Conversion coated skin)
Cabin No. 1.

-Double glazed windows $1800 \times 1900 \mathrm{~mm}$ with exterior roll blind.

-Clear anodized aluminum exterior.

$-70 \mathrm{~mm}$ polystyrene in walls and roof. $-60 \mathrm{~mm}$ polystyrene in floor.

$-60 \mathrm{~mm}$ gypsum panels interior of black wall (north wall interior) $-1000 \mathrm{~kg}$ brick floor -Four 250W IR lamps as heat source.

-10 air temperature probes (each corner and center) placed low and high.

Cabin No. 2

(Differences from No.1)

-No window.

two sheets of acrylic over south facade.

-Low emissivity aluminum facades and roof.

$-60 \mathrm{~mm}$ gypsum panel south wall interior.

-Roll blind between acrylic sheets and opaque wall.

-Temperatures measured at surface of glazing, air space, surface of roll blind, surface of aluminum. 
During the first winter of the project measurements were taken of all inside and outside cabin surface temperatures, inside air temperatures at ten locations per cabin, and electric heating consumption of each cabin. A weather station at the site recorded ambient air temperature and humidity; wind speed and direction; global solar radiation on horizontal, N., S., E., and W. vertical surfaces; diffuse radiation on a horizontal surface, and infrared radiation on a horizontal and a south vertical surface. Data from the two test cabins and the weather station were recorded with a 140 channel data acquisition system controlled by a programmable desk computer located in the adjacent Maugwil house.

During the second winter, a double glazed window $1800 \times 1900 \mathrm{~mm}$ was incorporated in the south facade of the annodized aluminum cabin. An automated conventional aluminum exterior roll blind was installed outside the window. The blind, under the control of the desk computer, was lowered when the solar intensity fell below $5 \mathrm{w} / \mathrm{m}^{2}$.

The conversion coated aluminum cabin was outfitted with an acrylic double glazing covering the entire south facade. An automated blind was installed in the air space between the aluminum facade and the acrylic sheets. The blind was operated by the same control program as used by the other cabin. Both cabins contained internal mass to even out the temperature extremes. Both cabins were heated by four 250 watt infrared lamps oriented $45^{\circ}$ off axis in plan to provide more uniform interior surface irradiation. The lamps were thermostatically controlled to heat the cabins to $20^{\circ} \mathrm{C}$.

\section{Status}

The second winter of data collection has now been completed. A computer program has been written which assembles raw data from the cabins and generates daily summaries. Sufficient data are now available to permit the validation of the mathematical simulation model and it is currently 
under revision and further development. Upon completion of the data collection a final report assessing the effectiveness of the various strategies will be completed in late 1982 . The cabins have recently been disassembled, transported to EMPA, and reassembled for a third winter of measurement.

\section{Example Results}

The exterior surface temperature profiles for the anodized aluminum facade and the conversion coated aluminum facade relative to the ambient temperature are shown in figure 21. The conversion coated facade temperature is always higher than both the ambient and the anodized facade temperatures. During a sunny day this difference is most pronounced. During clear nights the anodized face temperature falls below the ambient temperature due the substantial night sky radiation losses.

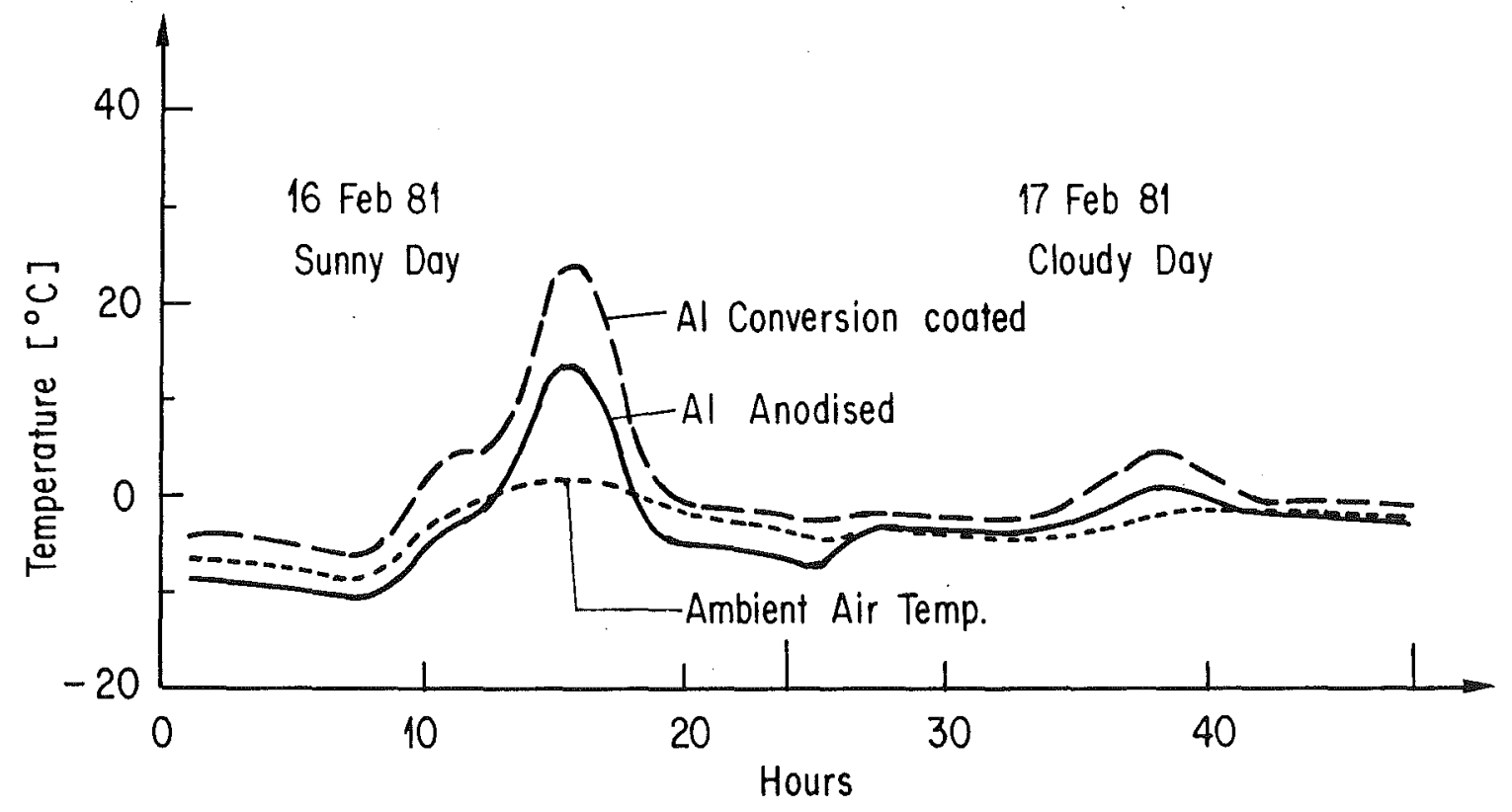

Fig. 21 West Wall Exterior Surface Temp. 
Figure 22 illustrates the surface temperatures of the south facades of the two cabins relative to the ambient temperature but here the south facade of the conversion coated facade has an acrylic cover glazing. The glazing and trapped air space substantially amplify the difference in surface temperatures between the cabins. The conversion coated surface behind the glazing reached $70^{\circ} \mathrm{C}$ compared to the unprotected anodized surface reaching $18^{\circ} \mathrm{C}$ on a day where the ambient temperature peaked at $2^{\circ} \mathrm{C}$.

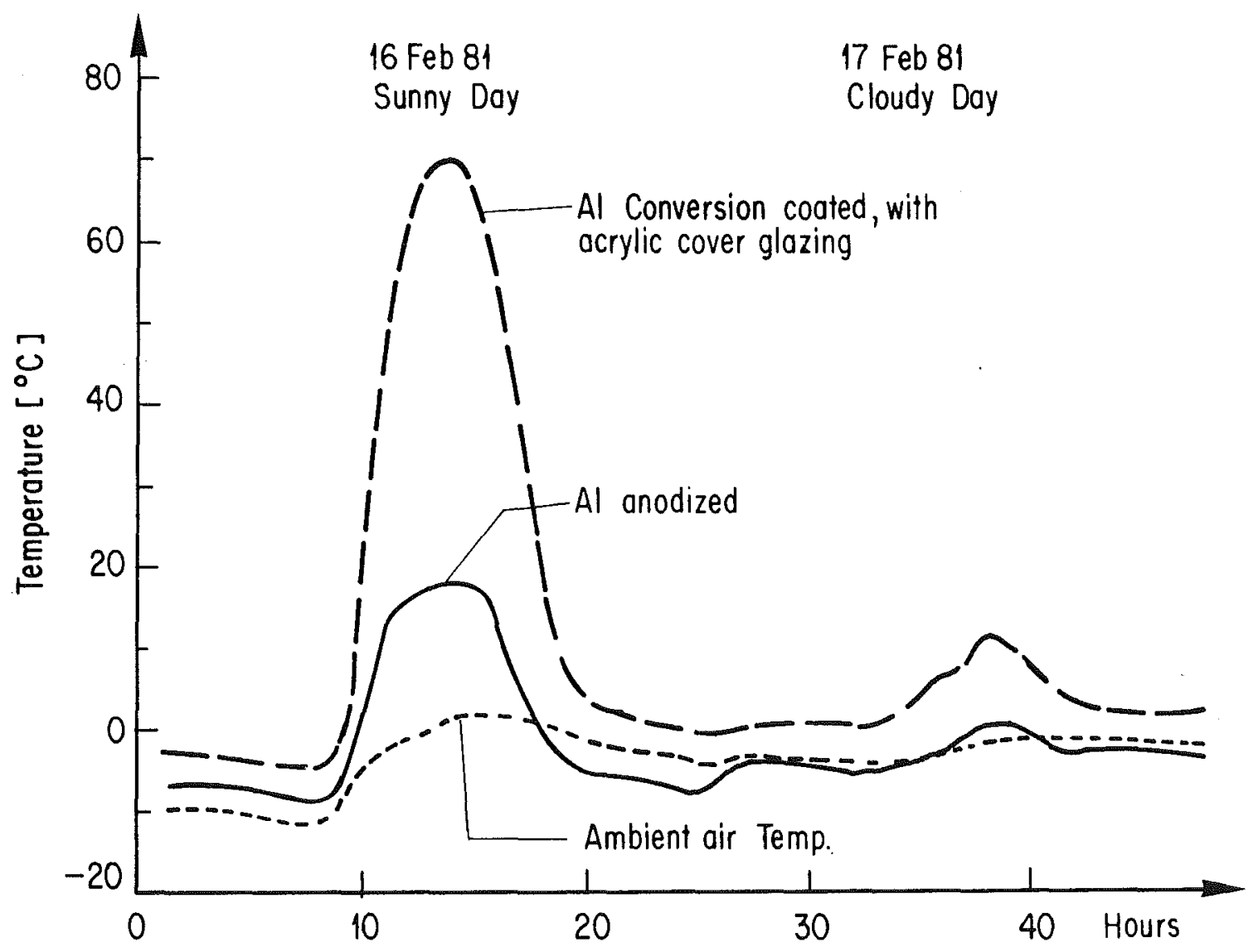

Fig. 22 South Wall Exterior Surface Temp. 
Figure 23 illustrates the end result of the surface temperature differences between the two cabins, namely, the difference in power consumption required to maintain $20^{\circ} \mathrm{C}$. During the nights the conversion coated cabin required less power due to the reduction of IR radiation losses. During the day the anodized cabin with the window required less power for heating due to the solar gain of the window.

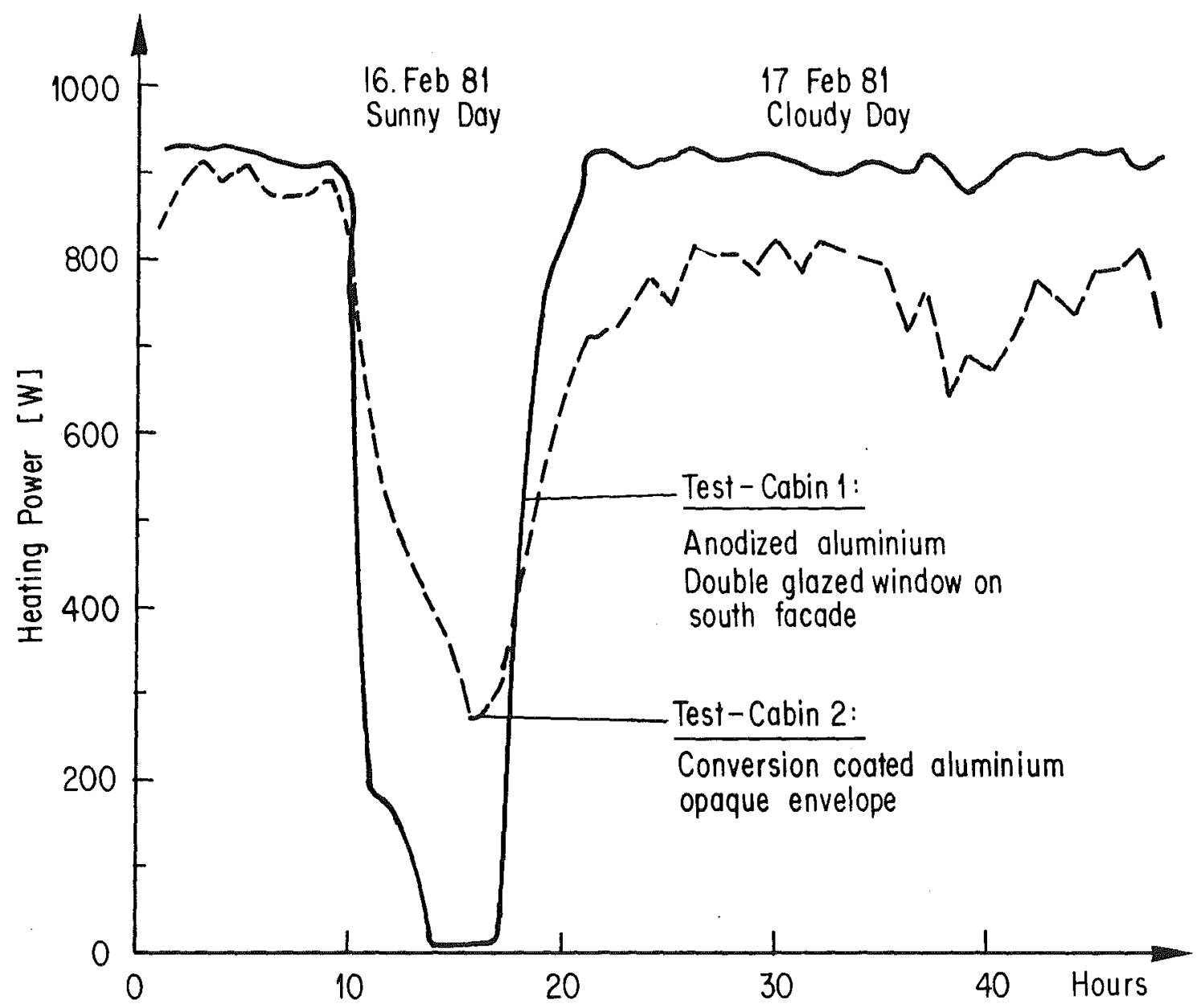

Fig. 23 Heating Power Consumption 


\section{Comments}

The primary objective of this experiment is to study the consequences of a selective reflective surfaced building shell in comparison to a conventional aluminum panel type building shell. To provide an extreme contrast, the roof as well as the four sides of the cabins are clad with the same aluminium or coated aluminum. By treating the roof similarly, the maximum sky exposure of this surface provides pronounced differentiation between the two types of surfaces. In interpreting the results, however, care must be exercised in making projections for real buildings because of the unlikelihood of their having aluminum clad roofs. The cabin outfitted with an acrylic sheet over the south-facing selective reflective aluminium provides a valuable measure of the effect wind has on stripping away heat from the surface of the cabin, in contrast to heat lost by reradiation from the aluminum to the ambient environment.

The measurements indicate that when a building envelope is specially treated to reduce IR radiation heat losses a considerable reduction in auxiliary heating is possible. Energy savings from reduced heating requirements can be offset by increased cooling requirements in the summer, however.

In future years it would be useful to investigate reconfigurations of the test cabins. For example, the conversion coated cabin could be configured with a window to provide direct solar gain, more realistically representing an actual application. The other test cabin could be outfitted with an attached sunspace with insulated opaque ends, double glazing, night insulation, and a water wall separating the test cabin from the sunspace. Such a configuration would provide valuable measured data on the number of hours the sunspace temperature and humidity were within the comfort band, and the annual heating contribution the sunspace was able to make to the test cabin. Also, auxiliary heating requirements to maintain the sunspace above the minimum tolerance temperature of specified plants could be measured. 
Another valuable experiment would be to outfit the cabin having the selective reflective coating with a slatted metal sunscreen. The blades of the sunscreen would be fixed at an angle to block summer sun but admit winter sun. Such a configuration would reduce the summer overheat problem which the selctive reflective surface exacerbates. The screen would further act as a partial wind screen in winter, helping preserve the boundary layer of air at the facade.

For both the sunspace configuration and the sunscreen selective reflective configuration, it is worth considering painting the roofs gray, approximating the color of aged built-up roofs, or installing a curb and placing gravel on the roof. Either of these two conditions would more realistically represent actual roof conditions.

\section{Publications}

Kälin, R. und Kneubühl, F., "Die Verminderung des Wärmeverbrauchs von Gebäuden durch Infrarotverspiegelung von Fenstern, Fassaden und Dächern", Gesundheitsingenieur Nr. 98, 1977

Kneubühl, F., Frank, T., et.al. "Energy savings by Reduction of the Thermal Radiation from Building Envelopes", International Conference on Building Energy Management, Porto, Portugal, May 1980.

Sagelsdorff, R., Züricher, Ch., Frank, T. "Einfluss der Strahlungsvorgänge an der Gebäudehülle auf den Energieverbrauch" Proceedings of the 11. Kongress der Internationalen Vereinigung für Brücken- und Hochbau, Wien, Aug. 1980 . 


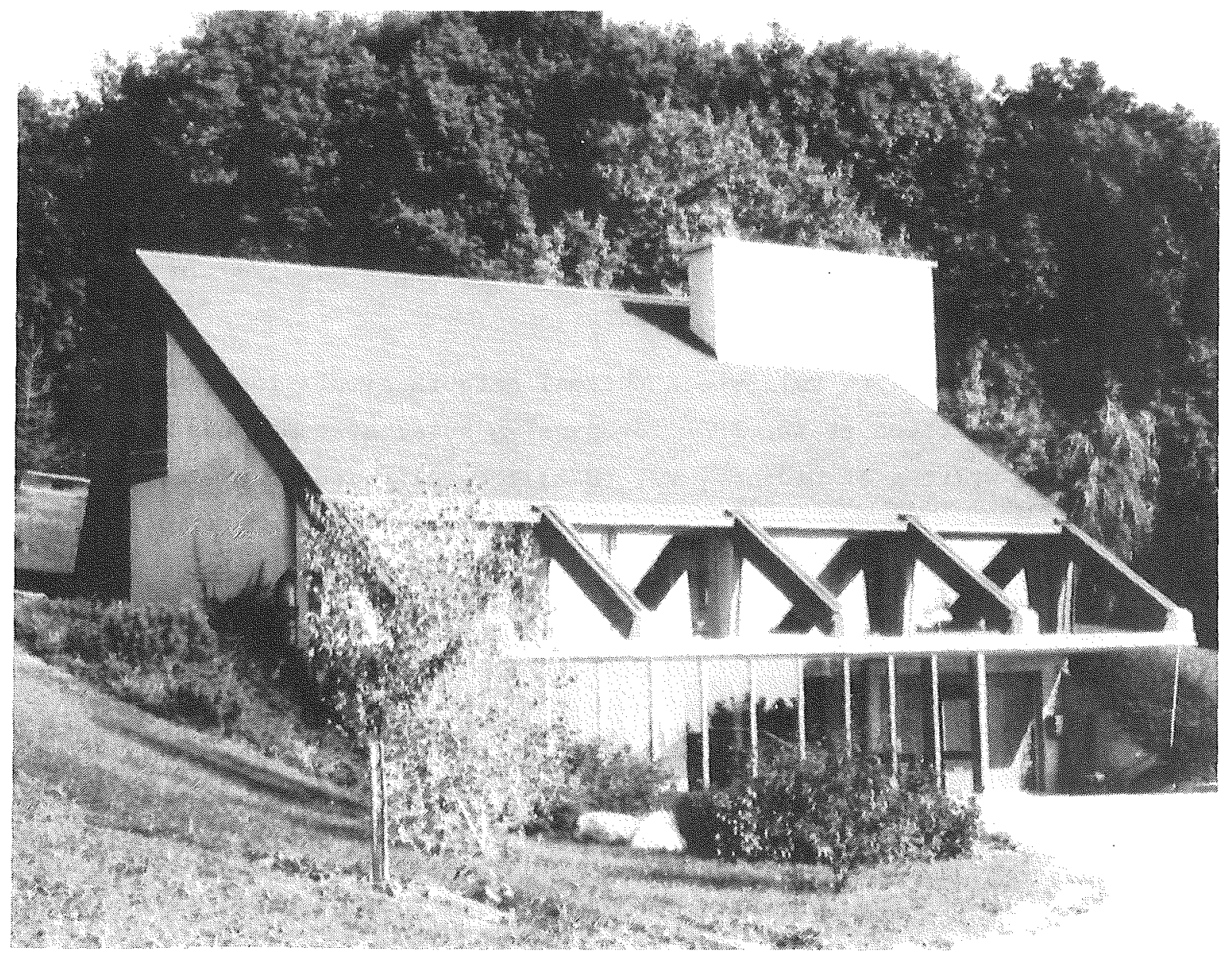

\subsection{THREE PASSIVE SOLAR HOUSES}

\section{BACKGROUND}

Three passive and two active solar houses in Switzerland are being monitored and computer modeled. This work is a part of International Energy Agency Task I. G.-R. Perrin of the Solar Energy Group of the EPFL $*$, is the project leader. The data are intended as a basis for commenting on the effectiveness of various passive solar strategies under Swiss conditions of climate and architectural style.

* Laboratoire de Pysique Théorique, Groupe de Recherche en Energie Solaire (Professeur A. Faist)

Institut de Thermique Appliquée (Professeur P. Suter) 


\section{Objectives}

- Assess the performance of solar houses (active \& passive) in their local climate.

- Provide a means to validate a thermal network simulation program, "PASSIM" written at the EPFL for passive solar systems, and the TRNSYS program written at Madison, WI, (USA) for active solar systems.

\section{Approach / Method}

Five solar houses were selected for monitoring. These were:

1.) a house in Begnins (pictured on the title page)

2.) a house in Les Geneveys/Coffrane

3.) a house in Renens

4.) a house in Payerne

5.) a house in Savuit

Each house will now be discussed.

1) The "Begnins" house, illustrated in Fugure 24, is a direct gain house with a recently added attached greenhouse. The house was constructed in 1977. It has been monitored from autumn 1978 through summer 1980. The walls have an insulation value of $0.42 \mathrm{~W} / \mathrm{m}^{2} \mathrm{~K}$ and the roof has value of $0.2 \mathrm{~W} / \mathrm{m}^{2} \mathrm{~K}$. A 64 channel analog 8 pulse counter with integrator, scanner, and magnetic cartridge recorder has been used to collect measured data. 


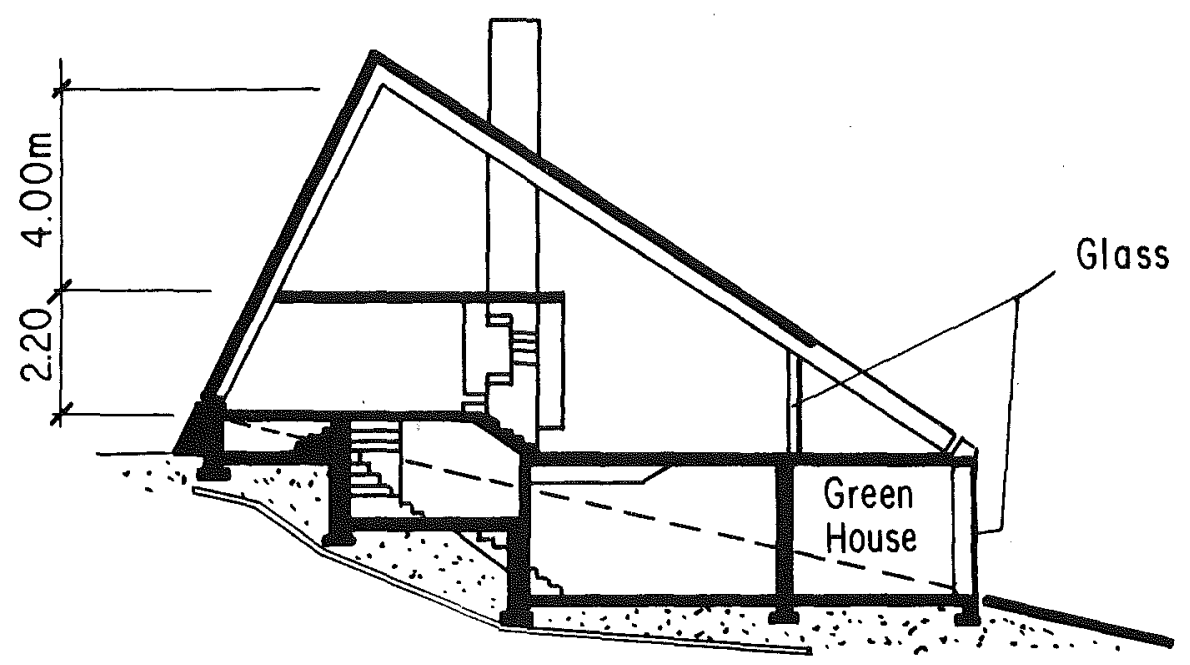

Transverse Section

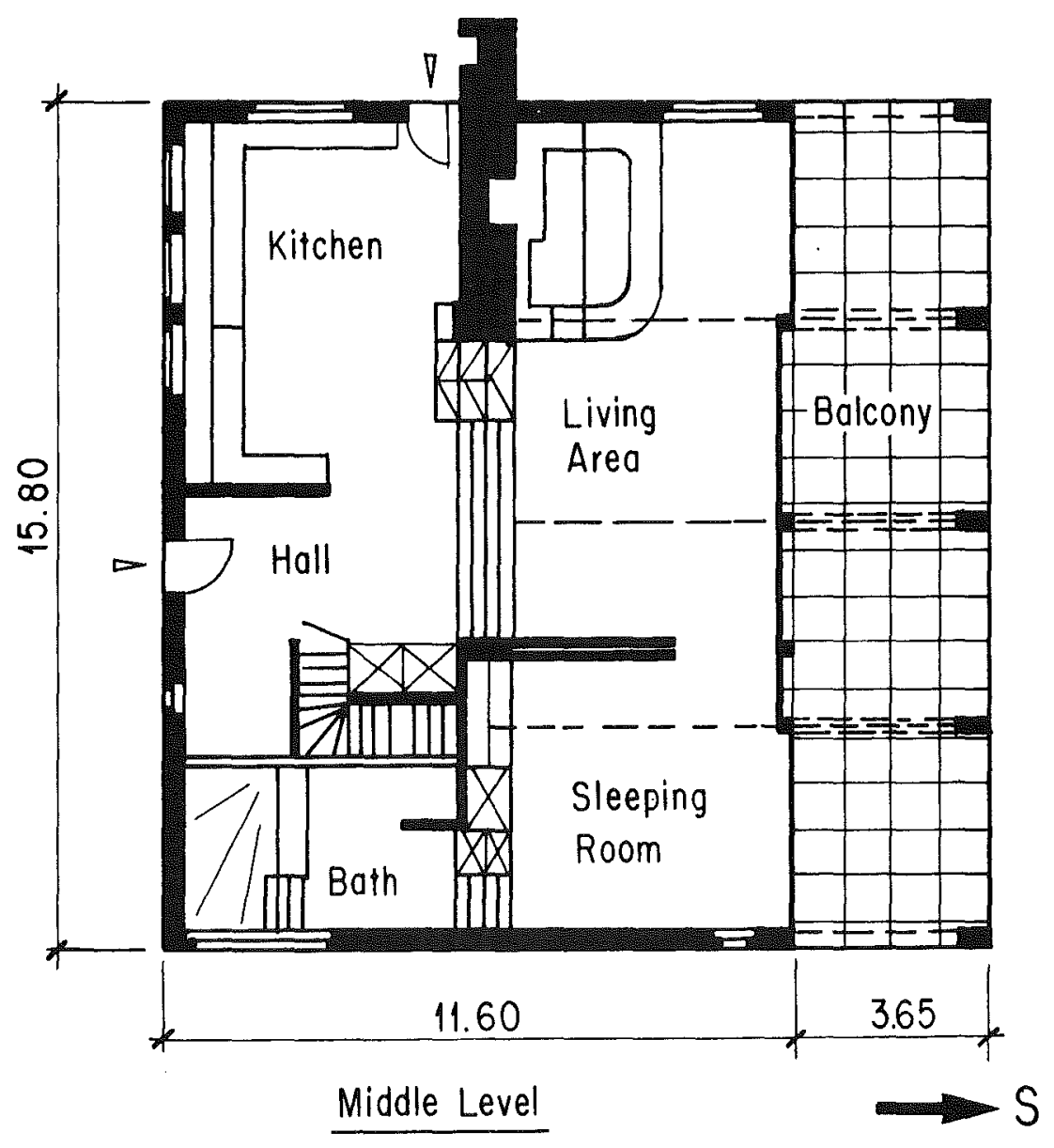

Fig. 24 Begnins House Plan and Section 
2) The "Geneveys" house is a passive and active solar house, built in 1979. Measurement started in the spring of 1979 and will continue through the summer of 1981 . The building is well insulated (walls $0.32 \mathrm{~W} / \mathrm{m}^{2} \mathrm{~K}$, roof $0.20 \mathrm{~W} / \mathrm{m}^{2} \mathrm{~K}$ ). The floor plan incorporates a buffer zone on the north side. A greenhouse is the primary passive solar element. It is double glazed and has a reflective aluminized Polyester curtain used during winter nights as infrared reflective insulation and during summer days as a sun shade. The active system consists of $24 \mathrm{~m}^{2}$ of air collectors with $4 \mathrm{~m}^{3}$ of rock thermal storage plus a rockbed under the ground floor with a pipe system for channeling the air evenly through the rockbed. This system has not yet been completed.

3) The "Renens" house completed in 1980, has a Trombe wall (14 $\left.\mathrm{m}^{2}\right)$ and an integrated greenhouse. The monitoring period will end early in 1982. A Hewlett Packard data acquisition system is used (HP $9835 \mathrm{~A}+$ scanner + digital voltmeter + pulse counter + HP cassette recorder). The house is well insulated (walls $0.3 \mathrm{~W} / \mathrm{m}^{2} \mathrm{~K}$, roof $0.2 \mathrm{~W} / \mathrm{m}^{2} \mathrm{~K}$ ) and is tight $(0.3-0.5$ air changes per hour).

4) The "Payerne" house is a conventional Swiss single dwelling with an integrated active liquid solar system $20 \mathrm{~m}^{2}, 43^{\circ} \mathrm{Tilt}$, (south-west orientation). The system has been measured since January 1980 . The house is well insulated (walls $0.4 \mathrm{~W} / \mathrm{m}^{2} \mathrm{~K}$ ). A 64 channel analog datalogger, and 12 pulse counter with integrator are used with a magnetic cartridge recorder.

5) The "Savuit" house is a single dwelling with an active solar system $\left(22 \mathrm{~m}^{2}\right)$ isolated from the main building. This system is rather complicated but allows the researcher to examine the effect of variations of storage mass to collector area. The system is instrumented with a 64 channel analog, 8 pulse counter data-logger. 
Measured parameters at each of the five buildings include local meteorological conditions, solar system performance, building inside air temperatures, infiltration rates, and back-up heating energy consumption. The method of analysis and documentation is the same for the three passive houses (IEA Reporting Format). The "Begnins" house project will now be described in more detail.

The "Begnins" house is a direct gain design. The southern facade is entirely windows ( $28 \mathrm{~m}^{2}$ of glass). Local overheating is minimized by the tiled concrete floor, masonry walls and masonry mass incorporating a fireplace (total $43 \mathrm{~m}^{3}$ of concrete). The largely open, two-story floor plan provides free air circulation, minimizing temperature stratification (confirmed by measurement). During the night, roll blinds are lowered on the south windows and moveable insulating panels are placed in the east and west-facing windows.

A wood stove is the principle auxiliary heat source.

\section{Status}

Data collection from the "Begnins" house is completed.

Data collection from the "Geneveys/Coffrane" house is completed. New data will probably be collected when the air system becomes operational. Data collection in Renens, Payerne, and Savuit is still underway and will be completed at the end of 1981 .

Available data from the three passive buildings are currently being used to validate a thermal network program, PASSIM, and one of the two active systems is being used to validate the TRNSYS program. 


\section{Example results}

After two and a half years of experience, and one year of measurements from the Begnins house, the project researchers were disappointed that the solar fraction was smaller than expected ( $30-47$ percent). In fact, initially they had overestimated the losses of the building and under estimated the internal heat generated by the lighting, electric equipment and people. These influences in combination substantially reduce the heating period, thereby reducing the period when solar collection can be credited. The heat load of the building is small because the owners prefer room temperatures of $16-19^{\circ}$ rather than the more common $20-22^{\circ} \mathrm{C}$, and because in a relatively well-insulated and airtight building the internally generated heat meets a substantial proportion ( $30-60$ percent) of the load.

These considerations do not mean that the building is a poor solar design. They prove, on the contrary, that it is possible even given Swiss climate conditions, to build a low energy consuming house taking advantage of solar direct gain. Figure 25 illustrates the performance of the Begnins house. The minimal extent of the temperature stratification which occurs even on clear days is shown. Table 3 details the low extent of energy use by the Begnins house. 


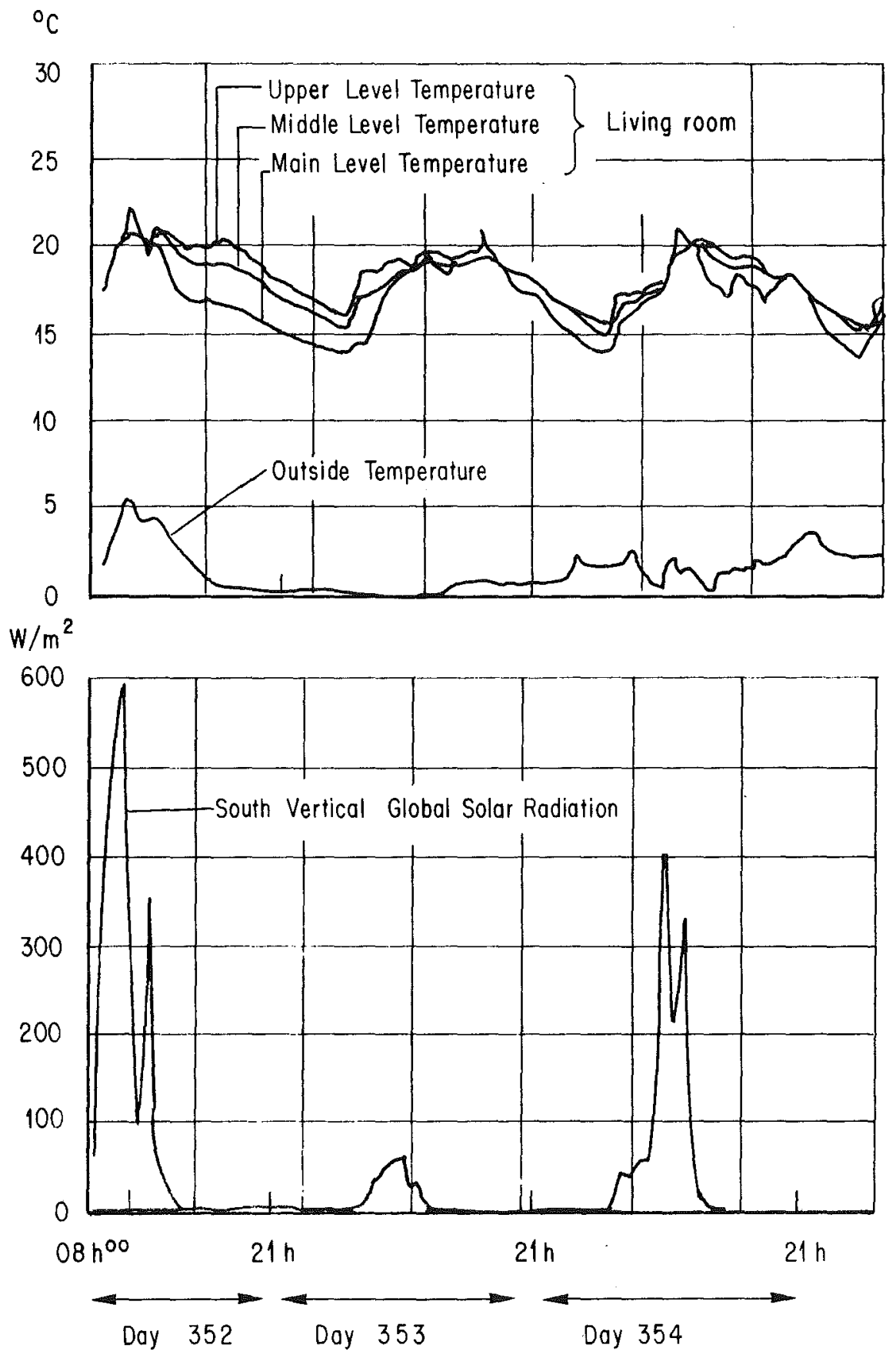

Fig. 25 Temperature Stratification of the Begnins House 
Table 3 Begnins House Energy Consumption 1979-80

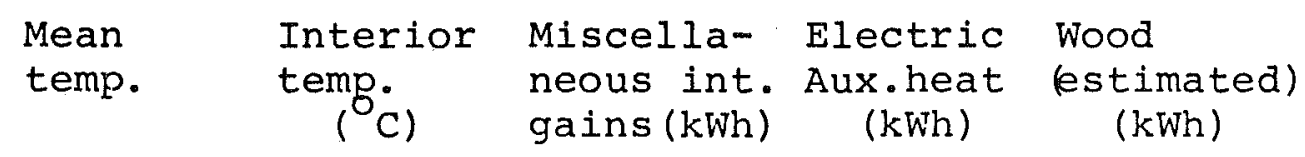

\begin{tabular}{|c|c|c|c|c|c|}
\hline JAN & -0.8 & - & 872 & - & 3600 \\
\hline FEB & 4.1 & - & 452 & - & 3600 \\
\hline MAR & 3.2 & 14.10 & 443 & 800 & - \\
\hline APR & 6.3 & 16.27 & 451 & 330 & - \\
\hline MAY & 14.8 & 20.20 & 525 & - & - \\
\hline JUN & 14.6 & 20.40 & 498 & - & - \\
\hline JUL & 20.2 & 23.20 & 499 & - & - \\
\hline AUG & 17.1 & 21.50 & 508 & - & - \\
\hline SEP & 16.4 & 22.20 & 423 & - & - \\
\hline OCT & 11.7 & 19.00 & 478 & - & - \\
\hline NOV & 3.6 & 18.70 & 417 & 56.80 & 3600 \\
\hline DEC & 5.6 & 17.60 & 414 & 273.00 & 3600 \\
\hline JAN & 0.2 & 17.60 & 452 & 405 & 3600 \\
\hline$F E B$ & 3.5 & 19.80 & 431 & 33 & 3600 \\
\hline MAR & 4.4 & 18.80 & 433 & 333 & 2700 \\
\hline APR & 6.3 & 20.20 & 389 & 22 & 2700 \\
\hline MAY & 9.4 & 19.70 & 363 & - & 2000 \\
\hline JUN & 14.0 & 20.20 & 319 & - & 750 \\
\hline JUL & 13.9 & 19.30 & 359 & - & 85 \\
\hline
\end{tabular}




\section{$\underline{5 . \text { Comments }}$}

Monitoring of the three passive solar buildings and subsequent interpretation of the data have been difficult, as is often the case with occupied structures. In the house at "Begnins", for example, it is difficult to measure the amount of heat generated when the fireplace is used. Further, the use of the wood stove in the kitchen generates so much heat that concurrent solar gain is not useful. The task of calculating a solarsaving fraction from the measured data is therefore not a clear cut procedure given the use patterns of the house.

The performance of the Trombe wall of the "Renens" house revealed the importance of thermally isolating the Trombe wall from the basement wall (not done in this example). The house, none the less, provided valuable measured data to check various mathematical models.

After eighteen months of measurement the performance of the "Geneveys/ Coffrane" house appears impressive. The good insulation and tightness of the house drastically reduce the heating load. The greenhouse and direct gain meet more than 60 percent of the heating load, 24 percent is provided by the internal gain. Due to the high efficiency of the passive system and the small load, the active system participates in meeting only 4 percent of needed space heating. This small fraction drastically increases the pay-back time. The data being collected from the greenhouse will be a valuable contribution to the knowledge on greenhouses as passive solar elements in the Swiss climate. The two active systems have provided valuable information in areas such as:

- collector efficiency under in-service conditions

- charging and discharging efficiencies of the storage

- floor heating dynamics. 


\section{Publications}

Morel, N., Perrin, G.-R., Razafindraibe, A. "Passive Solar House Begnins", Ecole Polytechnique Fédérale de Lausanne, Dept. Physique Lausanne, Switzerland, June 1981

Morel, N., Perrin, G.-R., Razafindraibe, A. "Passive Solar House "Les Geneveys"", Ecole Polytechnique Fédérale de Lausanne, Dept. Physique Lausanne, Switzerland, June 1981

Razafindraibe, A., Faist, A. "Acquisition and treatment of data collected from solar houses", Building Energy Management, Porto, Portugal, May 1980

Suter, P., "Instrumentation for the Monitoring of solar installations" Institut Thermique Appliquée EPFL, Building Energy Management, Porto, o. Fernandes, A. Faist, J. Woods) May 1980

Hadorn, Chuard, D., "Simulation d'une maison solaire avec le programme TRNSYS", 2ème Symposium sur la R \& D en Energie solaire en Suisse, EPF Lausanne, October 1980

Calatayud, C., Nilsson, M., "Travaux AIE, Installations actives. Validation", 2ème Symposium sur la R \& D en Energie Solaire en Suisse, EPF Lausanne, Oktober 1980

Perrin, G.-R., "Reporting Format" GRES - EPFL, February 1980

Perrin, G.-R., "Procédés de mesures sur systèmes solaires passivs" GRES - EPFL, May 1980 


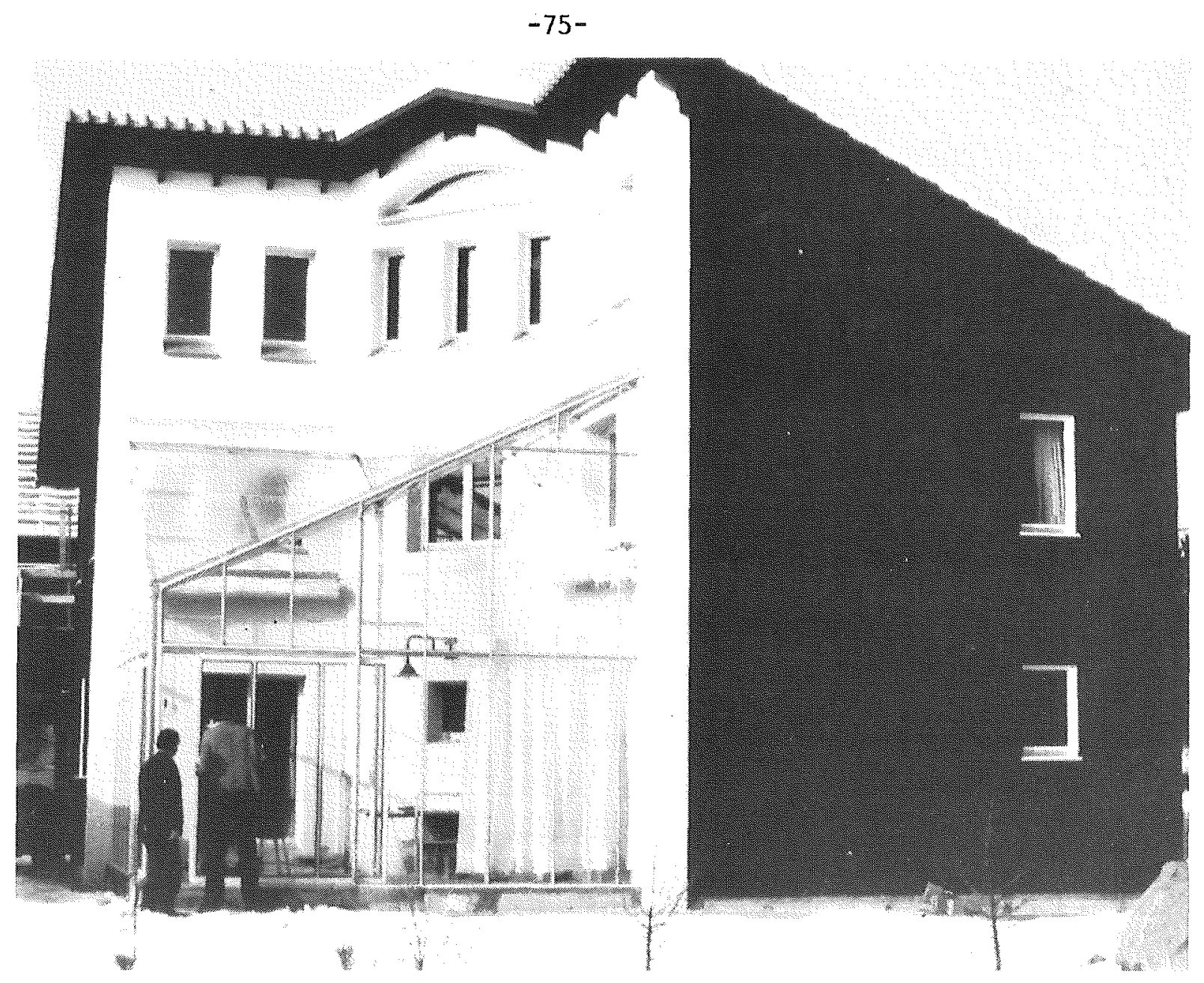

2.9 AN ATTACHED GREENHOUSE NEAR ZUG

\section{BACKGROUND}

A two story attached greenhouse was built as a passive element of a new house near Zug. The designer of the house, a student at the ETH-Z has subsequently instrumented the greenhouse to monitor the actual heat contribution of the greenhouse and the comfort conditions it achieves. The monitoring was begun in March of 1981. The principal contact for the project is Mr. I. Möschlin, at Klingenstrasse 35, CH 8005 Zürich, Switzerland. 


\section{Objective}

- Collect data on surface temperatures and air temperatures of a greenhouse in order to evaluate its energy and comfort performance.

- Collect data on the surface temperature of the wall above the greenhouse to evaluate the benefit of the greenhouse relative to the wall alone without a greenhouse.

\section{Approach}

In order to monitor the greenhouse twelve sensors were installed as follows :

$\begin{array}{ll}\begin{array}{l}\text { Sensor } \\ \text { Number }\end{array} & \text { Location } \\ 1 & \\ 2 & \text { Tiled stove(1) outer surface temp. } \\ 3,4 & \text { Living rm. air temp. } \\ 5,6 & \text { Mass wall interior surface temp. } \\ 7 & \text { Mass wall sunspace surface temp. } \\ 8 & \text { Mass wall exterior surface temp. } \\ 9,10 & \text { Sunspace floor temp } \\ 11 & \text { Sunspace air temp. } \\ 12 & \text { Ambient temp. }\end{array}$

\section{Status}

Data collection for a two month sample period has been completed and the strip charts from the twelve point recorder are now being evaluated.

(1) a Tiled stove is a ceramic tile wood fired oven used for space heating 


\section{Example Results}

The following two curves are plots from measured data from the 16th of February, 1981.

Figure 26 illustrates the effect the greenhouse has on the surface temperature of the south wall. The upper curve which is the wall in the greenhouse is ten to twelve degrees $C$ warmer than the temperature of the same wall at a location above and outside the greenhouse shown in the lower curve.

Figure 27 shows the greenhouse air temperature in comparison with outside air temperature and relative solar radiation. The latter term refers to temperatures recorded by a temperature probe mounted on a black metal disc mounted vertically in the greenhouse. No attempt was made to calibrate the temperature to solar radiation in absolute terms. Noteworthy are the lag between the beginning of solar gain and greenhouse temperature rise, and the almost immediate drop in the greenhouse temperature occurring as solar gain drops off for the day. The lag in the morning can be explained by the fact that the greenhouse faces south and west, and therefore received only oblique morning sun. The immediate drop in temperature in the evening is due to the minimal contribution of the thermal mass of the wall, and the lack of any night insulation.

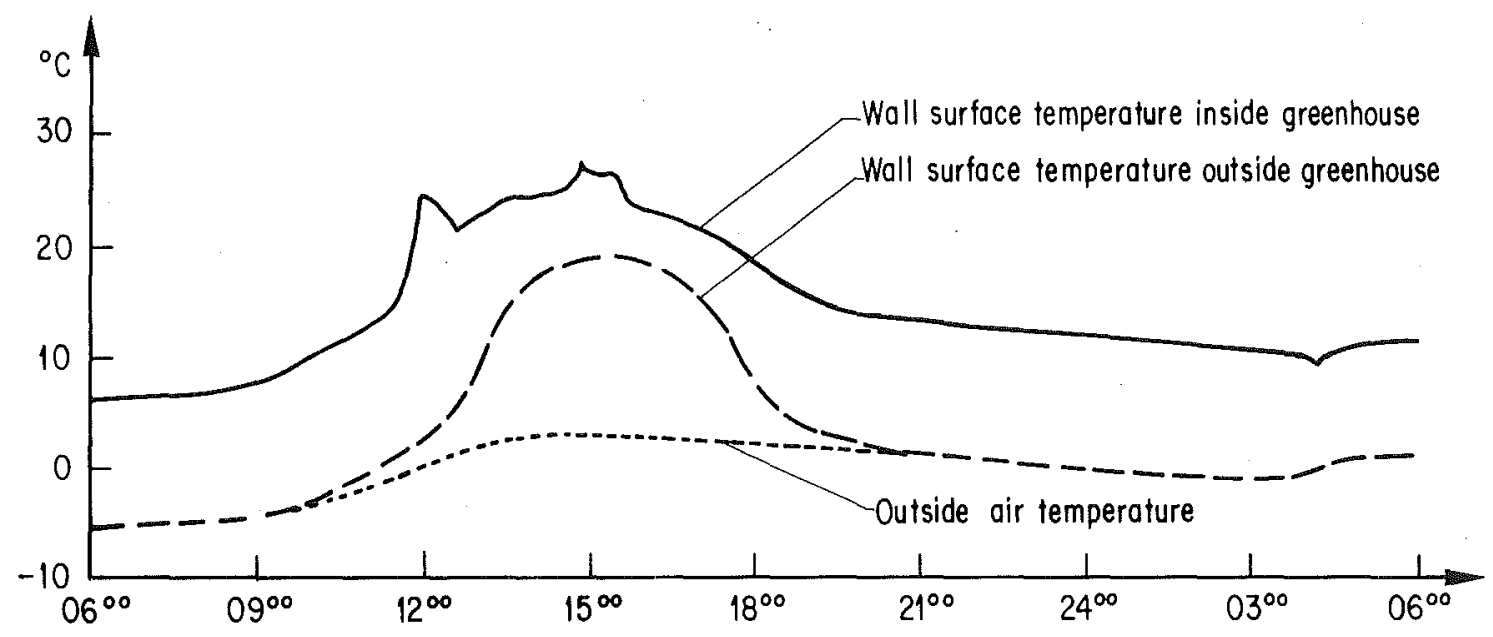

Fig. 26 Möschlin House Wall Surface Temperatures 


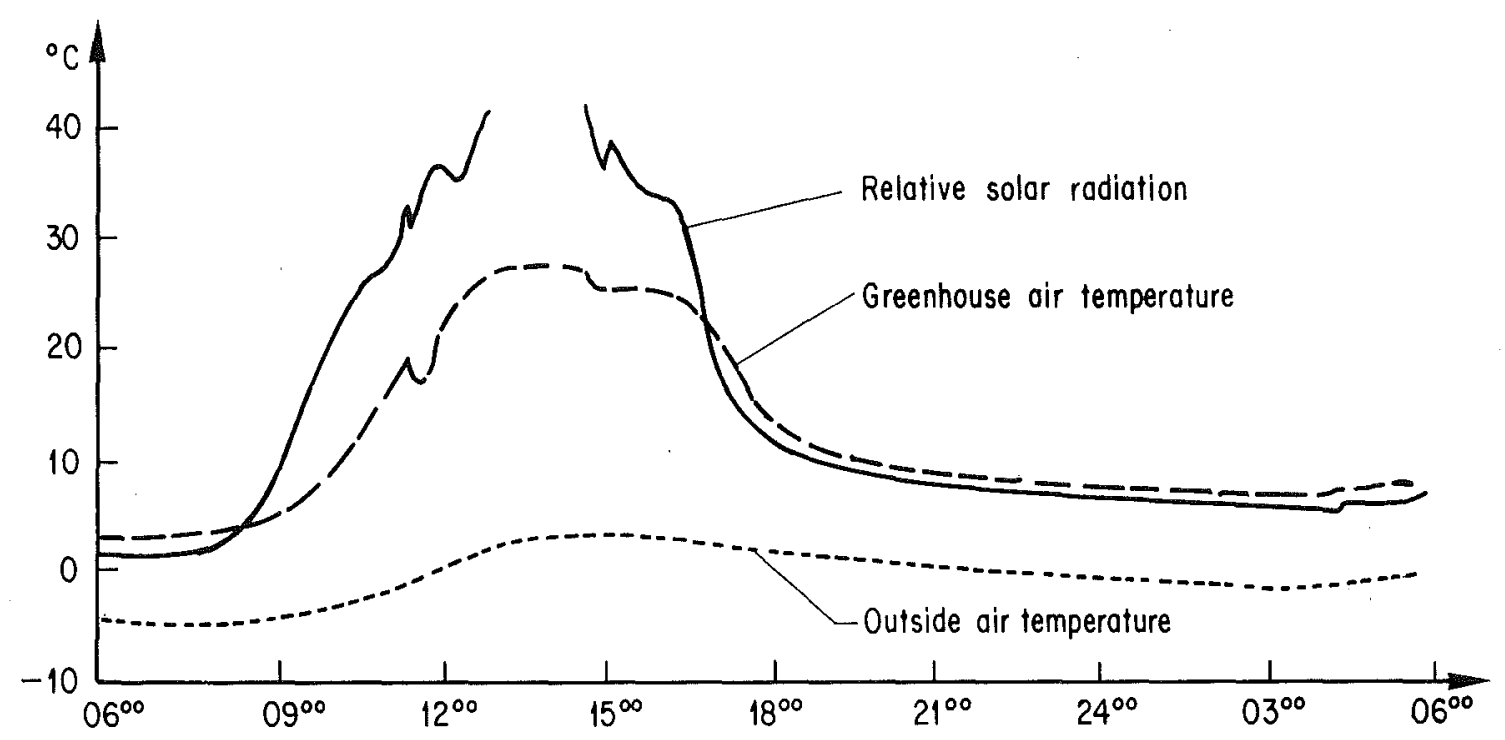

Fig. 27 Möschlin Greenhouse Air Temperatures

\section{$\underline{\text { 5. Comments }}$}

While data were collected for only a two month period, this project provides a useful reference point which when added to data from other projects will permit insights on attached greenhouse energy performance.

The white wall surfaces as they exist today probably reflect as much as $2 / 3$ of the solar radiation back out through the glass. A dark color would be better for absorbing solar gain. The designer's reason for the light color was to minimize the number of days when the greenhouse would be overheated to the point of being uninhabitable. A light colored fabric could be unrolled down the facade during the summer to achieve the same 
objective. A month of data collecting in the summer would also be useful to assess comfort problems. The loss of use of the space occupied by the greenhouse during the summer would certainly be a heavy cost.

Night insulation would also be an interesting variable to examine. The greenhouse is presently ribbed plexiglass double glazing and has a large sky exposure. How night insulation could be fitted to the complex geometry of the roof is clearly a problem, however.

A final worthwhile exercise would be to calculate how optimal the existing glass orientation is for the local climate. The designer's personal experience with the region indicated that mornings are typically overcast. The majority of hours of sunlight occur in the afternoon. A computer analysis of climate data for the region on a month-by-month basis could substantiate this belief as well as provide useful design data for calculating the benefit of west-facing glazing versus merely providing a well-insulated opaque wall to the west. 


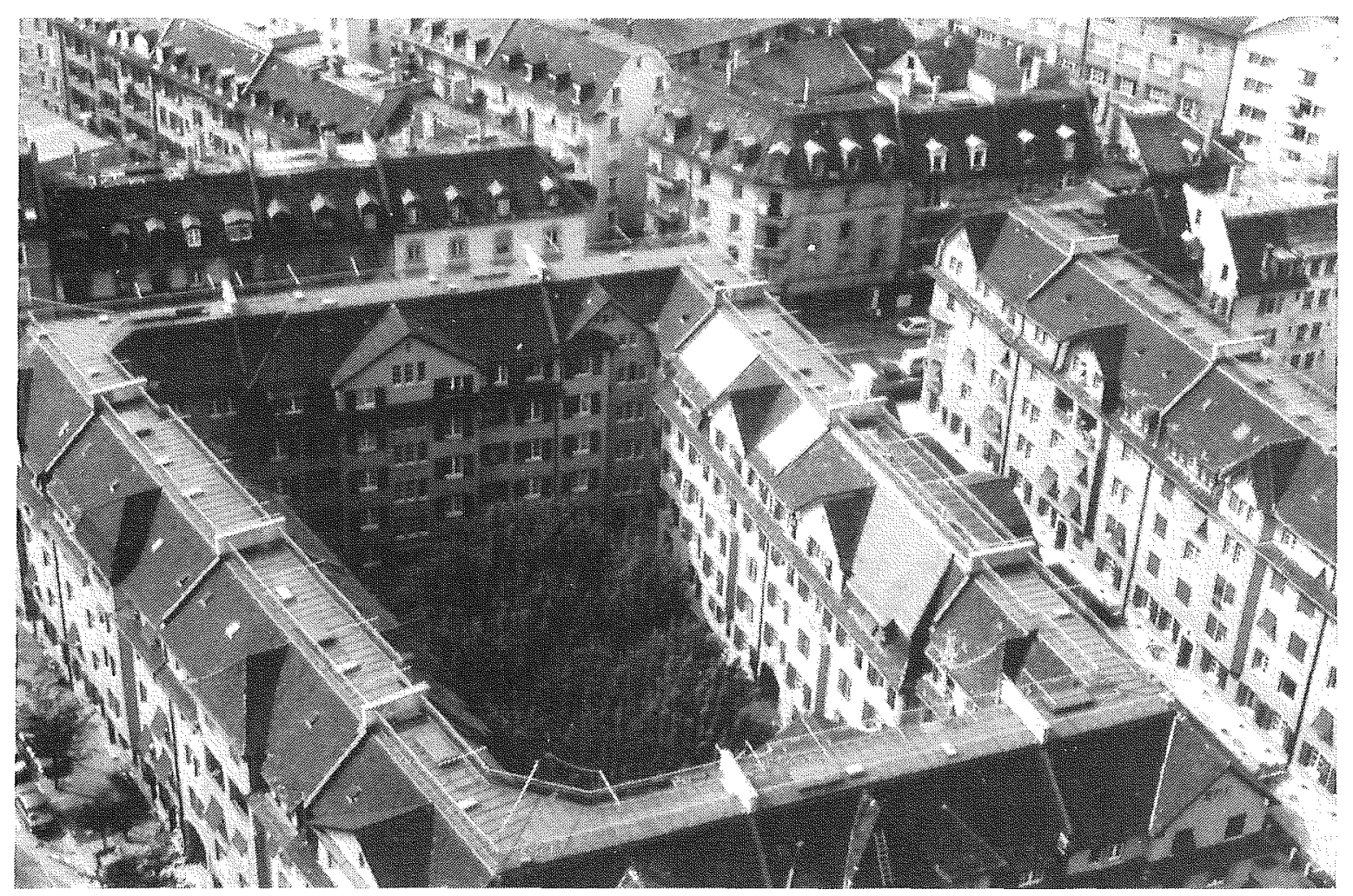

\subsection{LIMMATSTRASSE APARTMENT BUILDING RETROFIT}

\section{BACKGROUND}

An apartment complex in Zürich was retrofitted by the city to improve comfort conditions. The project provided an opportunity to measure the extent that standard retrofit practices actually do improve comfort. In addition, a number of alternative heating systems were installed to experiment with their effectiveness under "in-use" conditions. Included were various active solar systems, heat exchanger systems, a gas powered heat pump system, and a complex highly individual heating control system.

The project was begun in 1976 and is scheduled to be completed in 1982 . Dr. Jürg Gass of the Swiss Federal Laboratories for Material Testing is the contact for technical information. 


\section{Objectives}

- Measure the energy-consumption and possible energy-saving resulting from solar and heat pump systems and conservation measures.

- Investigate the influence of different temperature regulation systems on avarage room temperature.

- Compare the performance of "under-roof" and "on-roof" solar heat absorbers .

- Collect statistical data on domestic hot water consumption.

- Investigate possible energy savings from thermostat night setback of the heating.

\section{Approach / Method}

Four of twenty five, seventy-year old apartment blocks are being measured. The four units all have a similar orientation and identical layout.

The shell of block " 0 " has been unmodified to provide a reference case. only the interior and the plumbing installations have been renovated.

The building envelope heat losses of block "1" have been substantially reduced by replacement windows with triple glazing and added insulation (value ca. $0.5 \mathrm{~W} / \mathrm{m}^{2} \mathrm{~K}$ ) on north walls. Thermostatic valves have been installed on radiators in south-facing rooms. On the roof are $24 \mathrm{~m}^{2}$ of double-glazed flat-plate collectors with a $1.8 \mathrm{~m}^{3}$ storage for domestic hot water.

Block " 2 " has been retrofitted with superior insulation (value ca. $\left.0.4 \mathrm{~W} / \mathrm{m}^{2} \mathrm{~K}\right)$ on all walls.

A microprocessor-controlled heat regulation system allows individually controlled temperature programs ( 4 daily changes) for each room. Finally, a gas engine powered heat-pump provides heat for space and water heating by extracting heat from: 
1) a system of roof solar absorbers (2 $\mathrm{km}$ of plastic tubing) divided into 2 systems, one lying flat on top of the roof, the other lying under the roof tiles. Both are connected to low-temperature storage tank

2) a gray water* holding tank.

3) the air in the heat pump gas engine room.

4) the coolant of the gas engine which drives the heat pump.

5) the exhaust from the gas engine.

Reference Building

Typ 0

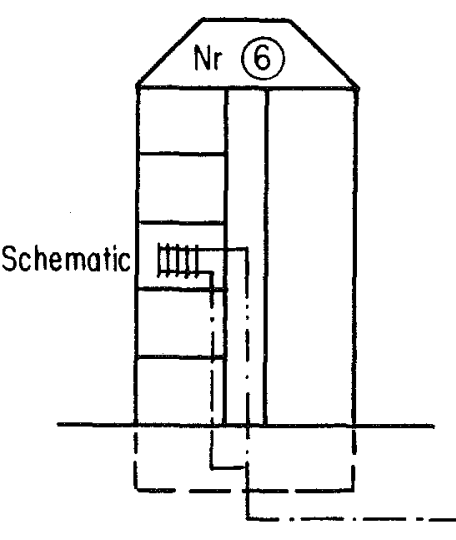

Normal Building

Typ 1

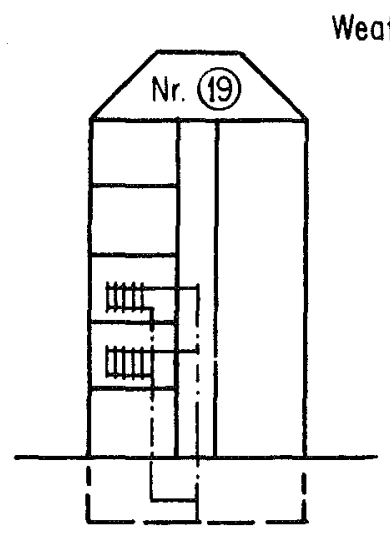

Normal Building

with solar collector

for worm water

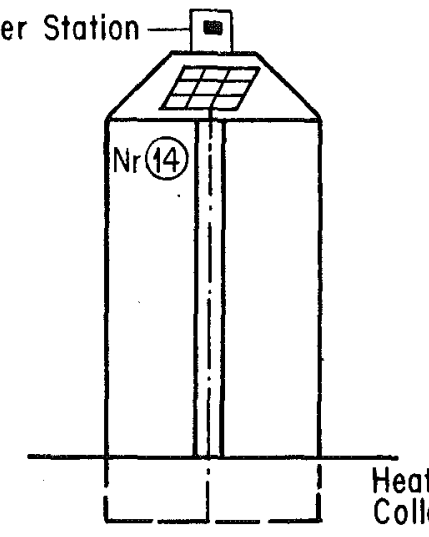

Experimental Building with heat collection Typ 2

Fig. 28 Overview of Measuring System

Data collection is controlled by a microprocessor and programmed through a video-terminal. Data are recorded on a magnetic casette-tape recorder with a capacity of 1.8 MBytes per casette.

This unit is located in one of the type 2 apartments, which serves as a central data collection station connected to all the other apartments. The parameters measured are:

* Gray water is waste water from sources other than toilets or urinals. 
1) Weather:

- Air-temperature

- Global radiation-horizontal

- Diffuse radiation-horizontal

- Global radiation on collectors

- Wind speed

2) Block 0 (Reference) and Block 1 (Conservation)

- air temperature in the basement, attic, two stairwells, and twelve apartment rooms

- return water temperature of three radiators

- heat supplied for space heating

3) Block 1 Solar

Heat gain from the solar collector, heat consumption for domestic hot water for each apartment, and the city water inlet temperature.

4) Block 2 (Heat collection)

- air temperature in the attic, hall and three apartments

- return temperature for every radiator

- heat gain from the two roof tube collectors

- temperatures of the domestic hot water preheat boiler, gray water holding tank water, heat pump engine coolant, heat pump engine exhaust, and heat pump engine room air

- space and water heat

The heat-collection system has 20 temperature-sensors, 9 water flow meters, 1 ultrasonic flow meter in the grey water circulation, and 1 gas-counter. All temperature measurements are momentary hourly values

A monthly standard evaluation of the data is made, to provide a continous check of the data throughout the two years of measurement. Important parameters are evaluated at 10 day intervals. 


\section{Status}

Collection of data was started in March 1980. A computer program has been written and is now in use to assemble the raw data from the cassettes and produce period summaries of climate data, building interior temperatures and heat use.

Evaluation of the various systems from the operating data is in progress. Final analysis will begin upon the completion of the measurement phase in 1982 .

\section{Example Results}

Figure 29 illustrates the reduction of required heating resulting from adding insulation to the north wall and replacing the window/storm windows with new triple-glazed window. It is interesting to note that the measured heating requirement in the spring was greater for a retrofitted apartment than for an unretrofitted apartment. Possible explanations for this include occupant factors, the slightly different orientation of the two buildings, and the effect of triple glass reducing solar gain during a period when solar and internal gains begin to match heat load.

Figure 30 compares two solar absorber systems for heating water. One system is simply flexible black plastic tubing laid out on a flat roof. The second is tubing run in the space directly beneath the roof tiles. Again, the curves are measured results. The data indicate that the under-roof absorber performs better in winter, while the above-roof absorber performs better in summer. This may be explained first by the fact that the above-roof absorber lies flat while the under-roof absorber is on a south sloping exposure. The variation of summer and winter sun angles therefor help explain the difference in performance. 


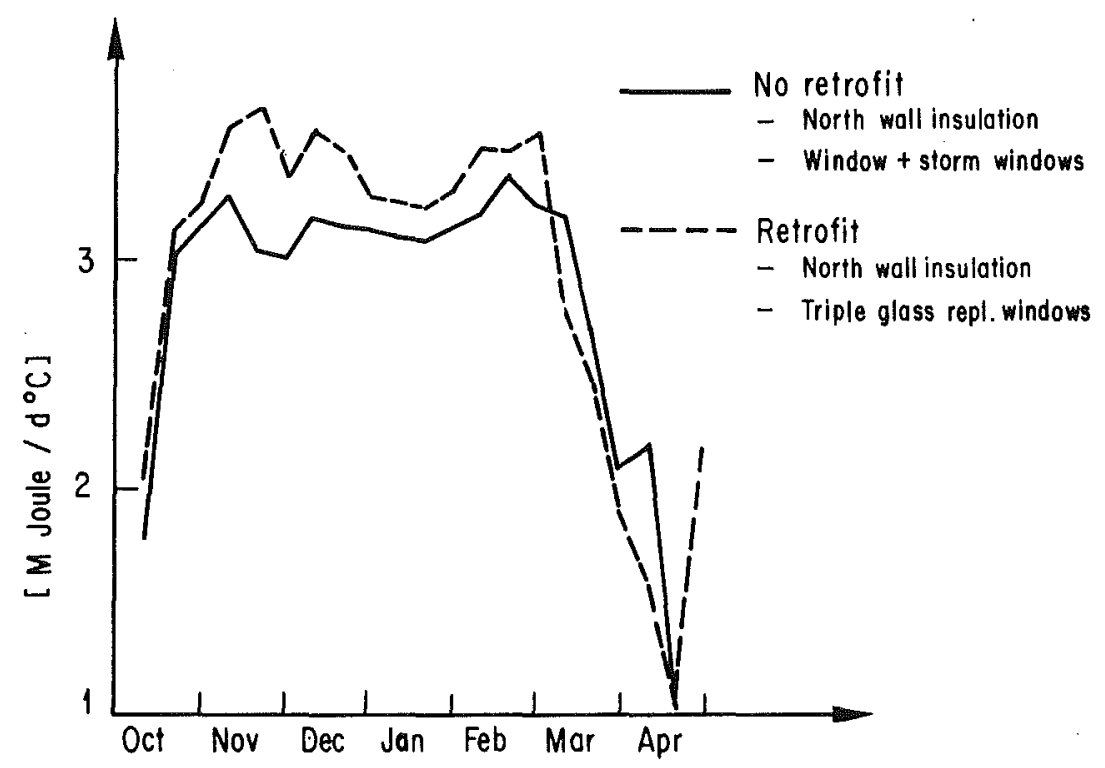

Fig. 29 Comparison of Heating Energy Use by Base Case and Retrofit Building

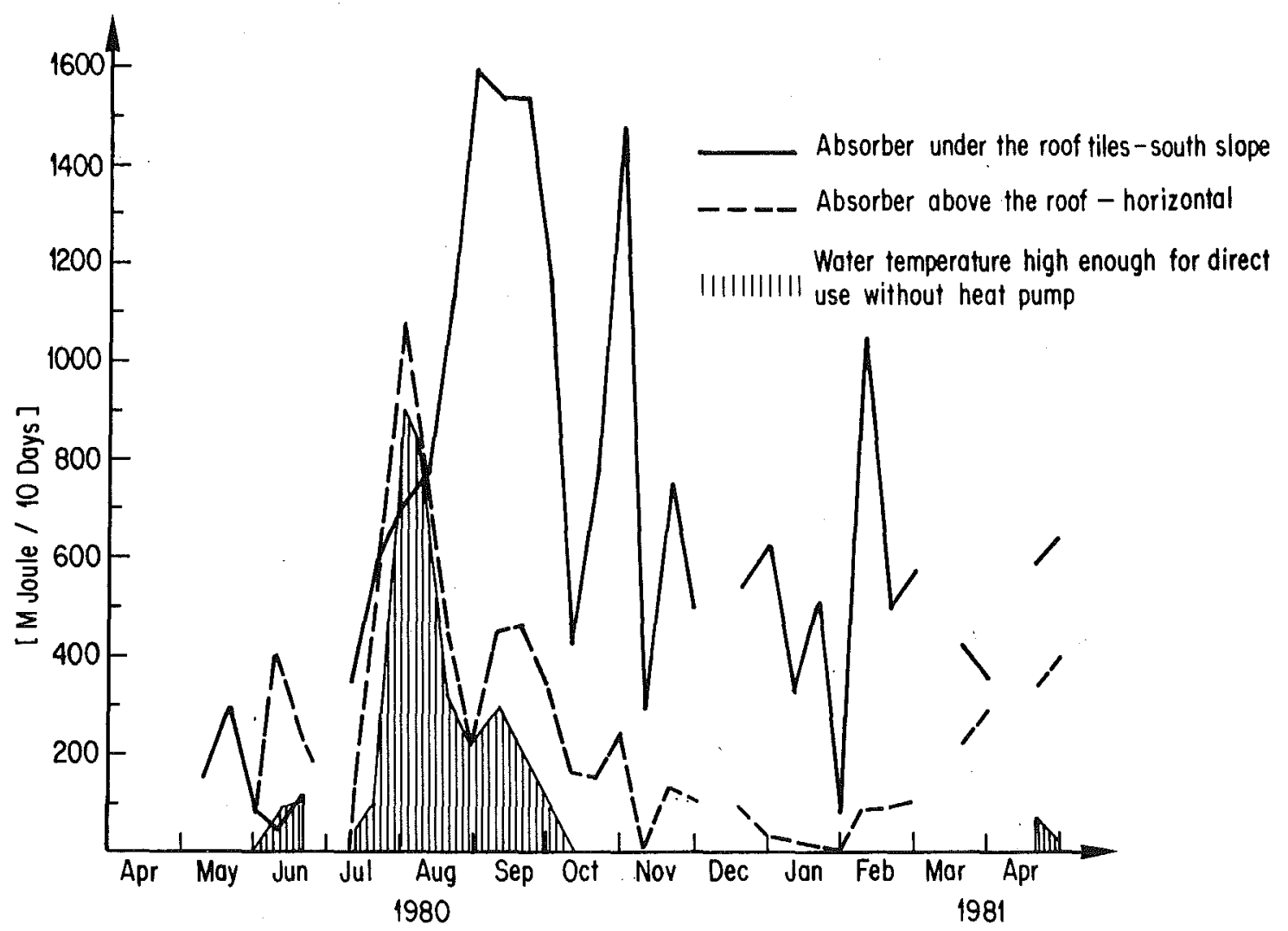

Fig. 30 Roof Solar Absorbers-Heat collected per 10 Day Intervals 
Figure 31 illustrates the monthly energy uses and energy sources for the apartment block with the combined solar and heat pump system. A direct correlation between ambient heat sources and the heat provided by the roof solar absorbers is not possible because ambient sources include heat recovery from gray water. This factor is extremely user sensitive. The monthly data presented in this figure are presented on an annual basis in Figure 32. Note that when the Consumed energy is divided by the purchased energy the result is 0.99 including all the system and distribution losses, and computed on an annual basis.

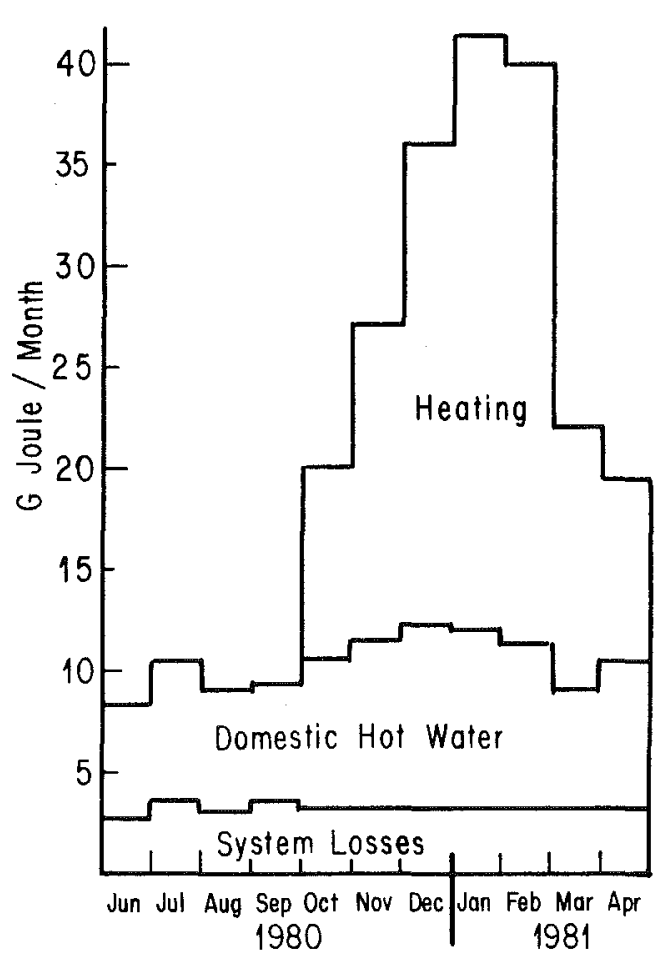

Fig. 31 a Energy Uses

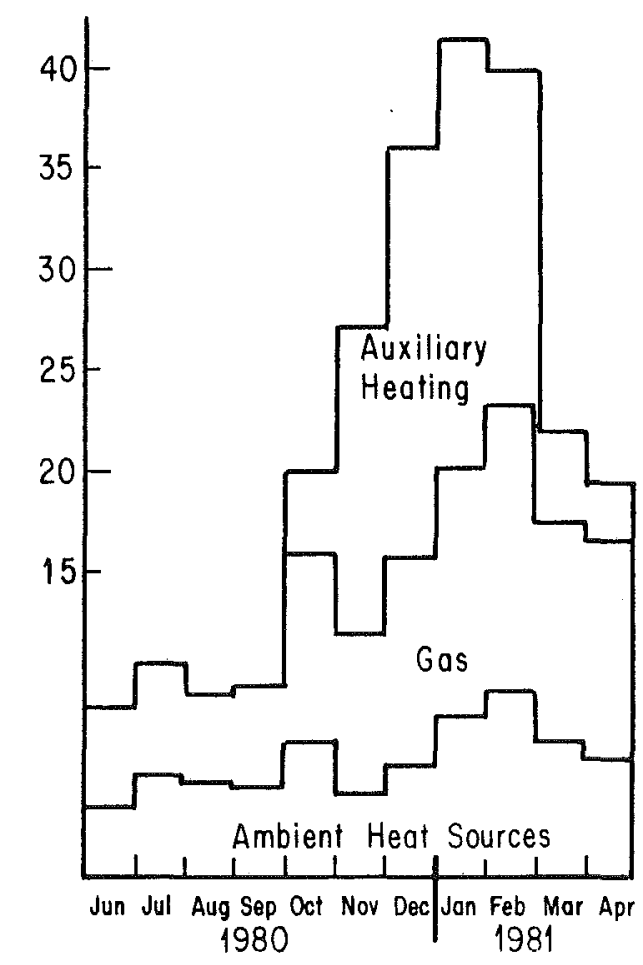

Fig. 31 b Energy Sources 


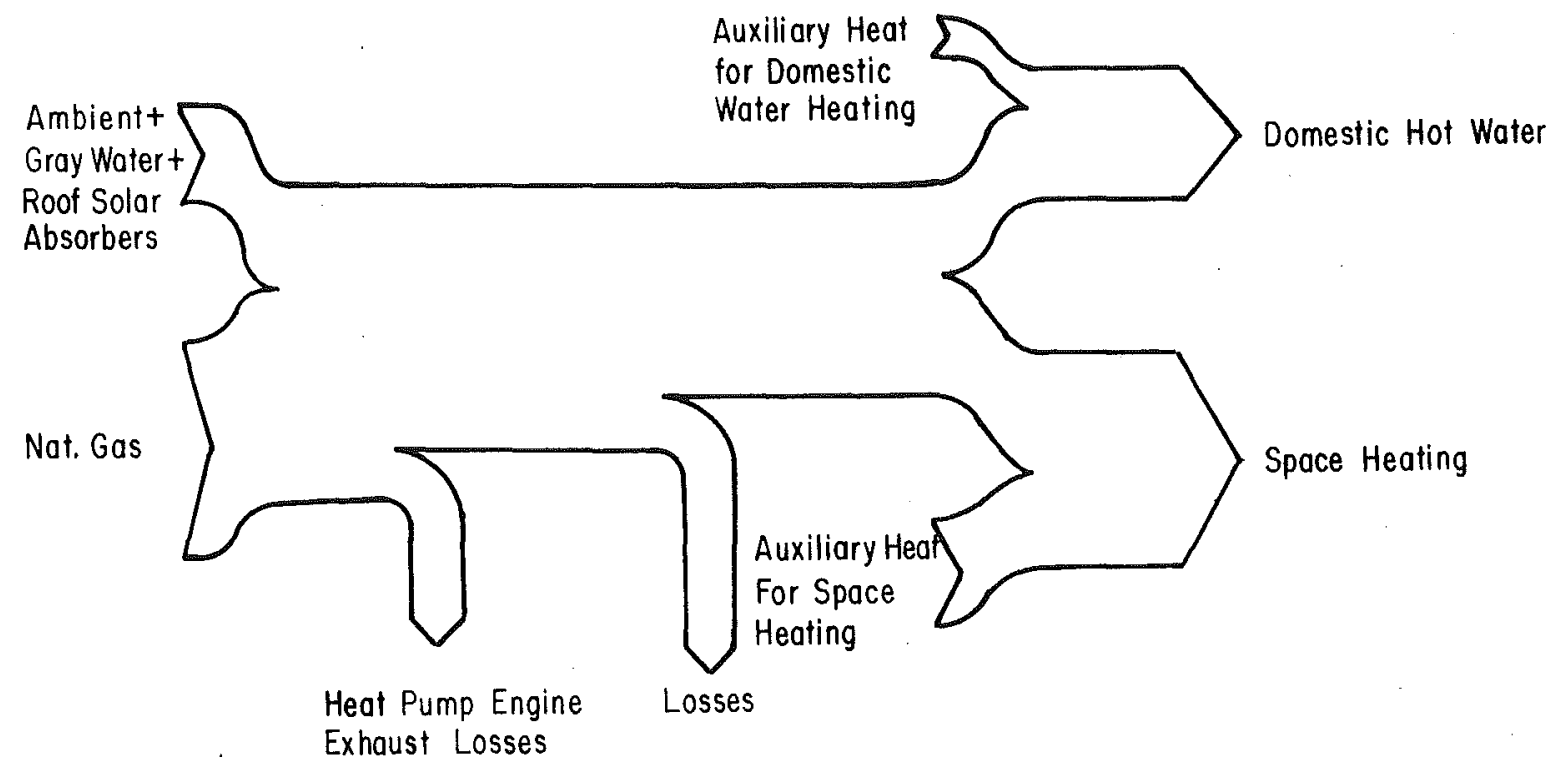

Fig. 32 Energy Flow Diagram for the Solar Retrofit Apartment Block

\section{Comments}

Data obtained from monitoring the Limmatstrasse project will permit an in-depth evaluation of the different retrofit strategies employed. Given the very large number of buildings retrofitted to conserve energy, it seems necessary to measure a sample of buildings to verify that the expected savings are being achieved. Limmatstrasse goes beyond providing a check on the savings possible from conventional retrofit and includes experimentation with new and highly complex alternative heating and water heating systems.

It would be useful to expand the project beyond the number of options actually implemented by computer-simulating a range of alternatives not implemented. Of particular interest would be a simulation series of passive solar retrofit alternatives. One such alternative might be replacing the south-facing roof slopes with glazing, thereby converting the attic into a greenhouse area.(Fig.33). Heat so collected could be used for clothes drying (clothes are presently dried on roof clothes lines, weather permitting) or for heating the apartments below. 
Other variations might include add-on solar air collectors appended to the building facade, addition of an experimental window night insulation system, or retrofit Trombe wall applications. On a grand scale, it would be useful to calculate the effect of building a space frame over the entire court space of one of the apartment complexes. The space frame could then be profiled in a series of triangular vaults with glazing to the south and opaque insulated roof to the north. The entire court space, rather than being merely more surface area for building envelope heat loss, could become a solar atrium. (fig. 34.) 


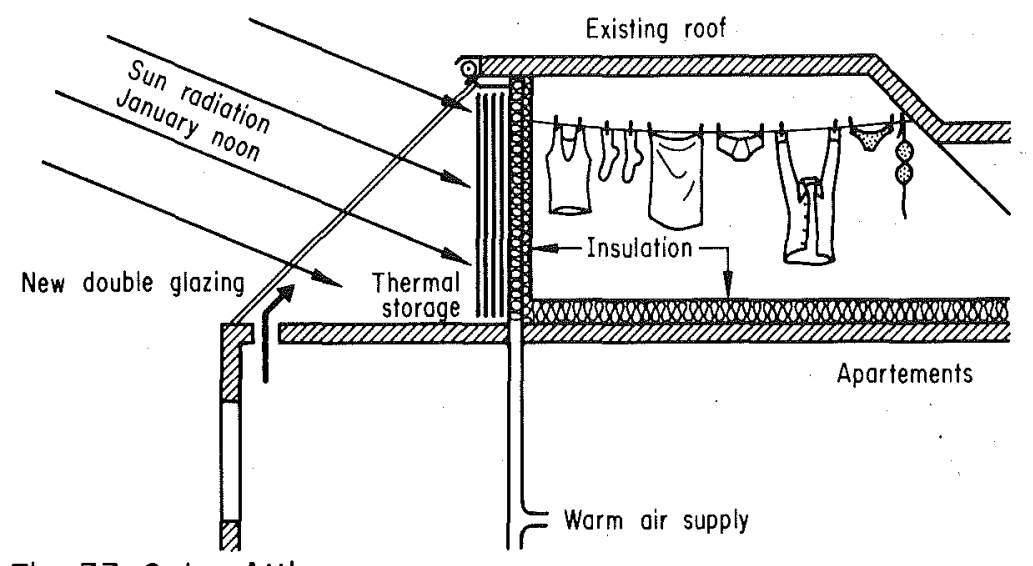

Fig. 33 Solar Attic

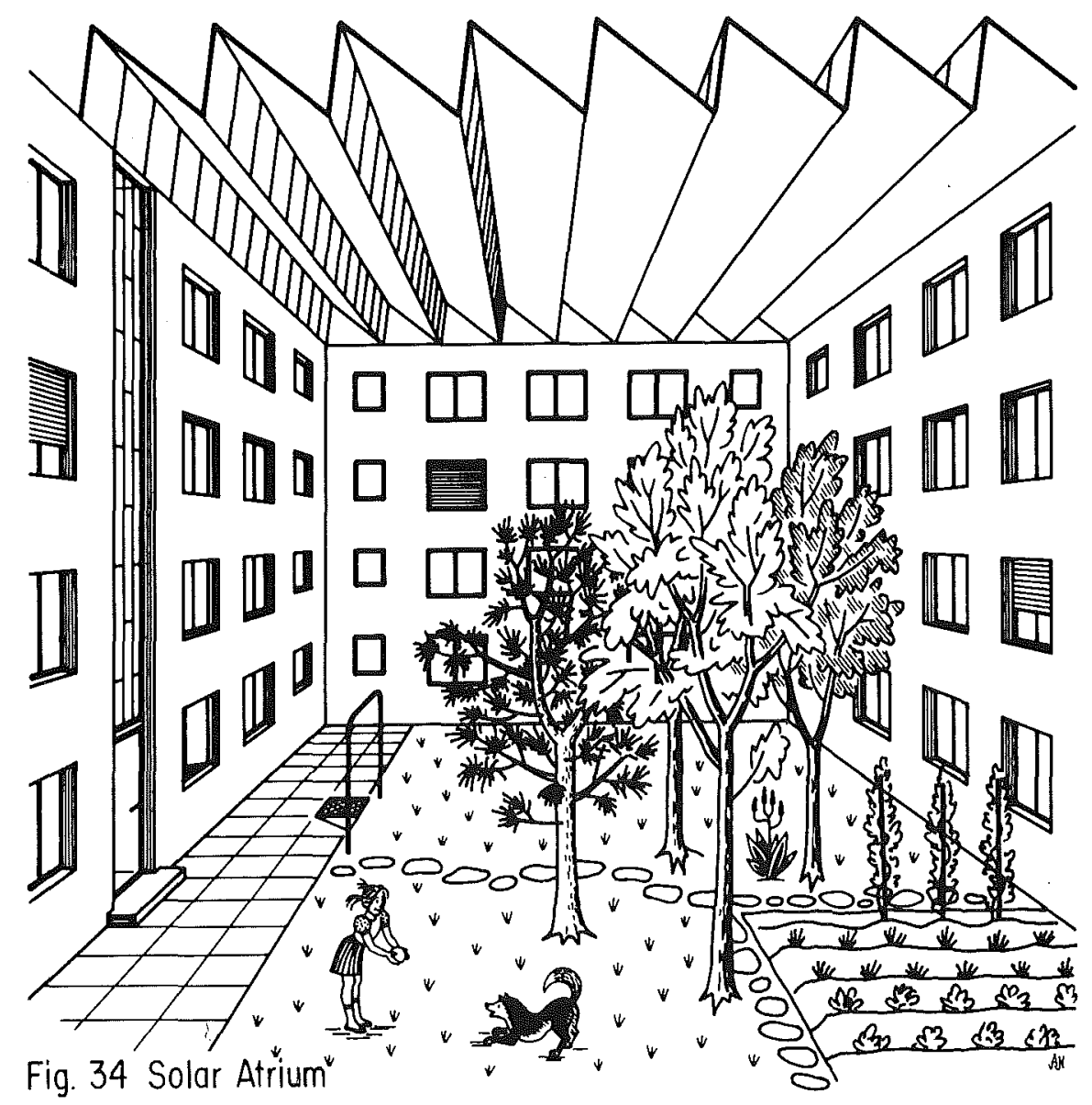


6. Publications

Brunner, C., Gass, J., Stachura, P. "Wohnkolonie Limmatstrasse Energie Sanierung" (Zwischenbericht: Messperiode 1980/81), EMPA, June 1981

Hartmann, P., EMPA-report Nr. 3643, "Umbau Wohnkolonie Limmatstrasse" Schweizer Ingenieur und Architekt Nr. 20/80, p. 470-476, Mai 1980,

Gass, J., "Messtechnische Ueberprüfung der Sanierung der Wohnkolonie Limmatstrasse", Erstes Schweizerisches Status Seminar: Wärmeschutzforschung im Hochbau, EMPA, 8600 Dübendorf, Oct. 1980. 


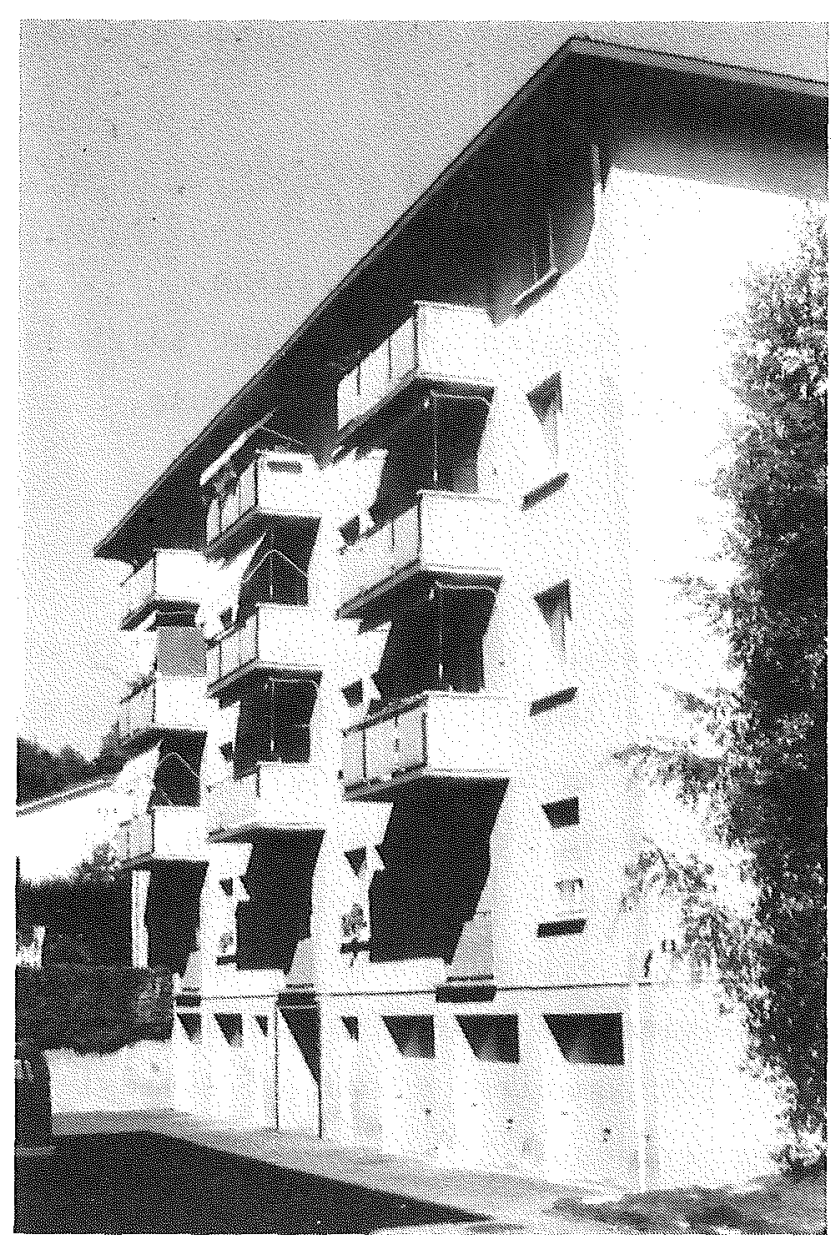

\subsection{CHAUMIERE APARTMENT BUILDING}

\section{BACKGROUND}

A four story, 24 unit apartment building in Lausanne has been instrumented to provide data for calibrating energy calculation models. Dr. P. Favre of the Federal Institute of Technology in Lausanne initiated this project in 1979. Data collection will be continued for two years, ending in 1982. Because of the extended period of measurement, special attention was given to make the sensors as inconspicous as possible. One apartment unit is unoccupied to provide a base case for estimating occupant influence on heating demand. 


\section{Objectives}

- Provide detailed data on the thermal balance of the building.

- Calculate the energy consumption of an occupied and a vacant apartment in order to evaluate the occupants' influence on the energy use.

\section{Approach / Method}

A representative four story apartment building belonging to the city of Lausanne was selected for measurement. The selection of the building to be instrumented was difficult. A list of possible buildings was developed on the basis of location, size, representativeness of design, and rent levels. The majority of the possible buildings subsequently had to be eliminated because of landlord or occupant opposition to "such an intrusion of privacy". Only the town of Lausanne as owner finally agreed to have one of it's apartment buildings instrumented. 17 out of 24 residents agreed to participate in the experiment.

The building, which dates from 1957 is a four story structure with six apartments on each floor. Brick walls $25 \mathrm{~cm}$ thick support reinforced concrete floors. The windows are double glazed.

Two kind of measurements are being made:

1) Dynamic measurements consisting of:

- interior and exterior wall surface temperatures

- heat flux through the walls

- temperature and water flow from and to the heating system

- room air temperatures

- interior climate (room air temperature)

- exterior climate (radiation, temperature, wind, humidity) 
2) Static measurements:

- determination of wall construction for theoretical evaluation of thermal characteristics

- window air tightness measurement

- infra-red photography of the building in order to provide a reference for evaluating data from the wall surface temperature sensors.

A vacant apartment has been instrumented more thoroughly. It will be normally occupied the second year of measuring. This will provide an example of the effects of occupancy on heating energy consumption.

\section{Status}

The data collection is fully in progress. A publication with results is available.

\section{Example results}

No sample results are available yet.

\section{Comments}

A comparaison of the results of this project to the Limmatstrasse apartment building in Zürich should prove interesting. Like the Limmatstrasse buildings, the Chaumière building will be retrofitted. It would be valuable to repeat the measuring after the retrofit. Of interest is the care given to making the sensors and wiring as inconspicious as possible. Wiring has been concealed in specially installed hollow moldings. Sensors were located in consideration of occupant furnishings to both minimize the intrusion and to reduce the liklihood of furnishings distorting the sensor output. For example, a wall surface temperature sensor subsequently obscured from the room interior by the placement of a massive cabinet would not permit a realistic representation of the wall's thermal performance. 


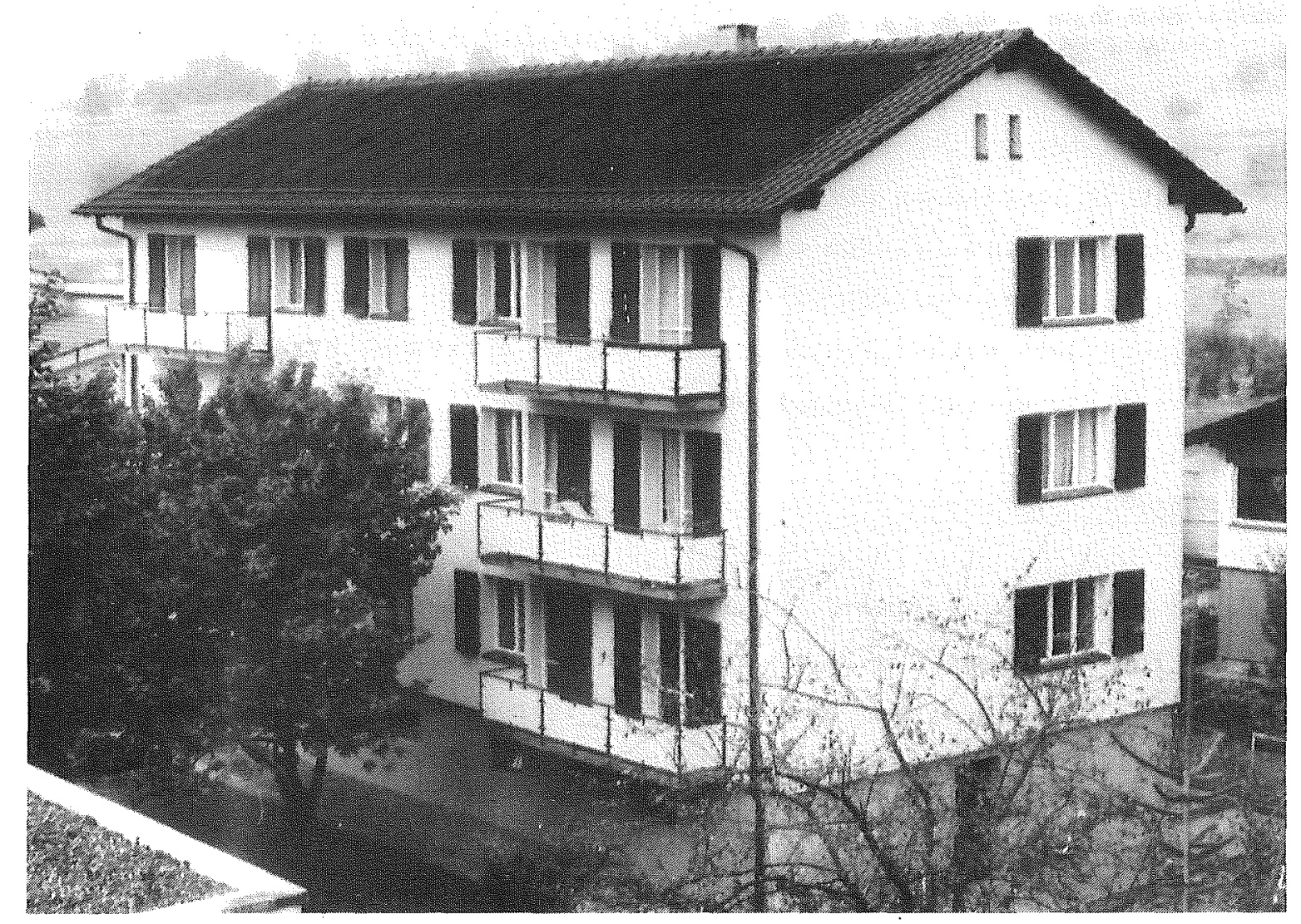

\subsection{ZUG APARTMENT BUILDING}

\section{BACKGROUND}

A three story building containing six apartments has been retrofitted to measure and demonstrate the energy savings possible given present technologies. The retrofitting consists of a low temperature solar absorber assisted heat pump, and added insulation and replacement windows to reduce losses. The first winter of data collection is now completed. The principal contact for the project is Dr. A. Stebler, Stiftung Sonnenenergiehaus, Zug. 


\section{$\underline{1.0 \mathrm{bjectives}}$}

- Evaluate the thermal and economic performance of a solar absorber assisted heat pump system, as used to heat a multi-family building.

- Develop innovative retrofit installation procedures given the constraint of continuous occupancy.

- Provide a demonstration of a succesfull application in order to stimulate wide introduction of solar heating.

- Collect data with electronic metering on apartment by apartment variation of heating energy consumption.

\section{Approach / Method}

Based on a set of selection criteria, an apartment block was chosen in Zug. The building is a 20 year old, three story structure with three 3-room and three 4-room apartments. It is a common building type in Switzerland with several identical buildings in the immediate neighborhood which will permit comparison.

Prior to the retrofit each apartment was heated by a wood burning oven. The resulting large temperature differences between rooms caused condensation damage to the poorly insulated walls.

The building was retrofited with $5-10 \mathrm{~cm}$ polystyrol exterior insulation and a central heating system. The U-value of the building shell, including conventional double glazed windows has been reduced to $0.44 \mathrm{~W} / \mathrm{m}^{2} \mathrm{~K}$. The low temperature solar absorbers consist of waterfilled black plastic pipe covering the entire roof as can be seen in the title photograph. A water to water heat pump extracts heat from the solar heated water and provides water at $50^{\circ} \mathrm{C}$ to each apartment for space heating. Figure 35 diagrams the system. 


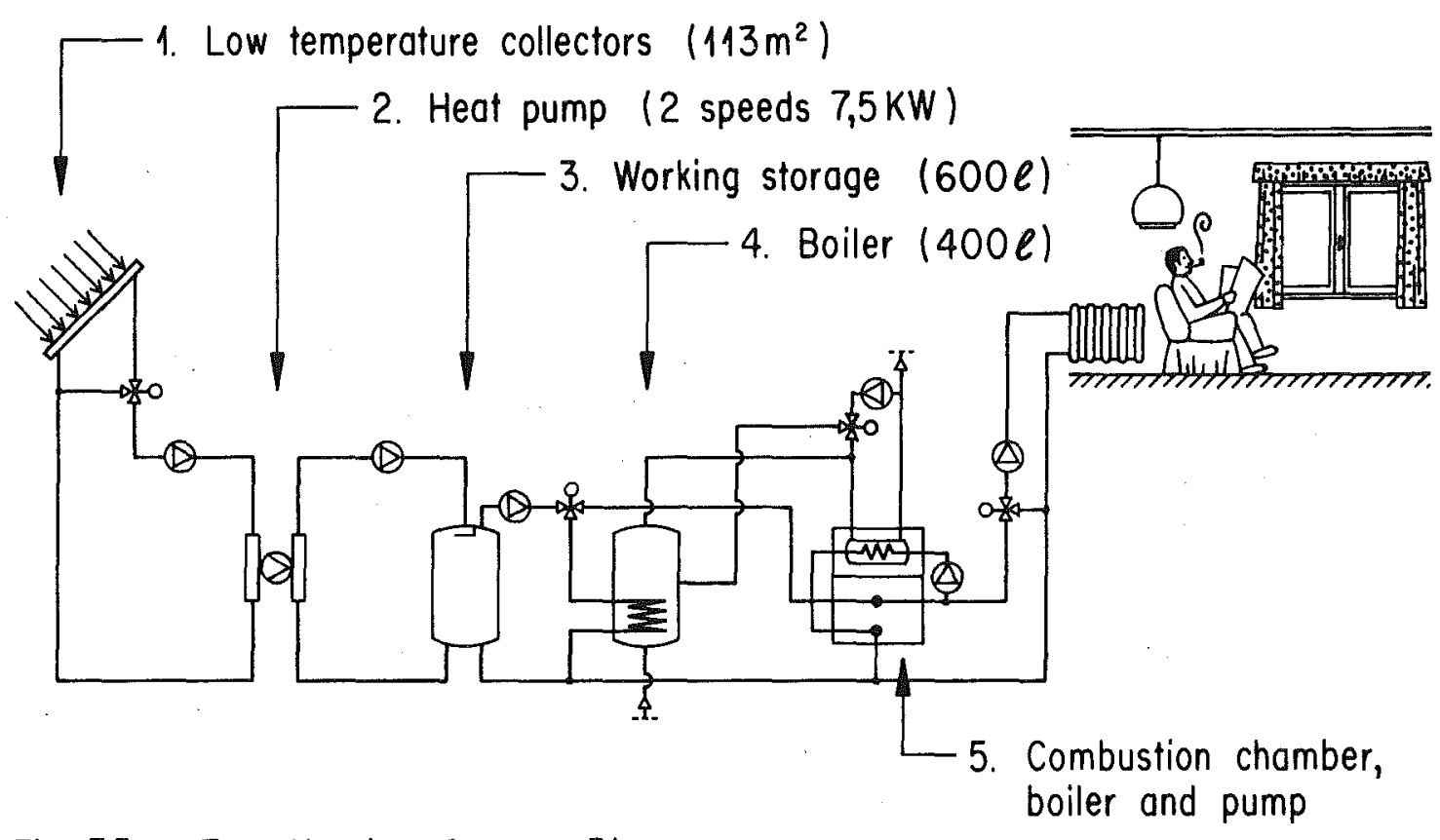

Fig. 35 Zug Heating System Diogram

\section{Status}

A11 the retrofit work has been completed. Results for overall energy consumption are available. Measurement will continue in order to get more precise information on the following:

- Individual apartment energy consumption

- Effectiveness of the heating system regulation

- Operational cost.

\section{Example}

Due to the added insulation the heating load has been reduced by 50 percent, or a savings of 5000 liters of oil per year. Initial estimation from the first six months of the solar system operation indicate oil consumption will be reduced by an additional 4000 liters/year compared to that which would have been required. Electricity consumption by the heat pump in bivalent operation is expected to equal the prevously used electric boiler's consumption. 
By adjusting the system to the different outside temperatures, electricity consumption could be maintained at between 140 to 115 percent of preretrofit use in monovalent mode.

\section{Comments}

The principle benefit of this project has been the demonstration of the major reduction of oil consumption possible through retrofitting a building using present technology.

An important aspect of this project is the informing of occupants of the energy consumed by their individual apartment. This feedback along with information on how to reduce energy demand, is expected to initiate substantial overall energy savings.

A valuable follow-up experiment would be to retrofit one of the neighboring similar buildings with a set of passive solar elements, such as a retrofit Trombe wall or attached greenhouses integral with the balcony construction. Such a parallel study would provide valuable data on the occupant satisfaction and cooperation as well as energy and economic performance of various retrofit strategies.

\section{Publicatons}

Schweizerisches Status Seminar Wärmeschutz-Forschung im Hochbau EMPA, 8600 Dübendorf, Oct. 1980

Schweizer Ingenieur und Architekt, Jan. and May 1981 


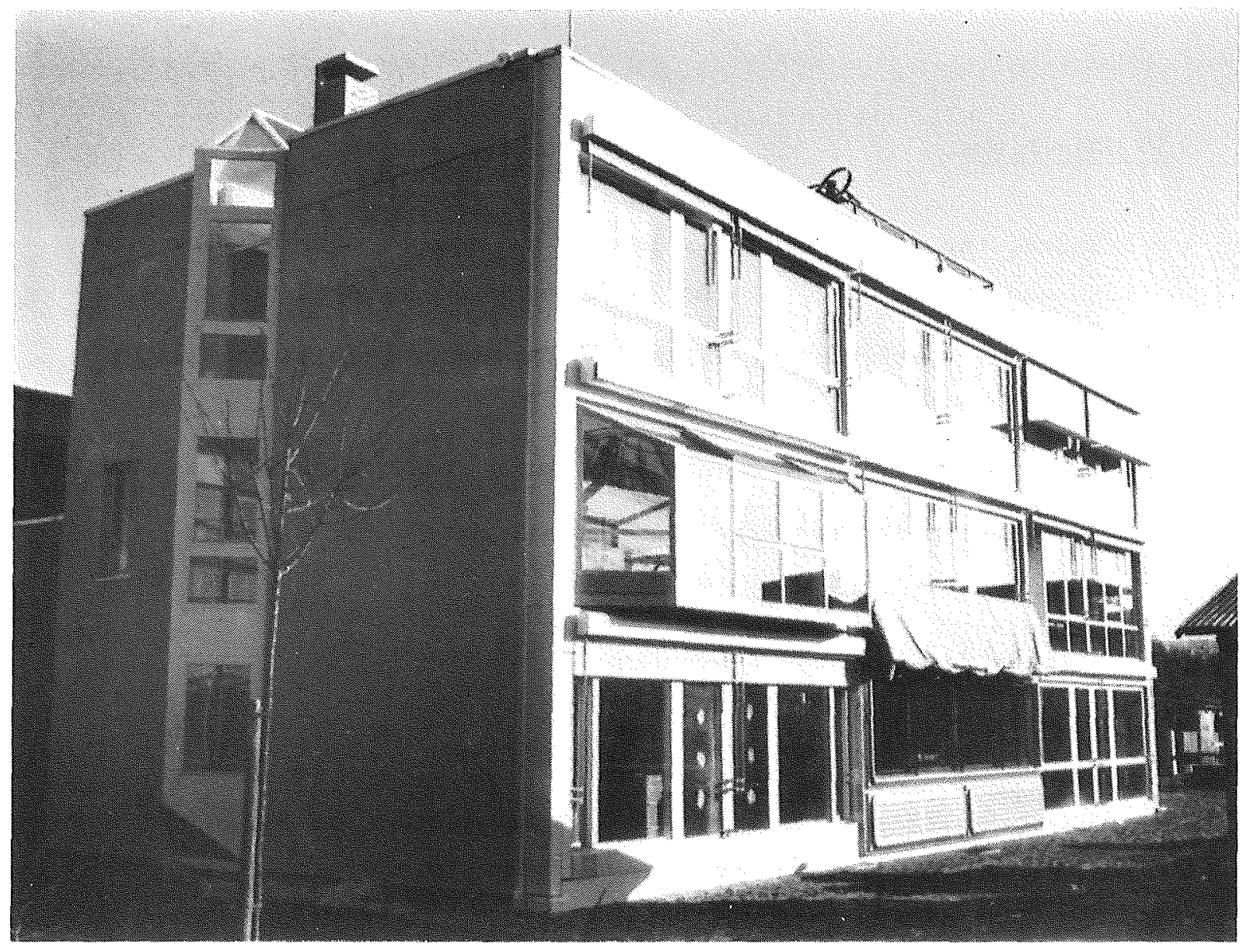

\subsection{LESO OFFICE LAB BUILDING}

\section{BACKGROUND}

A recently constructed laboratory and office building incorporates a three dimensional multi-story grid of thermally isolated rooms with interchangeable facade elements.It's purpose is to study the performance of a range of passive solar design strategies for non-residential as well as residential application. The building is occupied by the Solar Energy Laboratory of the Physics Department of the Swiss Federal Institute of Technology in Lausanne. The building was completed in 1981 with testing of the initial passive solar elements scheduled to last one to three years. 


\section{$\underline{\text { 1. Objectives }}$}

- Measure, the energy performance of a variety of side-by-side passive and hybrid designs under occupied building conditions.

- Study the interaction of the solar components with the auxiliary heating system.

- Provide monitored performance data for validating mathematical models.

- Enable extrapolations from the measured data to be made, as for example, for different climate conditions and for other building designs .

\section{Approach}

To allow simultaneous measurement of a variety of passive and hybrid designs, the building has been divided into nine thermally separated spaces. Each of the three isolated floors is divided into three isolated zones. The long axis of the building runs east/west so that each space faces south. Below are the plan and section of the building.

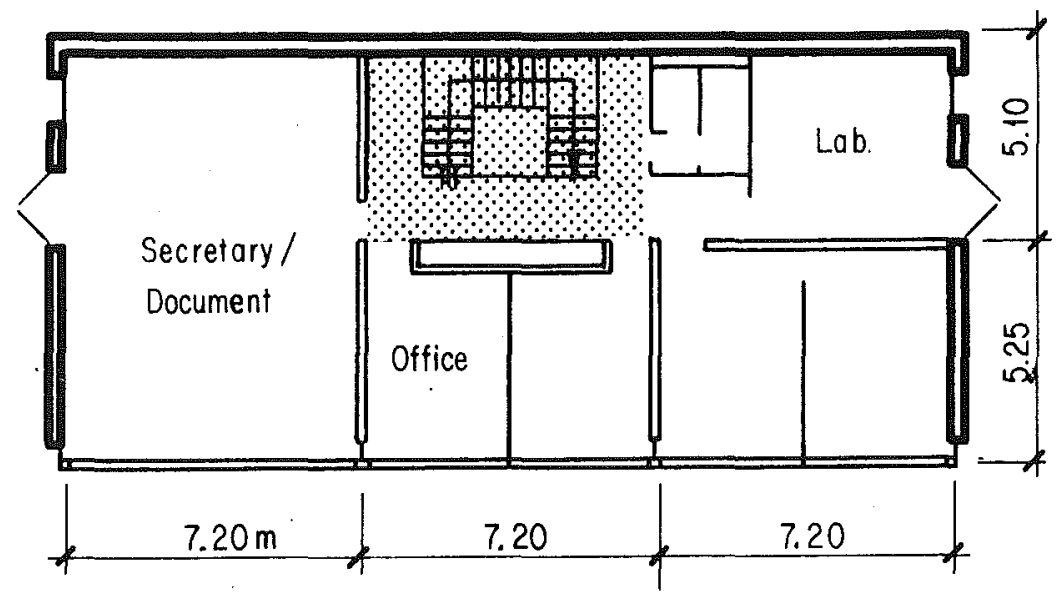

Fig.36 LESO Office/ Lab Plan and Section

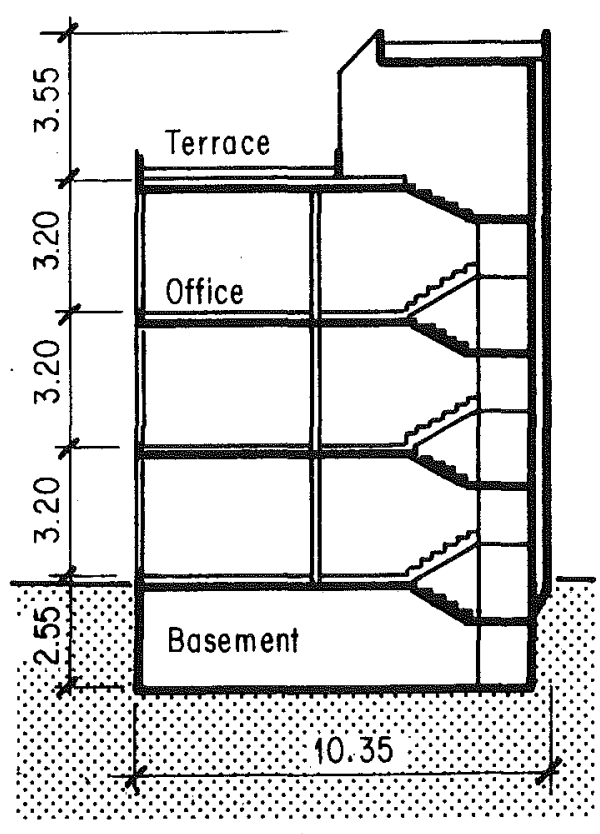


To assess the performance of passive systems, various modes of use are planned:

- auxiliary heating on, rooms occupied.

- auxiliary heating on, rooms unoccupied.

- auxiliary heating off, rooms unoccupied.

These various modes allow the performance of the building and passive systems to be evaluated integrally with the influence of both occupants and the auxiliary system, or independent of one or both of the latter. Data collection will be controlled through a central computer with high level language programming capabilities. Sixteen peripheral units contain 54 measurement channels and four actuating channels can be used to collect data on temperatures, electric voltages, mass and energy flows and working times. Ten of the peripheral units will be dedicated to the building, one of the units will be dedicated to an outdoor testing facility and the remaining five units are for future expansion. Data will be stored on magnetic tape with analysis deferred to the Physics Department Computer or the Central Data Processing Computer.

\section{Status}

The building has just been completed and is now occupied. Instrumentation is in progress.

\section{Example Results}

Not yet available. 


\section{Comments}

This project is an important experiment for Switzerland because it will be the first effort to measure the energy and comfort performance of passive and hybrid strategies in the context of an office environment rather than a residental environment. It is of course true that the occupants of the building, being solar researchers, do not represent a completely unbiased, representative sample of office workers. Nonetheless, energy and comfort performance can be normalized to various occupant use scenarios. To this end, the dedication of the occupants provides the advantage of experimenting with various modes of use not possible in a conventional office building situation.

\section{$\underline{\text { References }}$}

Groupe de Recherche en Energie Solaire, "LESO: Le Laboratoire d'Energie Solaire", Department of Physics, Case Postale 1024, CH 1001 Lausanne, June 1980 


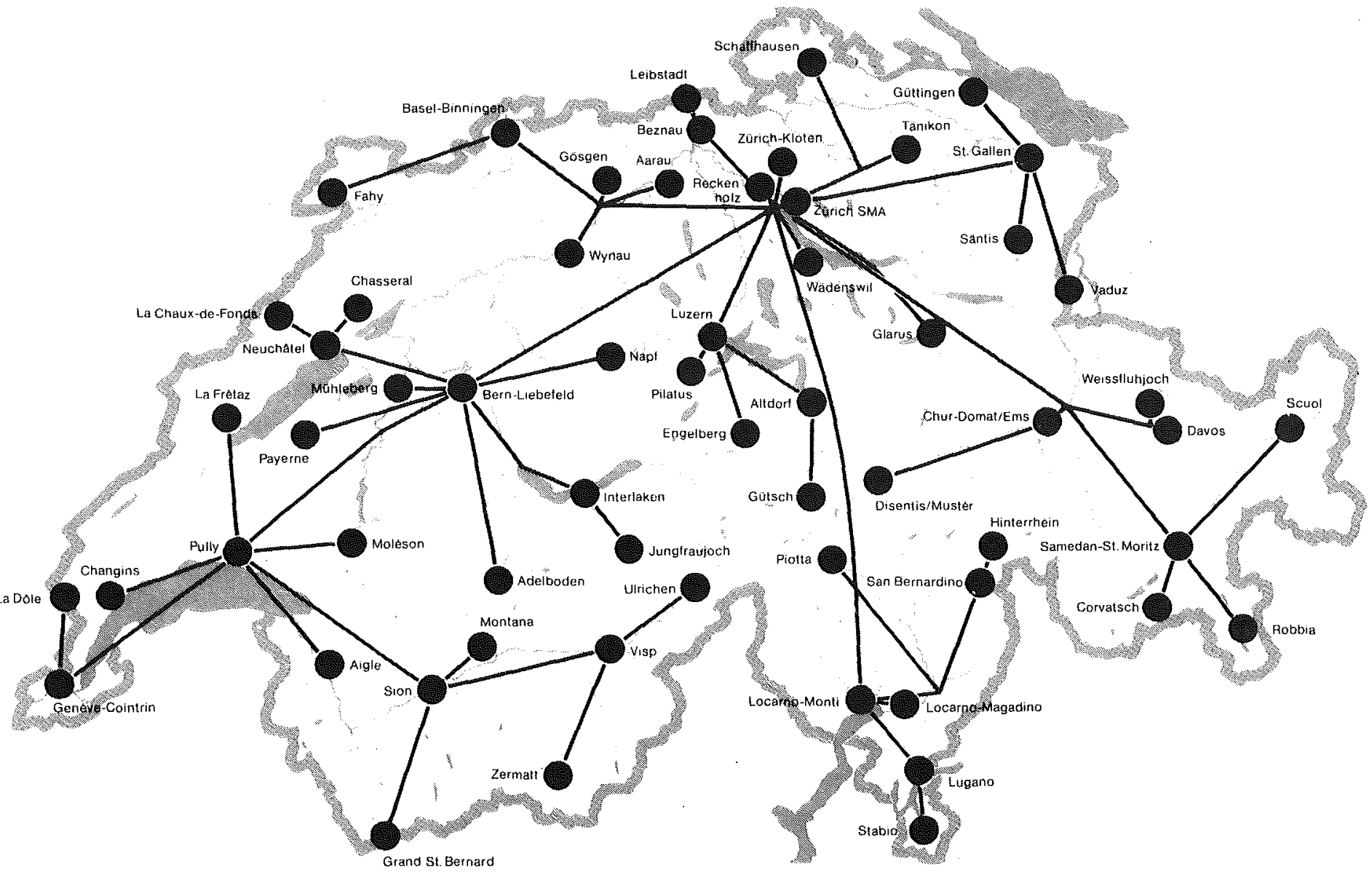

\subsection{AUTOMATED CLIMATE DATA COLLECTION NET}

BACKGROUND

In 1973 the SMA (Swiss Meteorological Institute) produced a study showing the necessity of a net of automated meteorological stations. The study convinced the government of the need and project development started in 1973. By 1978 a net of 20 stations were in operation providing data for weather prediction, agricultural planning, small aircraft routing, etc. Since its inception, the need for climate data for predicting building energy consumption has become apparent. For solar design, measured hours of sunshine and computed global and vertical south, east, west and north solar radiation are available for 60 locations through the Technical Meteorology Section of the SMA, headed by Dr. P. Valko. 


\section{Objectives}

- Build an automated network of meteorological stations which provides complete and precise data with a high rate of data transmission independent of qualified personnel at the site.

\section{Approach / Method}

50 ANETZ stations have been built jointly by the Swiss Meteorological Institute and the Agricultural Research Institute. Ten more stations are planned. Automatically collected data include: air pressure, air and ground temperatures at various depths (the latter at selected stations), humidity, wind direction and speed, precipitation, sunshine duration, illumination (lux), horizontal global radiation, evaporation (mm water evaporated from a $500 \mathrm{~mm}^{2}$ water surface per unit time), and incidence rate of lightning. In addition some visual observations can be added such as information on cloud types and cover. Ten of the stations are planned to also measure direct solar radiaton.

The whole system cost circa $\$ 2.5$ million. Annual operating costs amount to circa $\$ 225,000$.

All the measured data are transmitted to a central computer at ten minute intervals, then directly transmitted to the user institutions.

The main computer of the Swiss Meteorological Service in Zürich makes initial validation to assure that the data are within range, and transforms the data into the users format; access is provided to other users through the ETH-Z Central Computer. A second parallel computer in Locarno-Monti, provides a back-up to the Zürich system.

The title page shows the distribution of the stations. The stations' positions have been chosen in order to get a representative overview of the Swiss climate. 


\section{Status}

The ANETZ system has been in operation since 1978 when 20 stations were installed on a trial basis. In 1980 approximately 50 originally planned stations were completed. In the near future 63 stations will be in service.

\section{Example result}

ANETZ system results are continuous files of weather parameter values in metric units stored short term on on-line disks and long term off-1ine to the SMA computer.

\section{Comments}

With the implementation of ANETZ, Switzerland has the most dense meteorological measuring system in the world.

The several laboratory and university test cells and instrumented buildings with meteorological stations provide a useful complement to the system.

For simulating the energy performance of passive solar buildings it would be very useful if ANETZ collected direct normal solar radiation data thus permitting determination of direct and diffuse radiation.

\section{Publications}

SMA, "ADOC", Swiss Meteorological Institute, Krähbühlstrasse 55, 8044 Zürich, Switzerland 


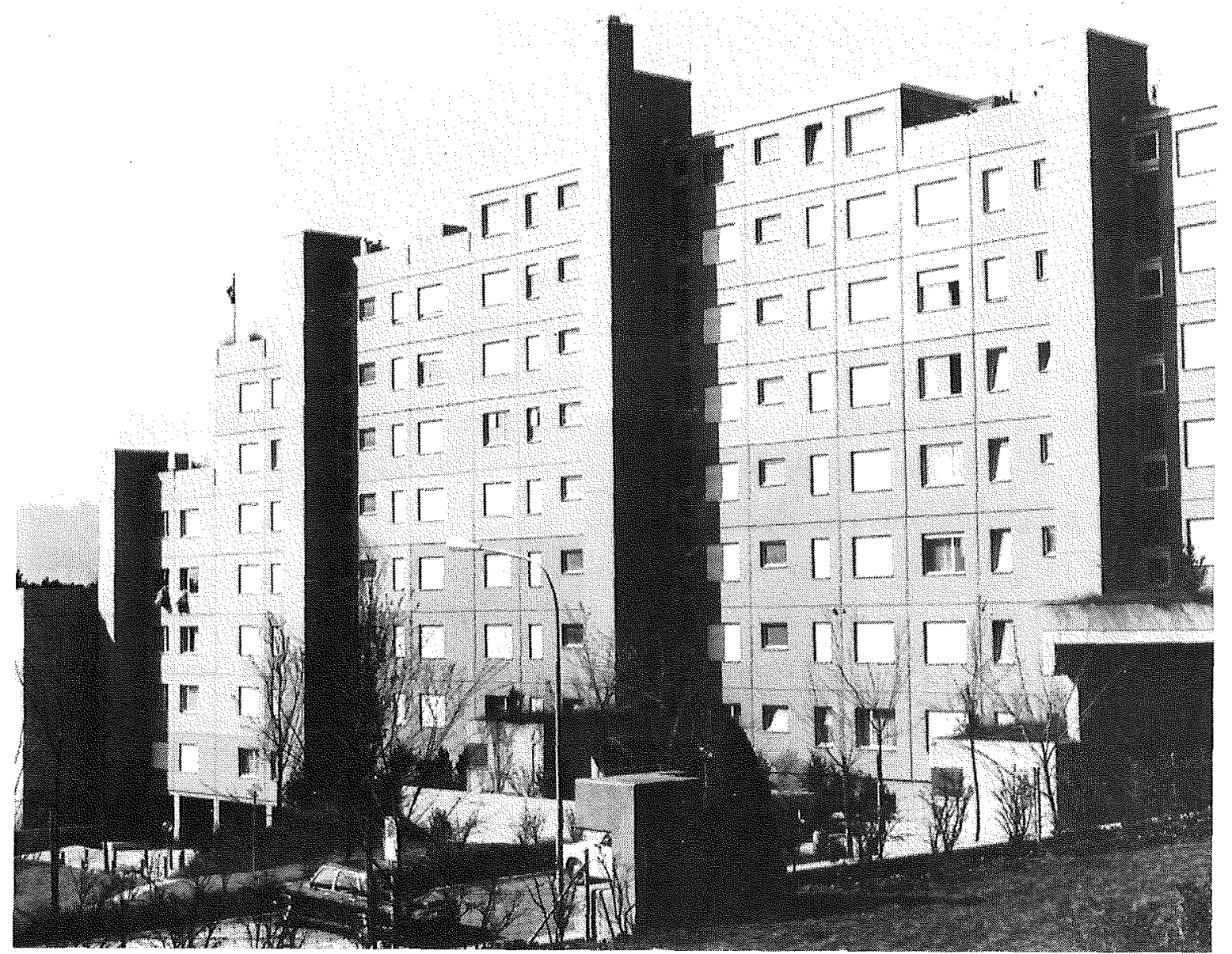

\subsection{OCCUPANT FACTOR / AIR CHANGE RATE DATA BASE}

BACKGROUND

This project is actually a continuing series of projects begun in 1975 by EMPA with Dr. P. Hartmann the principal contact. The goal of the research is to establish more precisely the rate of air change which actually occurs in occupied dwellings. The heat lost due to deliberate or inadvertent ventilation can equal the heat lost by transmission through a well insulated building envelope. When occupants partially open windows, the heat loss by infiltration overwhelms that lost by conduction. Yet in calculating a building's energy performance the number of air changes per hour is often only an "educated" guess. This project is directed at informing this best guess process. 


\section{Objectives}

- Measure how the air change rate varies as a function of occupant behavior (window and door openings) relative to climate, building, and apartment type, and location in the building.

- Record occupant behavior based on observation of a sample of buildings.

- Establish generalizable air change rates for comparable buildings based on observed behavior and the previously measured effects of such behaviors on air change rates.

- Develop statistical correlation functions relating occupant variables, building geometry variables, and climate variables to air change rates. (While the sample size is too small to provide an acceptable confidence level, it does provide an illustration of how such functions could be generated given a larger sample size).

\section{Approach}

The first objective, measuring air change rates as a function of various parameters, was accomplished by actual measurements of a sample of dwelling types. This sample included: two elevator apartment blocks with measurements taken in two two-room flats, one three-room flat, two fiveroom flats and one 5 1/2-room flat; three single family houses, one row house, one office in a five story building, and one two-room full scale test cell. Two measurement approaches were taken. First, a window and door schedule were compiled and a sample of these components was measured for insitu air tightness. This was accomplished using the conventional procedure of installing a plastic film over the component, pressurizing the space between the film and the component with a small blower, then measuring the pressure difference between the pressurized space and the ambient pressure for specified airstream volume flow rate from the blower. 
Such data provide an improvement in estimating airtightness versus the conventional approach of merely using crack length. The second, detailed approach was to evalutate the air change rate in various rooms or combinations of rooms in each dwelling using the conventional tracer gas decay measurement technique. $\mathrm{N}_{2} \mathrm{O}$ was used rather than $\mathrm{SF}_{6}$ which is commonly used in the U.S.

Plastic film

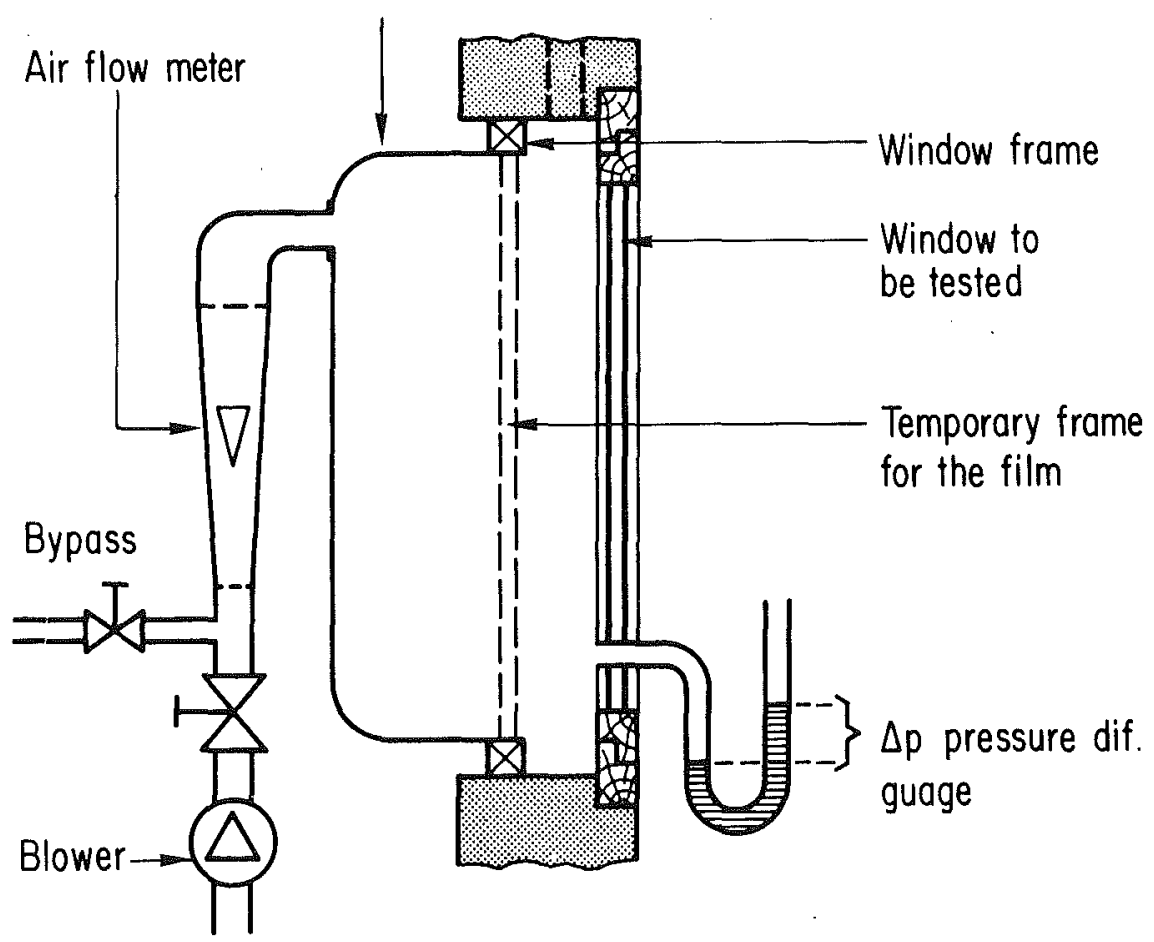

Fig. 37 Window Insitu Measurement 
The second objective, providing data on occupant behavior based on observation, has been conducted by observing and systematically recording window sash and rolladen * positions for a sample of apartments in a development in Volketswil for two days and in Zürich in the Limmatstrasse apartment block for one day. A more intensive study involved observations of two apartment buildings. During 65 days between October 1977 and ApriI 1978 window positions and rolladen positions were recorded at $1000 \mathrm{~h}$ and $1600 \mathrm{~h}$ for each of the 24 three-room and eight one-room apartments. For six days during this period observations were increased to half hour intervals. To estimate window positions when the rolladen is lowered, as at night, occupants were interviewed. An alternative to inverviews would have been to take infra-red photographs. Such photographs clearly indicate whether or not a window is open behind a closed rolladen.

The third objective, estimating air change rate is being pursued with a simple computer program which reads observation data on window position, assigns hourly infiltration rates based on the previous tracer gas experimentation with similar apartments, and calculates daily infiltration and resulting heating energy values.

The fourth objective, developing a set of correlation functions, involved a standard curve fitting procedure to generate values for the constants $A, B$ and $C$ in the following equation of physical parameters:

$$
n_{L}=\left[A+(B \cdot d T)+\left(C \cdot v^{2}\right)\right]
$$

where:

$$
\begin{aligned}
& \mathrm{n}_{\mathrm{L}}=\text { number of air changes per hour } \\
& \mathrm{dT}=\text { inside to outside temperature difference } \\
& \mathrm{v}=\text { wind speed in } \mathrm{m} / \mathrm{s} \text { at a reference height of } 10 \mathrm{~m} .
\end{aligned}
$$

* A rolladen is a horizontal slat blind in a track outside a window. It is raised or lowered from the inside without opening the window. When raised it rolls into a box built into the wall at the top of the window 
The frequency of a window being open, " $\mathrm{f}$ " is calculated according to equation (2).

$f=K\left(1-k_{1} \cdot d t-k_{2} \cdot v\right)$

where:

$\mathrm{K}=\mathrm{a}$ constant

$\mathrm{k}_{1}=\mathrm{a}$ user function correlated to temperature difference

$k_{2}=a$ user function correlated to wind velocity.

The window opening factor " $f$ " is then superimposed in equation (1).

$n_{L}=f(A+B x d T+C x v)$

\section{Status}

Step one, in-place measurement of building envelope components and tracer gas analysis of various window and door positions in a sample of apartments, has been completed and the documentation published in several sources. Step two, observing and recording occupant behaviors, was completed in 1981. Step 3, observations and tracer gas measurements was completed in the spring of 1981 for the apartment buildings near EMPA and a detached house in Maugwil. The computer program is operational. The final step of generating correlation coefficients for calculating air change rates is also in progress. Success is dependent on a larger sample size in the future in order that coefficients be more statistically reliable.

\section{Example results}

To illustrate the result obtained in step 1 where air change rates were measured in a sample of apartment types, the data for the five-room apartments are presented. The floor plan and window and door crack lengths are shown in the next Figure. 

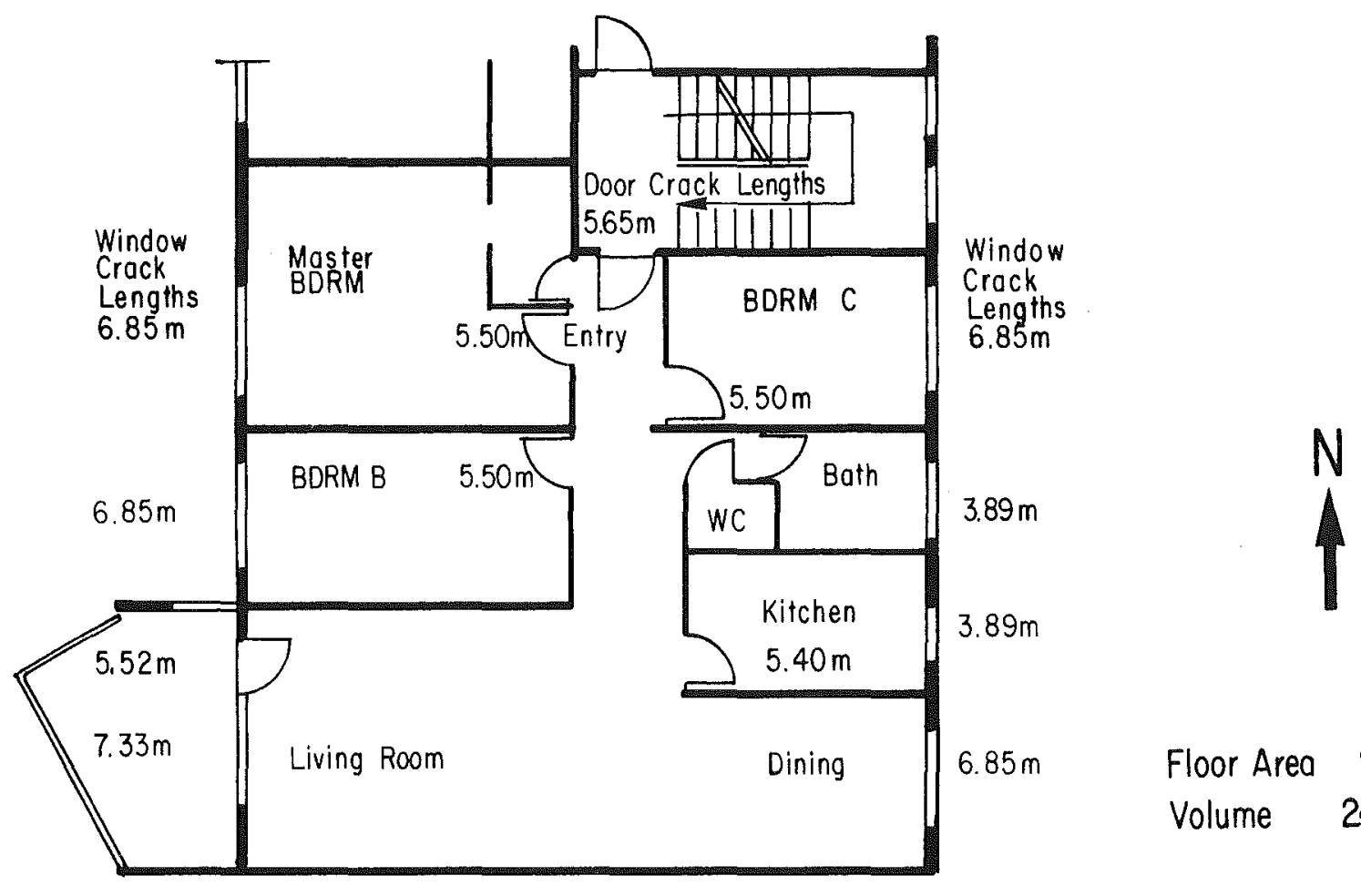

Fig.38 Apartment Plan

The number of air changes occuring in the apartment is strongly affected by the wind characteristics and window and rolladen position. Whether doors between rooms in the apartment are open or shut is also a lesser factor. The two curves of the tracer gas decay rate shown in figure 39 indicate how the air change rate of the living/dining rooms is affected by change in wind direction and velocity.
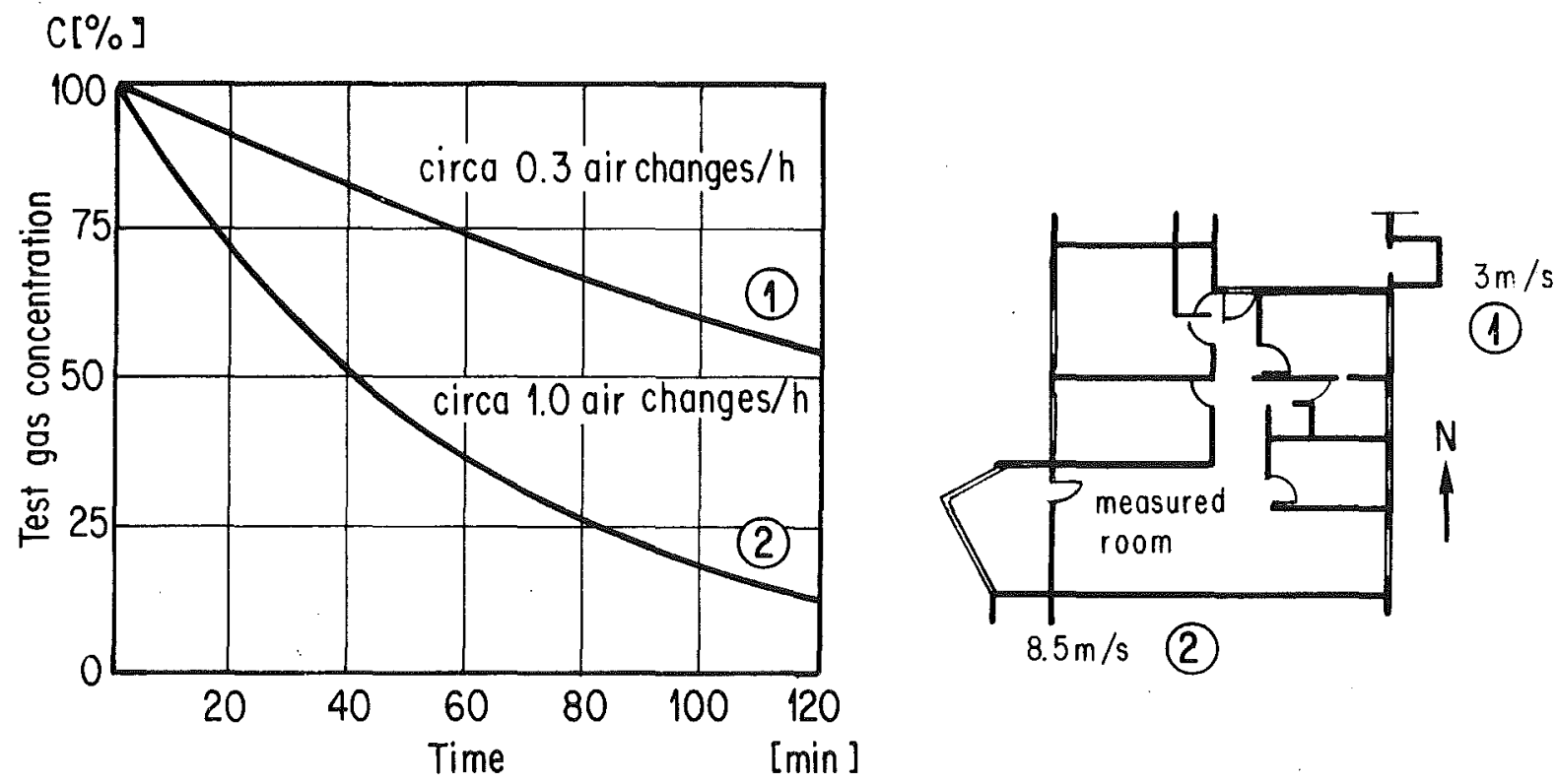

Fig.39 Air Change Rate Versus Wind Direction and Velocity 
Similarly, the window and roll blind position affect the number of air changes as shown in figure 40 . Even with the casement window only open $10 \mathrm{~cm}$ and the rolladen lowered the air change rate increases by an order of magnitude over the closed window. With the window in the $10 \mathrm{~cm}$ open position and the rolladen raised, the air change rate increases by one air change per hour. With the window completely open the air change rate increases by a factor of 60 from the shut window.

Tracer gas concentration

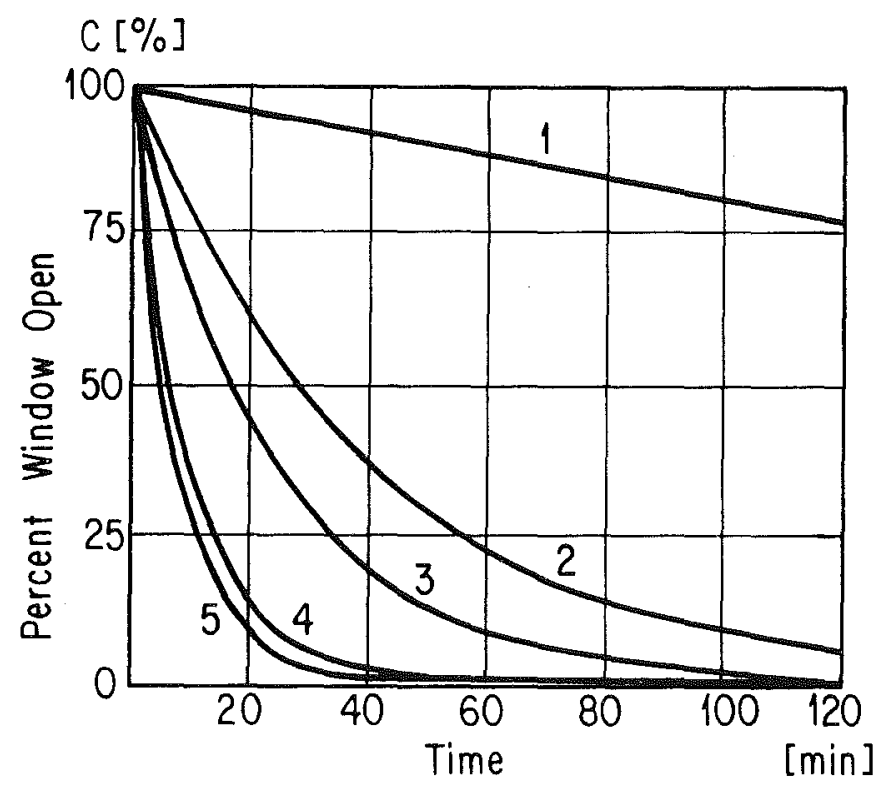

1) Window shut / Roll blinds raised

2) Window $10 \mathrm{~cm}$ open / Roll blinds shut

3) Window $10 \mathrm{~cm}$ open/ Roll blinds raised

4) Window opened to $45 \%$ Roll blinds raised

5) Window opened to $90 \%$ Roll blinds raised
Wind

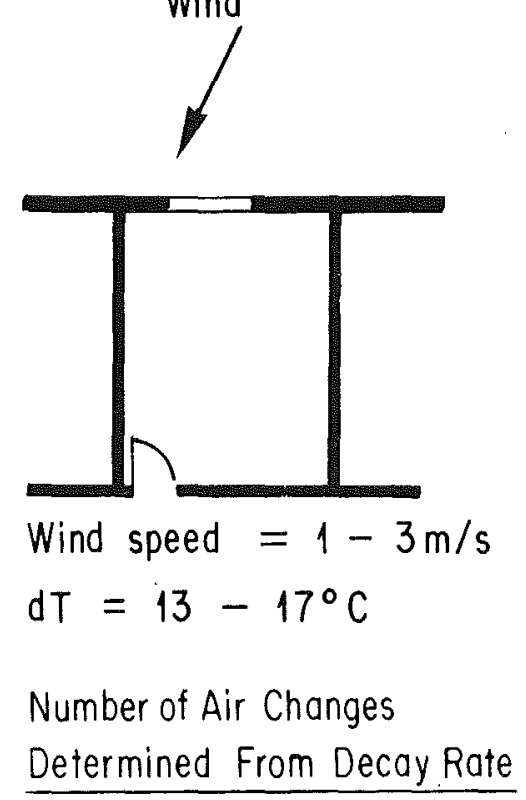

$0.15 \mathrm{~h}^{-1}$
$1.5 \mathrm{~h}^{-1}$
$2.5 \mathrm{~h}^{-1}$
$6.0 \mathrm{~h}^{-1}$
$9.0 \mathrm{~h}^{-1}$

Fig. 40 Tracer Gas Decay Rate Versus Window Opening

The effect of interior door positions on the air change rate of rooms given various window positions, is partially shown in the figure 41. From the various combinations it is apparent that door positions are less of a factor than wind speed or even a slight opening of a window. More measurements are needed, however, to quantify the moderating influence of closed doors given partially or fully open windows. 
FIG. 41 AIR CHANGES RELATIVE TO WIND AND WINDOW / DOOR POSITIONS

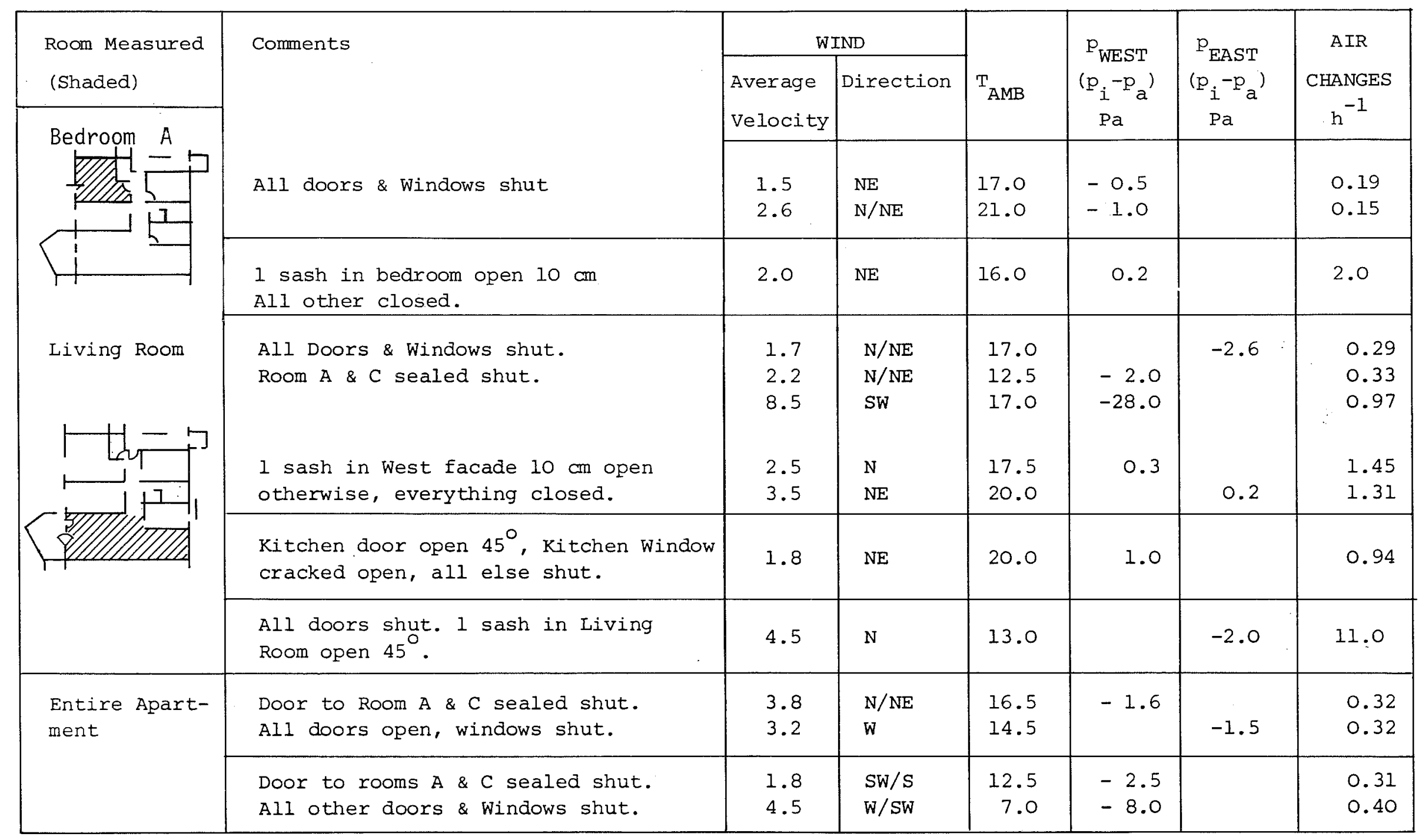


The second step, observation of occupant behavior relative to window opening, is currently in the data analysis phase. The pilot study provides an example, however. Figure 42 illustrates window and rolladen position for 22 apartments, all occupied. The data from $0600 \mathrm{~h}$ to $2000 \mathrm{~h}$ is statistically complied from analysis of photographs taken at 15 and 30 minutes intervals for a Wednesday and a Saturday in mid winter. The data for the period from midnight to $0600 \mathrm{~h}$ and from $2000 \mathrm{~h}$ to midnight are interview statistical data.

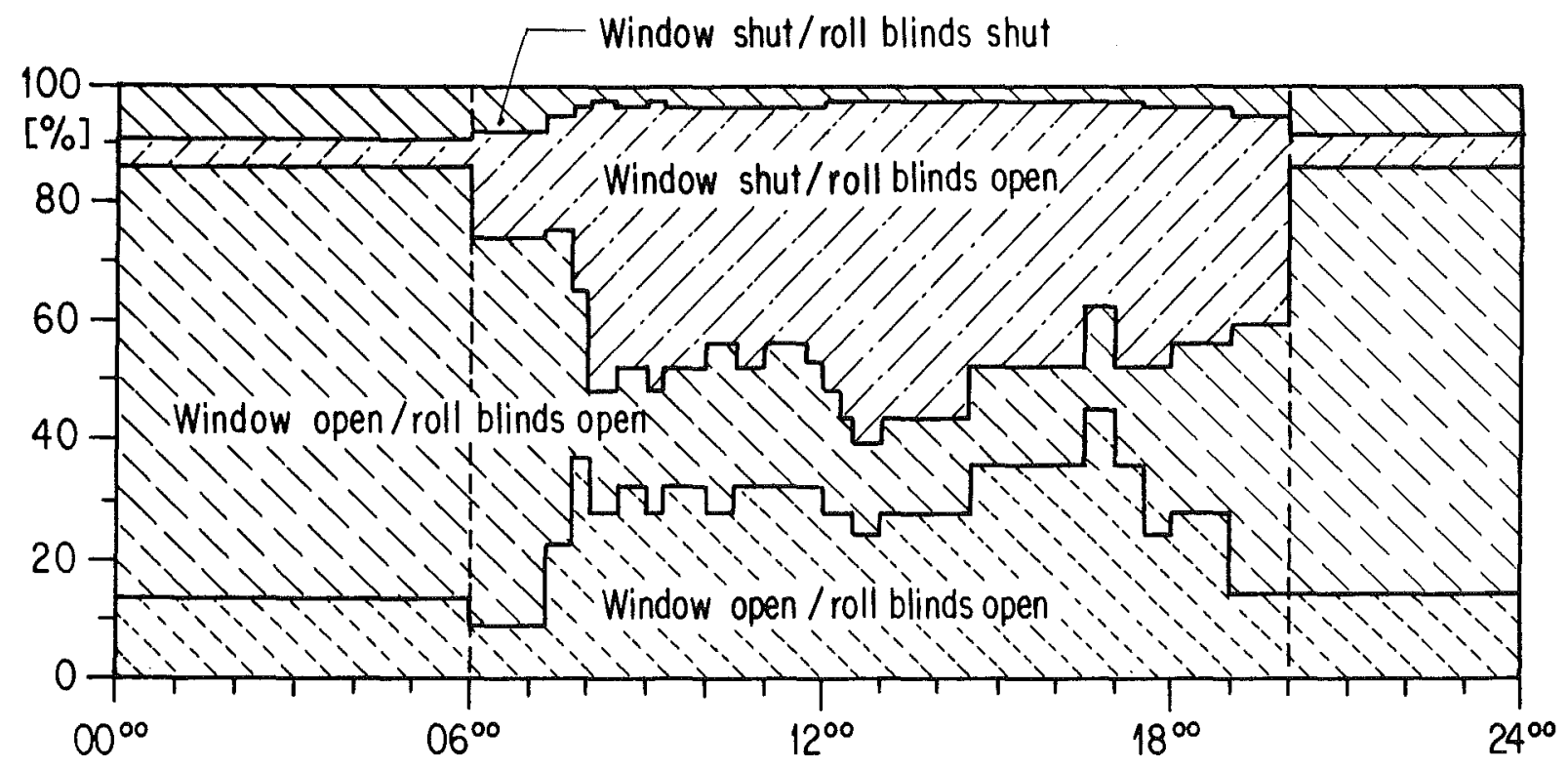

Bed Room

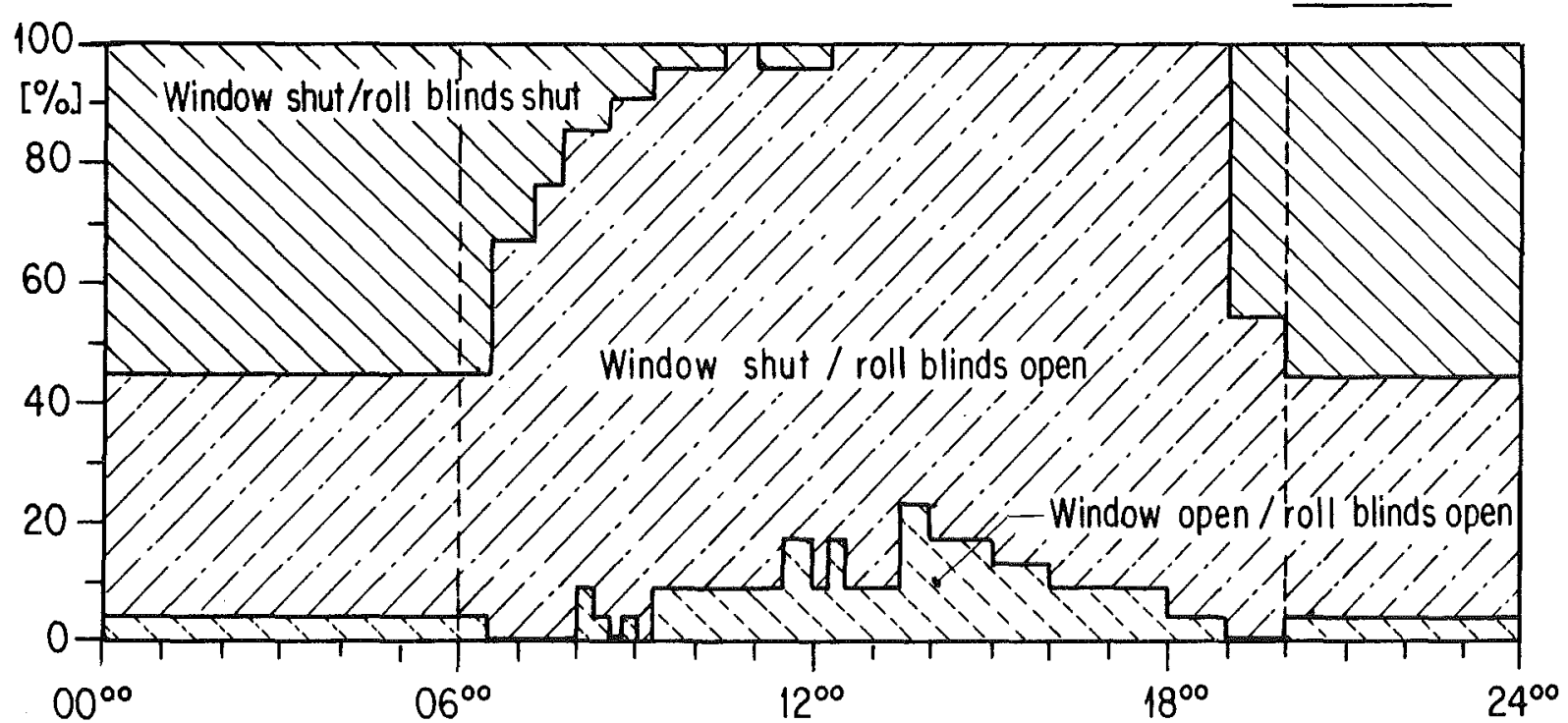

Living Room

Fig.42 Window and Roll blind Use Bosed on two Days of Observation and Occupant interviews 
Table 4 illustrates the calculated effect of occupant positioning of windows and roll blinds on air change rates and resulting make-up air heating requirements. The schedule of window and roll blinds positions is statistically determined for each day from observations of two low rise apartment blocks similar to those previously studied. Based on the measurement experience of the previous study, occupied room air change rates were assigned for various window and rolladen positions as follows:

\section{$\underline{\text { Configuration }}$} \\ Window shut/roll blinds down \\ Window shut/roll blinds up \\ Window open/roll blinds down \\ Window part open/roll blinds up \\ Window full open/roll blinds up
}

Factor multiplied by unoccupied room air change rate
X 0.6
X 1.0
X 7.0
$\mathrm{X} 10.0$
$\times 30.0$ 
TABLE 4 AIR CHANGE RATE AND RESULTING HEAT LOAD CALCULATED FROM TEMPERATURE, WIND SPEED, AND OCCUPANCY FACTORS

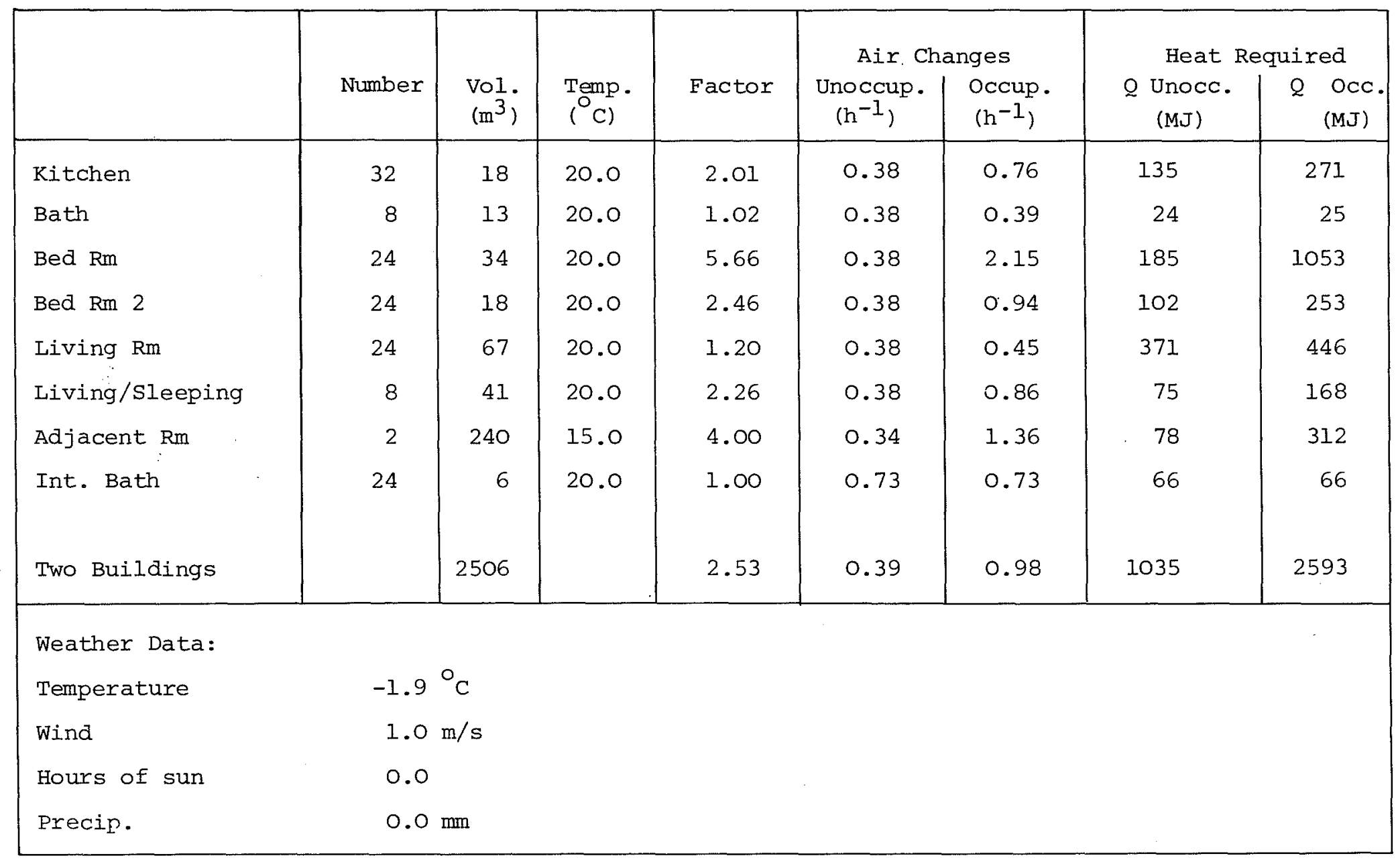




\section{Comments}

Because air change rates can represent such a large percentage of heating requirements it is imperative to have quantitative data on actual air change rates which occur in occupied buildings. With even partially opened windows the infiltration heating losses overwhelm transmission losses through the building walls and roof. Realistic analysis of expected energy savings from various retrofit or new design conservation strategies should recognize occupant behaviour factors if, in fact, the analyses are to be realistic. This project is valuable because it defines types of behaviors and quantifies their duration based on both observation with photographic documentation and interviews with the occupants. This information is then coupled with measured data from the tracer gas studies on how the defined behaviors alter the rate of air change in various types of dwellings. Such data will be helpful for a forthcoming building code decision whether mechanical ventilation systems should be mandatory for new residential buildings .

No one should infer from the results of these initial studies that sufficient data are now available to accurately correlate air change rates to occupant behavior. Two major areas of work need substantial amplification: First, the completed studies could only evaluate a sample of possible window and door positions and the resulating rate of tracer gas decay. Additional configurations which should be systematically studied include: windows open in bedrooms on opposite sides of an apartment and the effect on the air change rate of the remainder of the apartment rather than the bedrooms themselves; windows open in a given room and all doors open between rooms and the resulting air change rate of other rooms upwind and down wind from the room with the open window. One means of conducting such analysis would be to inject and measure tracer gas decay rates in all rooms simultaneously. In addition to determining air change rates, the air temperature profile for each room should be recorded. The influence of the thermal mass in a room on air temperature decay rates when a window is open needs documentation. 
A second category of needed research is statistical correlation of occupant descriptors and window and rolladen use. Example possible descriptors include age, education level, smokers or non-smokers, and number of working adults in the family. Similarly, statistical analysis of the correlations between wind direction and speed, temperature, and window rolladen position on air change rates are needed. As mentioned, an initial correlation is under developement, but a larger sample size is needed.

Once such research is completed, the implications of the data should be interpreted into example building designs which recongize occupant behavior and minimize the consequences of such behavior on heating demand.

\section{$\underline{\text { References }}$}

(1) EMPA-Report Nr. 34020: Luftwechselmessungen in nichtklimatisierten Räumen unter dem Einfluss von Konstruktions- und Klimaparametern; (Bericht 1) Dübendorf, Dec. 1977

(2) EMPA-Report Nr. 36620; Luftwechselmessungen in nichtklimatisierten Räumen unter dem Einfluss von Konstruktions-, Klima- und Benutzerparametern; (Bericht 2) Dübendorf, Mar.1978

(3) EMPA-Report Nr. 39400 b: Luftwechsel in Wohnbauten, FensterLüftungsverhalten der Bewohner zweier Mehrfamilienhäuser in $\mathrm{Ab}$ hängigkeit vom Aussenklima; (Bericht 3b) Dübendorf, April 1981

(4) EMPA-Report Nr. $39400 \mathrm{c}$ : Luftwechsel in Wohnbauten, LangzeitUntersuchungen betreffend Luftdurchlässigkeit und Luftwechsel eines Einfamilienhauses; (Bericht 3c) Dübendorf, April 1981

(5) Hartmann, P., Pfiffner, J., Bargetzi, S.: Luftwechselmessungen von ausgewählten Wohnbauten in der Schweiz, Klima- + Kälteingenieur, Heft 3, (Kurzfassung Bericht II) (Available in English) 1978 


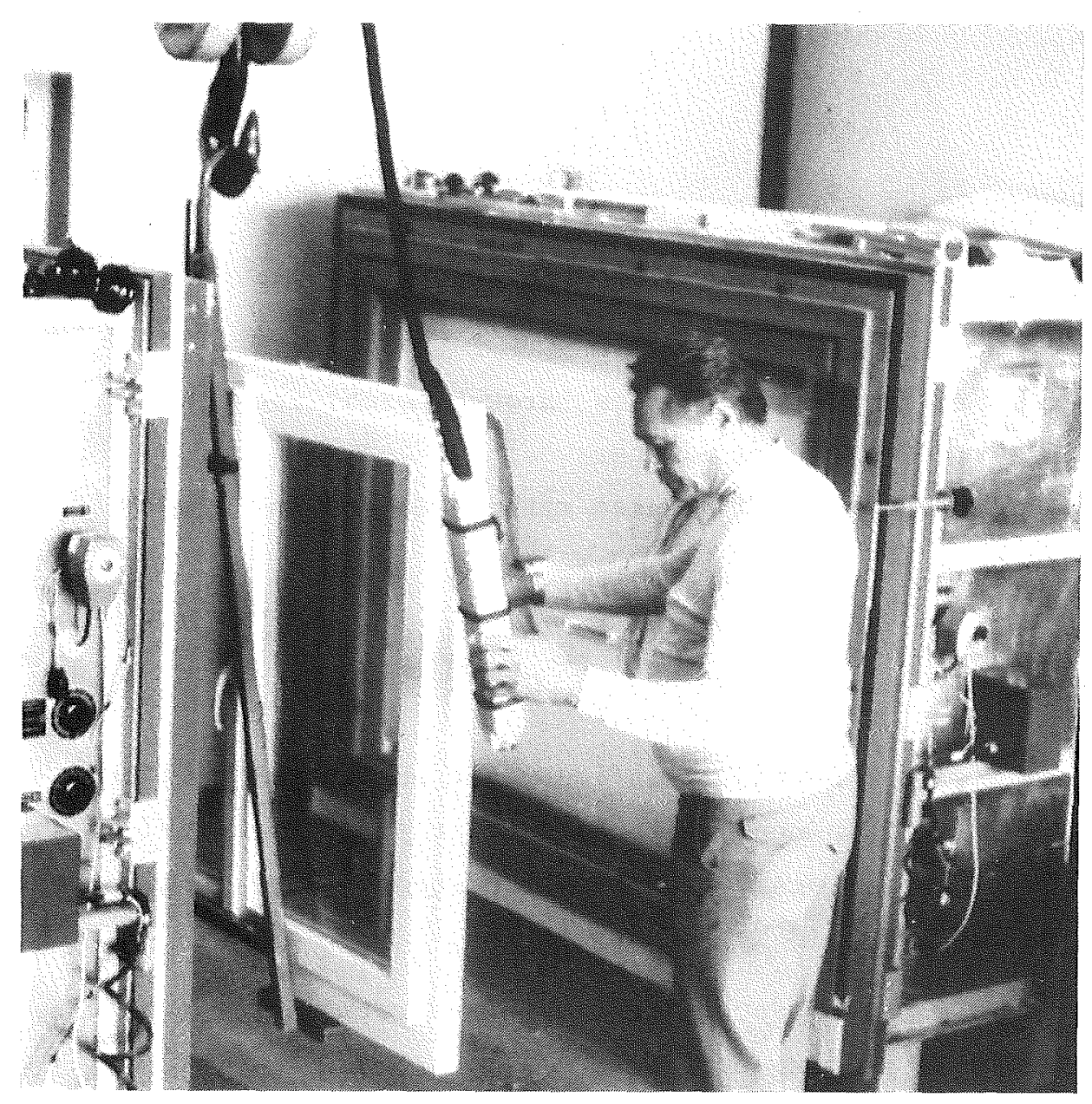

\subsection{IMPULSE PROGRAM: COMPONENT TESTING DATA BASE}

\section{BACKGROUND}

The Swiss government is sponsoring an extensive program to measure the performance of building components in conjunction with a training program for building design professionals involved in energy conservation retrofit projects. In the measurement program, building products used in energy conservation are tested. Replacement windows and insulation materials are two such example products. Testing is done at EMPA under Mr. R. Sagelsdorff, at EIR under Dr. P. Kesselring, at EPFL under Dr. C. Roulet, and at ZTL under Prof. F. Oezvegyi. 


\section{Objectives}

- Determine the important properties of each product relative to its intended use.

- Establish realistic comparative values through normalized testing.

- Exclude inappropriate use of products.

- Collect product information to be used within the Impulse Program's training courses.

\section{Approach / Method}

To ensure comprehensive results, it is important to test as many products as possible. As an inducement to have their products tested by the EMPA and the ETHL, manufacturers pay only 20 percent of the testing costs; the other 80 percent are paid by the government.

Manufacturers can use the product's test data and ratings for publicity upon completion of the testing program.

The products are divided into the following groups:

- Thermal insulation materials

- Insulating plaster

- Foam insulation

- Sandwich panels

- Vapor barriers

- Exterior insulation systems

- Insulating wallpapers and foils

- Windows

- Pipe insulation

- Solar collectors

- Thermostatically regulated radiator valves

- Heat pumps

Test samples of the products are randomly selected several times a year at the place of production during the three year measuring period. 
For systems or components of systems not subject to large variation in quality, only single tests are conducted.

\section{Status}

The Impulse program started in 1979 and runs through 1982. Some of the test results are now available. Windows are presently being tested. By 1982 all the test results should be available.

\section{Example Results}

Figure 43 shows a list of comparative values for Group 1:

Thermal insulation material. 


\begin{tabular}{|c|c|c|c|c|c|c|}
\hline$\theta$ & $\Omega$ & $\infty$ & 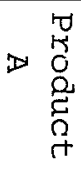 & \\
\hline & & & & Exterior Insulation-Plaster & & \multirow{5}{*}{ 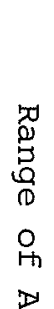 } \\
\hline & & & & Ext. Insulation Ventilated & & \\
\hline & & & & Interior Insulation & & \\
\hline & & & & Ground Ins, On Cold Side & & \\
\hline & & & & Ground Ins, On Warm Side & & \\
\hline & & - & - & Insulation Sep. from Roof & $\stackrel{-a}{2}$ & 帝 \\
\hline & & & & Insulating Roof System & 辛 & $\stackrel{\Omega}{\varrho}$ \\
\hline & & & - & Insulation between Rafters & D & . \\
\hline & & & & Insulation under Rafters & & \\
\hline - & - & & & Insulation under Membrane & 为 & \\
\hline & & & & Insulation above Membrane & 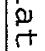 & \\
\hline - & & & - & Ventilated Roof & $D_{0}^{0}$ & \\
\hline & & & & Insulation in Side & 27 & \\
\hline - & & & & Floor on Ground, warm Side & & \\
\hline & & & & Floor on Crawl Space, Cold Side & 8 & \\
\hline - & & & & Floor on Crawl Space, Warm Side & & \\
\hline - & & & & Load bearing Insulation & & \\
\hline & & - & & Non-load bearing Insulation & 2 & \\
\hline & & & & $\begin{array}{l}\text { Insulation on Warm Side } \\
\text { (Wood-Beam Ceiling) }\end{array}$ & 恶: & \\
\hline & & - & - & $\begin{array}{l}\text { Insulation inside Construction } \\
\text { (Wood-Beam Ceiling) }\end{array}$ & & \\
\hline
\end{tabular}

\begin{tabular}{|c|c|c|c|c|c|c|}
\hline$\theta$ & $\Omega$ & $\infty$ & 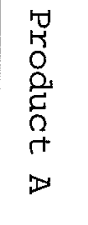 & \multicolumn{3}{|c|}{ 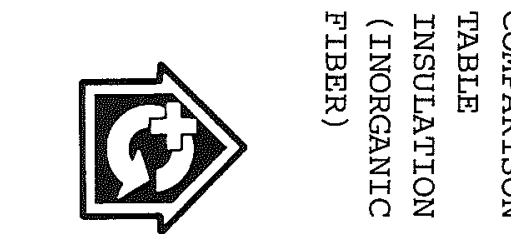 } \\
\hline $\begin{array}{l}\qquad \\
5 \\
0 \\
1+ \\
5 \\
\vdots \\
\text { in }\end{array}$ & $\begin{array}{c}\stackrel{b}{\infty} \\
0 \\
1+ \\
N\end{array}$ & $\begin{array}{l}N \\
1+ \\
1+ \\
\text { ir }\end{array}$ & $\begin{array}{l}\stackrel{N}{\triangle} \\
1+ \\
\omega \\
\dot{\sigma}\end{array}$ & 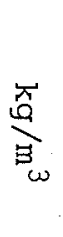 & $\begin{array}{l}\text { Required value } \\
\text { (SIA Norm 279) }\end{array}$ & 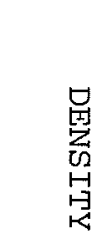 \\
\hline $\begin{array}{l}\omega \\
\omega \\
\stackrel{\omega}{\sigma} \\
\sigma\end{array}$ & $\begin{array}{l}\mapsto \\
\text { ज } \\
\infty\end{array}$ & $\stackrel{N}{\stackrel{N}{\oplus}}$ & $\begin{array}{l}\omega \\
\text { in } \\
\text { ir }\end{array}$ & 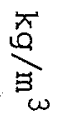 & Measured value & \\
\hline $\begin{array}{l}0 \\
\stackrel{\circ}{\circ} \\
\omega \\
\sigma\end{array}$ & $\begin{array}{l}\circ \\
\circ \\
\stackrel{\$}{\circ}\end{array}$ & $\begin{array}{l}\circ \\
0 \\
0 \\
0\end{array}$ & $\begin{array}{l}0 \\
0 \\
\stackrel{\rho}{0}\end{array}$ & \multirow{2}{*}{$\begin{array}{l}\sum \\
⿱ 亠 䒑 \\
\dot{X}\end{array}$} & Required & \multirow{2}{*}{ 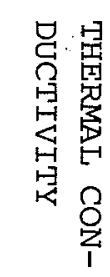 } \\
\hline $\begin{array}{l}0 \\
0 \\
\stackrel{D}{1}\end{array}$ & $\begin{array}{l}0 \\
0 \\
\stackrel{8}{0}\end{array}$ & $\begin{array}{l}0 \\
\dot{w} \\
\dot{J}\end{array}$ & $\begin{array}{l}0 \\
0 \\
\stackrel{0}{0}\end{array}$ & & Measured & \\
\hline i & $\dot{\omega}$ & $\stackrel{\leftrightarrow}{i}$ & \begin{tabular}{ll} 
& \multicolumn{1}{c}{} \\
$\infty$ & $\dot{0}$ \\
$\exists$ & 11
\end{tabular} & I & \multicolumn{2}{|c|}{ Moisture Transmission } \\
\hline$\stackrel{\circ}{\circ}$ & $\stackrel{0}{\omega}$ & 1 & i & $0^{\circ}$ & \multicolumn{2}{|c|}{$\begin{array}{l}\text { Expansion due to } \\
\text { Moisture }\end{array}$} \\
\hline $\begin{array}{l}\circ \\
\text { o } \\
\text { o }\end{array}$ & $\stackrel{\circ}{i}$ & I & 1 & $\stackrel{Z}{3}_{N}^{Z}$ & \multicolumn{2}{|c|}{ Compressive Strength } \\
\hline
\end{tabular}




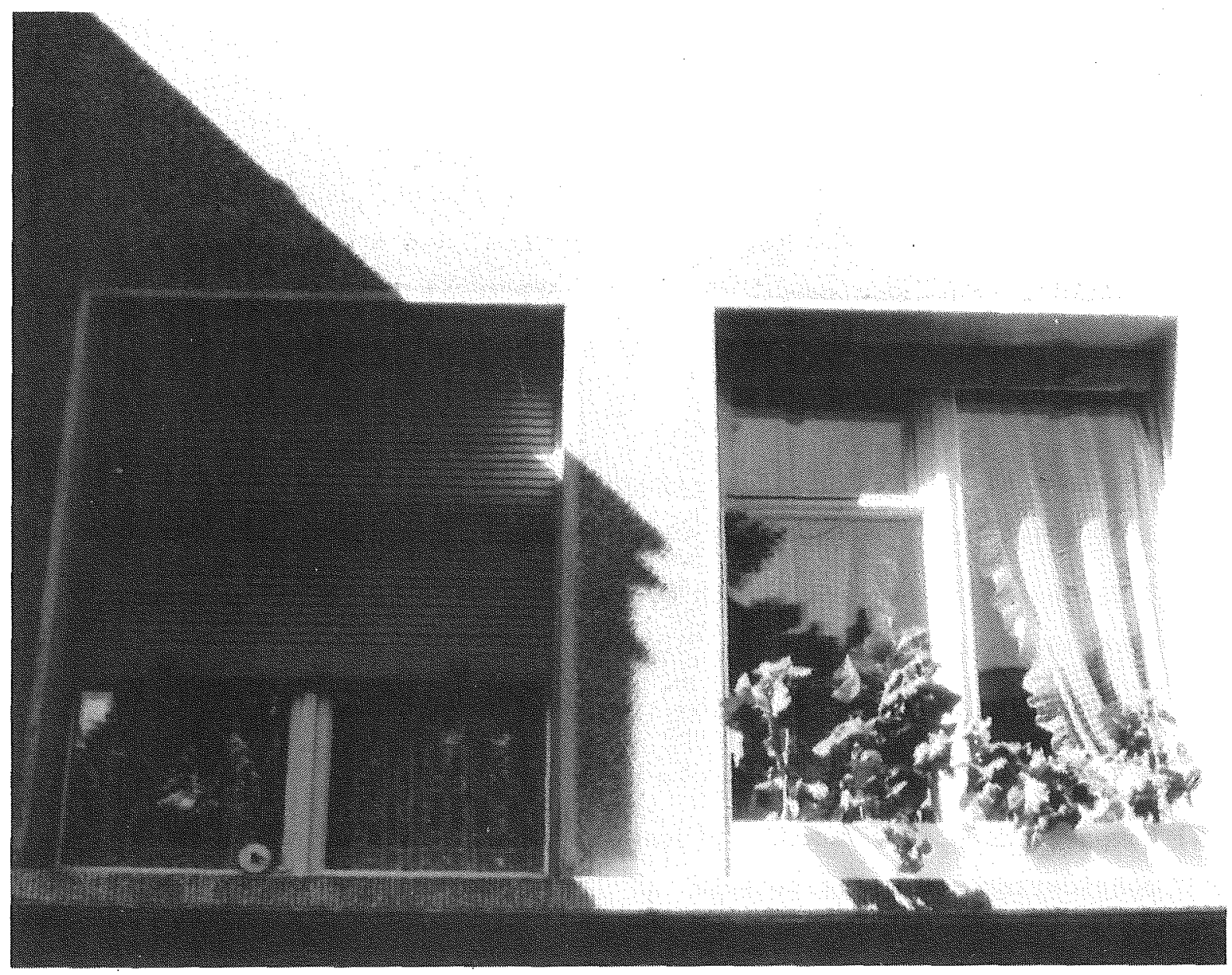

\subsection{A SIMPLIFIED METHOD FOR CALCULATING HEATING DEMAND}

\section{BACKGROUND}

A simplified calculation procedure for estimating residential energy demand has been developed by J. Gass of the EMPA. The procedure takes into account internal gains from people, solar gains, and the building mass. The method uses coefficients generated from computer runs for specified typical Swiss houses. Multifamily and single family building types are included and calculations are based upon a variety of different Swiss climatic conditions. 


\section{Ojectives}

- Develop a simple procedure for calculating the building energy requirements considering solar gain, building mass, and occupant factors.

- Calculate solar data needed by such a procedure from existing solar data.

\section{Approach}

Development of the calculation procedure required the following steps each of which will subsequently be explained.

1) Develop a simple means of estimating intensity of solar radiation from hours of sunlight.

2) Define representative building types for computer modeling

3) Define occupancy gain profiles.

4) Computer model the auxiliary heating requirements of the buildings considering the above factors.

5) From the computer analysis determine the percentage of usable solar/ internal heat.

1) Estimate solar radiation

A means of estimating solar intensity was quite important because in the Swiss climate solar gains can equal 10 to 50 percent of the magnitude of the heating load of a building. Switzerland now has a dense net of meteorological measurement stations but long term records of data exist for hours of sunlight only at sixteen stations and for global horizontal and diffuse solar radiation only at three stations. Building energy analysis requires data on radiation incident on vertical surfaces. A means was therefor needed to determine solar radiation incident on vertical surfaces from data on horizontal surface irradiation and hours of sunlight. The following method was used: 
For three stations data were assembled on global and diffuse radiation on the horizontal surface and on the duration of sunshine. A correlation function between the global radiation and the duration of sunshine was calculated for each month. Correlation functions for two stations in very different climates (south and north of the alps) were similar enough that one could assume they are valid for all regions in the country below $800 \mathrm{~m}$. At one station global radiation on vertical surfaces oriented to the four cardinal points was also measured. These measurements were used to determine the ratio between the diffuse radiation on the horizontal surface and on the different vertical surfaces. For lack of better information one has to accept that these ratios are generalizable until data from other stations become available. Results are shown in figure 44. The distribution of the direct radiation was then easily calculated with the help of the distribution ratios for the diffuse radiation. Monthly distribution ratios for the global radiation were then generated for the two other stations.

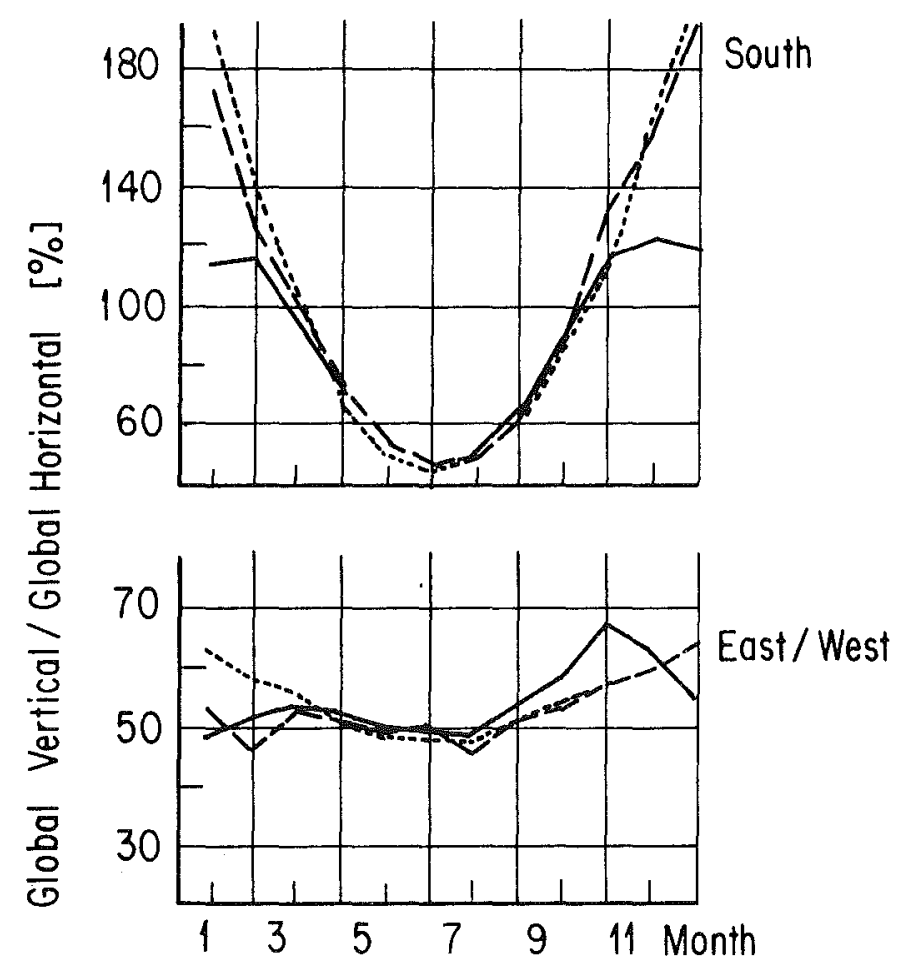

Monthly ratios between the global radiation on a vertical surface and on the horizontal surface (mean values over ten years)

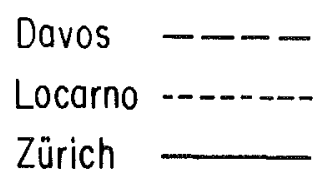

Fig. 44 Global Vertical to Horizontal Solar Ratios for Three Cities 
2) Define representative residential building types:

To generate building energy requirement data, four different

buildings, shown in figure 45, were defined which were deemed representive of a good cross-section of the Swiss stock of residential buildings.

12 - Story Tower Building (48 appartments)

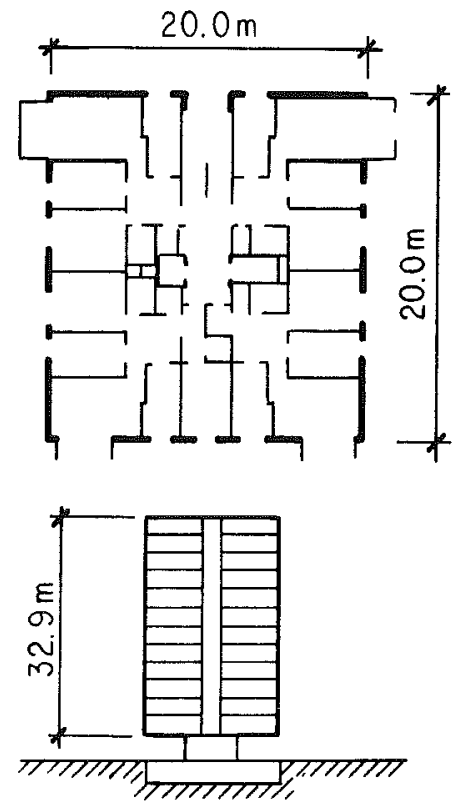

Multy Family House (6 appartments)
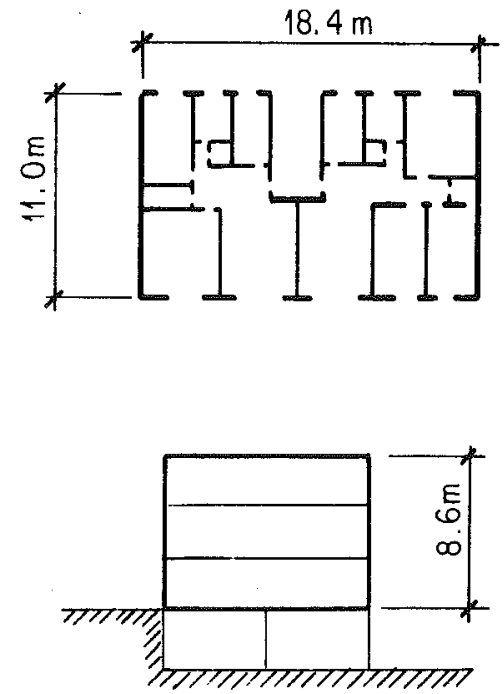

Multy Family House

(12 appartments)
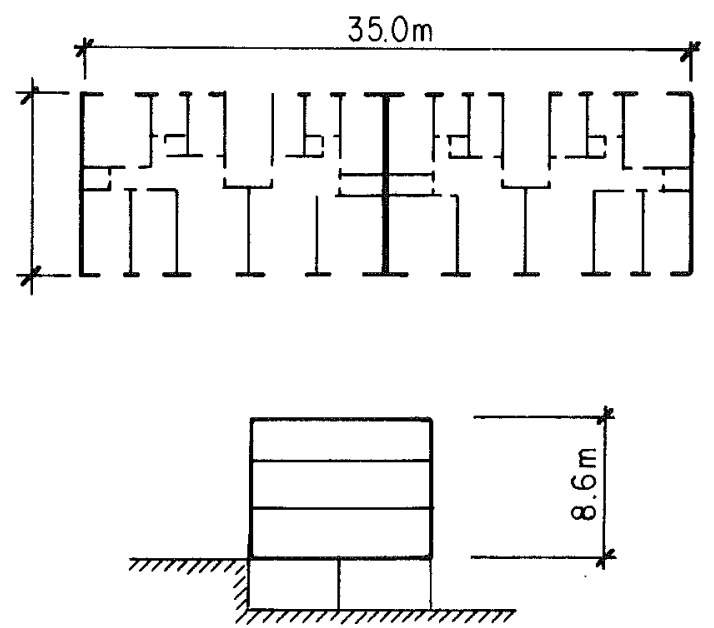

Single Family House
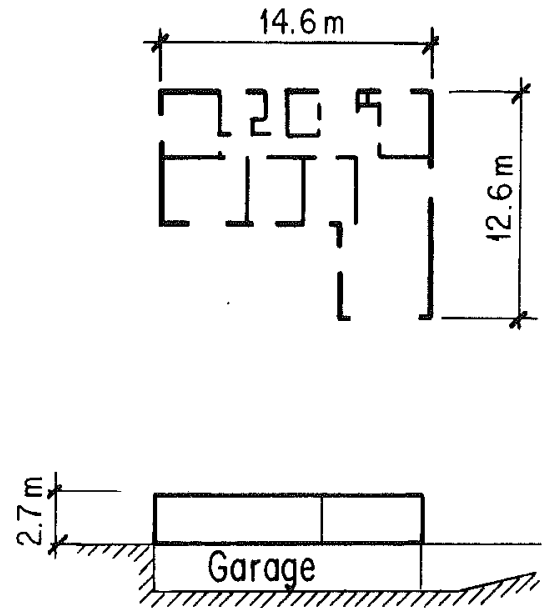

Fig.45 Representative Swiss Housing Type Designs 
3) Define occupancy heat gain:

The heat gain due to occupants was estimated at $10 \mathrm{MJ} /$ person day based on experience from other projects and the literature.

4) Mathmatically model building heating requirements:

Because free heat (solar and internal sources) was of special concern, monthly values were calculated for heat loss, the amount of free heat including its degree of utilization, and the net heat requirements. Combinations of the following variations were modeled: four building types, five climates, three insulation levels and three window areas. Five climates are characterized in table 5 by their degree days and vertical south solar radiation.

Table 5 Four Swiss Climates

$\begin{array}{lc}\text { Location } & \begin{array}{c}\text { degree-day } * \\ { }^{\circ} \mathrm{C} \text { day }\end{array} \\ \end{array}$

$\begin{array}{lrr}\text { Zürich } & 3641 & 917 \\ \text { Bern } & 3647 & 910 \\ \text { Genève } & 3035 & 979 \\ \text { Davos } & 5887 & 1059 \\ \text { Lugano } & 2596 & 1016\end{array}$

*) Heating degree days in Switzerland are calculated based on no heat being required above an ambient temperature of $12^{\circ} \mathrm{C}$. Below this point, the number of degrees is based on the difference between an assumed room temperature of $20^{\circ} \mathrm{C}$ and the average ambient temperature for the day.

5) Determine usable solar and internal gains:

Given the modeled building heating requirements for the four building types, a factor $\beta$ was determined for relating the free heat to the total building heat loss. The heating requirement can be expressed with the following equation. 


$$
Q_{\text {net }}=Q_{\text {loss }}(1-\beta)
$$

This term $\beta$ contains the influence of solar radiation and the normalized user influence. It is dependent on the climate and on the building type.

\section{Status}

The simplified calculation method has now been completed. As more measured data from instrumented buildings become available, the calculation procedure will be further tested for its validity and the coefficients further refined.

\section{Results}

Analysis of the computer data showed a strong dependency between heating energy, and the volume of the building and its insulation level. A parameter containing both insulation level and volume was therefor determined. The so called G-factor is the specific heat loss per unit volume and temperature difference. It is calculated as follows:

$$
G=\Sigma_{i}\left(A_{i} \cdot U_{i} / V\right)+0.34 \cdot n \quad W / m^{3} K
$$

Where: $A=$ building envelope area

$\mathrm{U}=$ building envelope average insulation value $(\mathrm{W} / \mathrm{m} \mathrm{K})$

$\mathrm{V}=$ building volume

$\mathrm{n}=$ number of air changes per hour

$i$ = subscript for each building envelope material.

The calculated values for $\beta$ are shown in figure 46 for the climate of Zürich, for all cases with medium window size (33\% of the south facade and $16 \%$ of the other facades. All the calculated points fall within a band of $\pm 2 \%$. For other climates the mean curve shifts downwards as degree days increase as seen in figure 47. 
Fig. 46 Percentage of the supply of usable free heat loss as a function of the specific heat loss per unit volume in the climate of Zürich

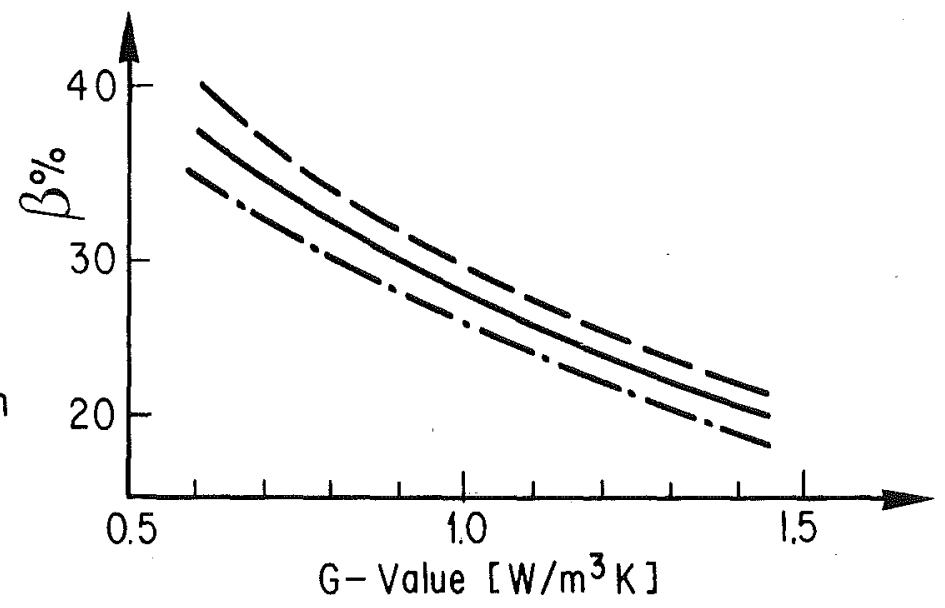

Fig. 47 Percentage of the supply of usable free heat of the total heat of loss in four different climates

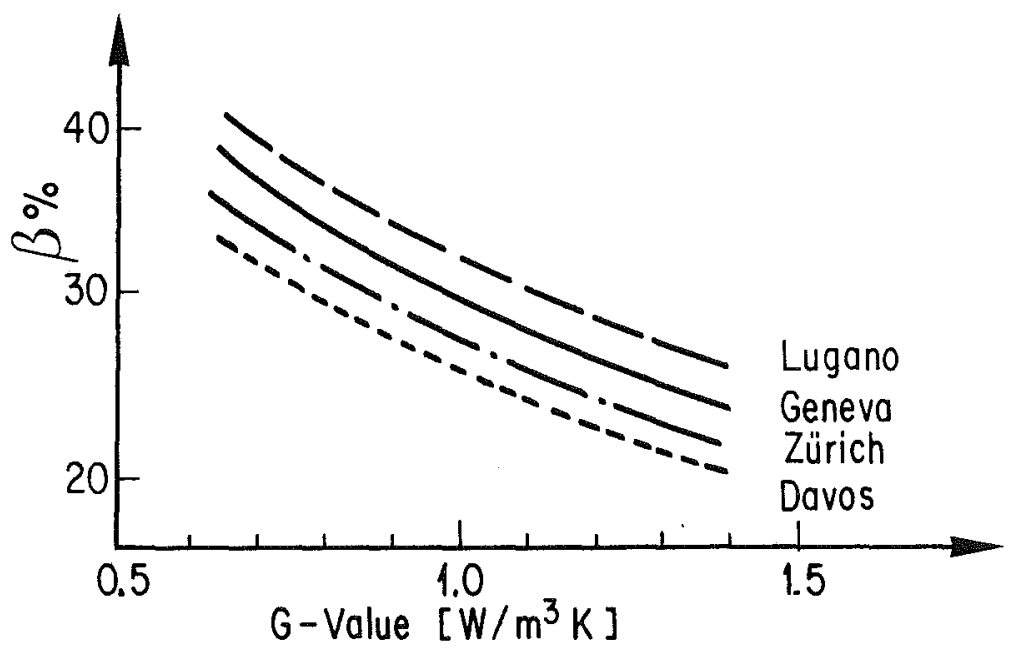

In using the simplified calculation method the following should be noted:

- The method only applies to heating (not usable for air conditioning)

- Heat gains reduce these losses by a factor (1- $\beta)$, which can be determined according to the G-value of the building and the climate.

- An increase from the assumed 35 percent window area for the south facade to 45 percent raises the term $\beta$ by two percent. 


\section{Comments}

Simple calculation methods for determining heat loads of passive solar buildings are needed in Switzerland. Present calculation procedured are insensitive to the effects of internal thermal mass and internal heat generation above or below some unclearly establishment values.

This calculation method is a valuable step in the direction of establishing such a method. The coefficients are based on a few typical example house types, however, and a statistical data base is needed for the performance of houses deliberately designed to take advantage of mass and internal gains.

\section{Publications}

Gass, J., S

Gass, J. "Simplified Calculation Method for Residential Energy Requirements", Proceedings of the International Energy Agency Conference, Berlin, West Germany, 1981. 
The preceeding selection of research projects provides an indication of Swiss research priorities. In this closing section these directions and areas of concentration will be examined in the context of an organizing research framework. By locating research projects in a framework then examining the framework it is possible to determine the breadth and depth of research by subject, type of research, and type of application. Profiling a country's research program helps identify important linkages among projects within the country, possible linkages to project areas in other countries and by virtue of the gaps, important subject areas for future research.
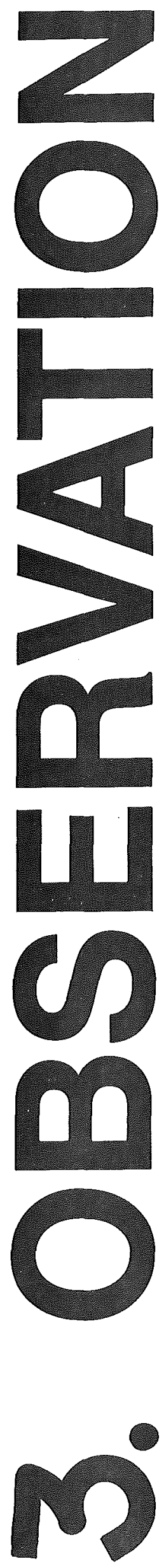
The research projects reviewed in the previous section were grouped by characterization of research activity, e.g. mathematical simulation, instrumented buildings, etc. In this section these groupings will be placed in the context of a larger and more detailed framework, diagrammed in figure 48 . The above mentioned research activities can be more precisely defined by application types, e.g. residential, institutional, mixed, etc. The resulting table of projects can be filled in for any given individual subject area of a given category of research. The categories are here defined as component research, systems research, and support research.

An inventory of Swiss building energy research using this framework is currently in progress. The ongoing or completed Swiss research projects are being entered in the framework. In an overlay framework, projects in other countries are being identified. Where gaps occur in the Swiss framework the other countries overlay can then be examined to see if Switzerland can profit from work done elsewhere. Similarly, redundancies between Swiss and other country research subjects indicate opportunities for each country to share results with the other. Finally, subject areas which have no project entries will be examined to determine if important opportunities to conserve energy are not currently being explored and warrant a shift in research efforts.

Based on the work completed to date on this effort, general observations will be presented in this closing section on the present priorities and possible future directions for energy conservation research. Comments will first be presented on subject areas within three categories: component research, systems research and support research. Comments will then be made on activities relative to type of research approach, and finally on different applications. 
Building Envelope Research

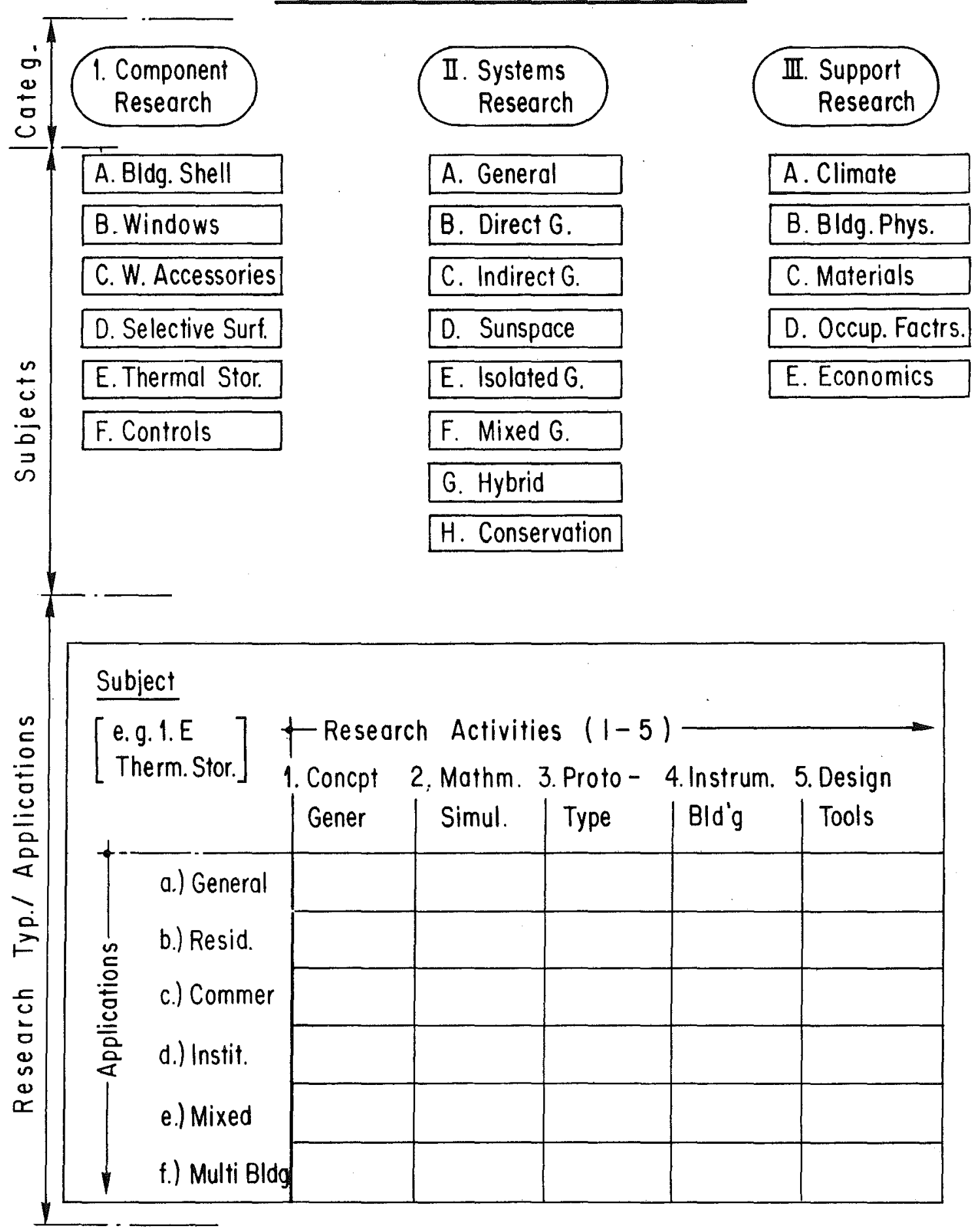

Fig. 48 A research Framework 


\section{RESEARCH CATEGORIES}

\section{Component Research}

Much research has been completed in various aspects of the building shell. Component testing and coursework preparation was completed for the Impulse Program on such elements as insulation systems, window types, and exterior surfaces. Work has been undertaken on the subject of selective surfaces including both simulation and instrumented prototype test cell applications. A start has been made in the areas of window accessories, controls, and thermal storage, primarily at the EPFL.

Suggested future work in component research should include research on the energy implications of architectural form relative to heating and to a lesser extent air conditioning, as well as lighting. The most recent examples of modern commercial and institutional architecture embody design and programmatic concepts which require extensive artificial illumination and air conditioning in spite of Switzerland's moderate summer climate. Preconceived or preordained geometric forms for various building types should be rigorously scrutinized for their energy implications and alternative building forms investigated.

More window research is needed to simulate and measure the energy implications of various window accessories and operation scenarios. The Solar Trap project is a good example of such research, but similar studies are needed for various passive solar window systems, such as selected moveable insulation components. Similarly, as new window accessories and new window glazing systems become available, it is essential to re-examine preconceptions of optimal window area for given climates. This is likewise true as the capability of sizing thermal mass relative to window area becomes more refined. The intense overheating of the Maugwil test cabins and even the Solar Trap test cell indicate the importance of the balance between glass and mass in a passive solar design. 


\section{System Research}

Most research on direct, indirect, sunspace and isolated gain passive solar systems has been pursued by the EPFL. Their work includes developing a simulation model, collecting data from test cells, and instrumenting occupied houses. EMPA has also pursued various passive solar projects including computer parametric studies of greenhouses and limited test cell research. Conservation research has not been as regionally concentrated as passive solar research. Conservation research is ongoing at EMPA, EIR, EPFL and the University of Geneva. EMPA and ETHZ are foci for the subject of air infiltration and EIR is a focus for active solar systems and heat pump augmented combined systems.

A likely and useful future direction in system research would be diversification of the above mentioned geographic and institutional research subject concentrations. While it may not be affordable to have centers of expertise on all subjects in all regions of the country, some dispersion of research involvement is important because locally pursued research is more likely to become applied locally than is the case with research conducted in a different part of the country. This is expecially true given the language and culture differences within the country. 
Specific systems research subjects which should be pursued include limited additional test cell measurement, instrumented building measurement of direct gain systems, attached greenhouses, and hybrid systems incorporating new products as they become available (e.g. IR selective multiple glazing, IR reflective multiple layer foil roll shades, and latent heat storage elements). Computer simulation work should continue parallel to mesurement experiments to examine the sensitivity of various aspects of a design and it's applicability in different climate zones.

Research on mass walls may be of a lower priority than other passive systems because of the lack of sun in much of the country. Mass walls suffer the inherent disadvantage that the absorbing surface, (which reaches the highest temperature) is immediately behind the glazing, which is the poorest insulator of the building shell and realizes the greatest losses, particularly at night. In a climate where solar radiation is a very precious commodity, such reradiation losses are particularly disconcerting. A modest research effort would be valuable to determine the extent that indirect gain mass wall system performance is enhanced when complimented with a movable insulation system to sharply reduce night losses. Mass walls can provide an important alternative solution to architectural problems. One example is the problem of designing a building for a north-facing mountain slope with a panoramic vista to the north and no view to the south. In such a situation, a mass wall comprising the majority of the south facade would be a valuable counter to the energy expensive windows capturing the north view. Critical would be, of course, the extent the slope curtails the number of hours of sunlight per day.

The subject of attached greenhouses mentioned above is particularly important because of the widespread interest among architects and their clients. The minuscule amount of available information on sunspace design in the Swiss climate coupled with the amount of sunspace building activity make this an urgent research issue. Research questions include the energy benefit of various configurations, thermal storage systems, moveable insulation systems, and air circulation systems between the dwelling and the sunspace. 
Isolated gain or thermosiphon passive solar space heating systems are rare in Switzerland. Little if any research has been conducted on the subject. In a climate with extensive periods of only diffuse solar radiation, effective system performance requires careful, informed design. Data and guidelines are lacking. A measurement project of an isolated gain system would be useful and several houses have been built using this principle.

A variant of an isolated gain system, though very much an active system, is the active facade system being investigated at EIR. In this system a serpentine of tubing is embeded just beneath the exterior of a concrete wall. A heat pump chilled fluid circulating through the tubing extracts heat from the sun-warmed surface of the concrete wall. The wall is heavily insulated from the building interior and thus in principle performs like an unglazed low-temperature isolated collector.

This raises the issue of mixed systems combined to take advantage of different solar collection situations (e.g. situations of weather, orientation or occupant needs). To date much of Swiss research has been concentrated on single systems considered individually. Research on passive systems acting interdependently is needed.

On the final systems research subject, conservation, it might seem that little further research is needed given the ubiquituous insulation retrofit activity evident by the scaffolding and facades partially clad in brightly colored exterior insulation. Work should be done, however, on developing concepts which integrate conservation strategies with occupant behavior. An obvious example situation is the custom of opening bedroom windows to air out the bedding and the room, sometimes for several hours during the coldest winter days. 
Conservation strategies which recognize this cultural phenomenon should be explored. One possible design which might be analyzed would be to design bedrooms such that they are easily and effectively isolated from the other living areas, that the construction is light (though heavily insulated to dampen sound transmission) rather than massive to minimize the amount of stored heat lost during the airing period, and that the heating system is automatically shut off when the windows are opened.

\section{Support Research}

Swiss work in the support research subject area of climate measurement is extensive. A major investment has been made in the ANETZ system, and in the Swiss Meteorological Institute.

Building physics is similarly an intensively researched subject area with substantial continuing research at the EMPA, ETHZ, EPFL, and to a lesser extent at the University of Geneva. Materials research is primarily industry sponsored rather than publicly supported. Many of the tests run at the EMPA, for example, are privately sponsored contracts. Occupant factors research in Switzerland has been both original and fruitful in the past. The work on the influence on window opening on air change rates demonstrates the importance of this subject area. Life cycle costing acquires a different perspective in Switzerland relative to the U.S. given the Swiss construction and investment philosophy of longevity. In this situation, amortization of invested principal is less hurried than is the case in the U.S. 
Future research is particularly needed in the occupant factors area. This type of research is important because of the magnitude of energy savings possible on a national level by influencing occupant behavior and by advancing design concepts which work with, rather than suffer from the behavior of occupants. The many closed roll blinds and shutters which can be seen on houses on sunny cold winter days illustrate the need to consider occupant needs in designing passive solar architecture. Low energy dwellings are likely to be even more sensitive than convetional houses to occupant influences, either positively or adversely affecting the energy balance of the building envelope.

In the climate subject area it would be valuable to collect diffuse and direct normal solar radiation at selected ANETZ stations. As hourly computer simulation models become incleasingly used, the lack of such data on a local level will become a major drawback.

A building physics research topic of particular concern is the issue of moisture transport through the building envelope. Another largely unknown area is that of the basic convection mechanisms in the dynamic interior environment of a sunspace.

Finally, in the subject area of materials research, guidelines are critically needed regarding materials properties and behavior in various possible passive solar applications. To a large extent, much of the work done in the U.S. can be used as base data. Materials common in Swiss construction but uncommon in U.S. construction necessitate testing. An example materials-related issue is the use of woodframing members in the construction of site-built solar air collectors.

Experience in the U.S. indicates wood so used is subject to severe long term degredation. The material performance of wood frame air collectors in Switzerland is unknown. 


\section{RESEARCH ACTIVITIES}

Research subject areas shown in figure 48 can be further classified by types of "Research Activities", namely: Concept generation, mathematical simulation, prototype development, instrumentation of buildings, and design tools.

Component concept generation in Switzerland is primarily privately funded by industry. An example project is the Solar Trap. Concept generation is also evident in architectural design, particularly regarding sunspace configurations. Example built concepts include moveable roof glazing to convert an interior sunspace into an open atrium, various means of providing thermal storage, and different summer shading systems for windows and sunspaces.

Development of simulation capabilities has been well supported with the creation of the PASIM passive solar network model at EPFL, validation of DOE 2 at EMPA, development of a radiation model at EMPA, and the development of several simplified calculation procedures which take into account the usability of solar and internal gains as a function of several building parameters.

Prototype testing (test cell measurement) has also been done at EPFL and EMPA. This work has been useful in gaining confidence in the validity of imported simulation models.

The Chaumiere apartment block in Lausanne, the Limmatstrasse apartment block in Zürich, and the single family house in Maugwil are the three most important examples of intensely instrumented Swiss buildings. The density of measurements in each of these examples is providing an excellent data base for examining in detail questions regarding building energy performance. The five solar houses measured by EPFL are also useful in refining the technique of collecting data from occupied passive Solar houses. 
Finally, regarding design tool development and design data generation, the principal activity has been in the development of course material for the Impulse Program, and the development of guidelines by the Swiss Society of Engineers and Architects (SIA). A number of architecture and engineering offices are developing their own calculation and design tools. Methods developed at Los Alamos are becoming popular, though there is a persistant caution in accepting correlation methods unproved in Switzerland's specific climates.

Future research support would be valuable in the form of grants to designers to generate new energy conservation building concepts, to take the resulting ideas through the level of construction detailing and prototypical application designs, and to perform detailed calculations of the energy performance. The details, physical principles, and energy performance could be published as a handbook.

Future support is needed in simulation, not so much to develop additional models, but to develop user-friendly input routines to the already existing models so that their use becomes possible for people other than the program authors. While PASSIM, DOE 2, DEROB, and the Frank models all are operational in Switzerland, their use is essentially limited to the few individuals who were responsible for their creation or installation. Development of a simple user oriented and forgiving input language for programs would accelerate the use of these models in practice. Another needed simulation research task is the generation of design guidelines for various passive and conservation components based on parametric studies using computer models and regional climate data, followed by statistical analyses of the data. Examples of needed guidelines are apparent in such issues as sizing glass area as a function of orientation given regional diurnal solar asymetries; in sizing mass, given a specified window area and thermal storage goal; and in selecting night insulation systems for various passive solar design approaches, again relative to the regional climate. 
Further research activity in test cell measurement of prototype solutions could well be limited to the existing inventory of test cells. Because the fronts of the cells are relatively easily interchanged with new prototype solutions, it is logical to continue research with the present facilities. One important example application would be the coupling of an attached greenhouse to a test cell to validate two zone simulation models, and in general, the performance of sunspaces under controlled conditions in the Swiss climate.

Measurement of several of the instrumented buildings will continue. More important than instrumenting additional buildings is the intensive, thorough, multifaceted analysis of the collected data, development of design recommendations based on these data, and definition of gaps in data requiring future instrumentation of buildings.

Finally, regarding research in the area of developing design tools and design data, important needed work has already been mentioned in the issues of sizing components and estimating the energy benefit of a given design strategy. An important specific task should be undertaken in developing micro computer software for architecture and engineering offices. 


\section{RESEARCH APPLICATIONS}

Finally, the research activities, discussed in the last section, can be examined by what types of buildings are forseen for application of the research.

The vast majority of research activity is occuring in the residential application area in Switzerland. Comparatively little research exists on the subject of commercial or institutional buildings configurations and energy implications. Research in these latter two applications is primarily regarding optimization of mechanical systems both in sizing and operation. Similarly, minimal research exists on what unique energy saving opportunities occur with mixed-use buildings (e.g. residential space built over retail space). Finally, almost no research could be found regarding analyses of the opportunities for conservation or passive solar use which exist when buildings are considered in aggregations.

It is the author's opinion that the most important area of work relative to application types, is the re-examination of the energy significance of the preconceived architectural forms assigned to residences, offices, shops, schools, hospitals, etc. What is the energy consumption of one of the recently built Swiss Technical University buildings compared to that of a residence on some normalized basis? Both fullfill the same environmental requirements to a large extent, room temperatures in the comfort zone, illumination (schools should require less energy for this because they are principally used during the daylight hours whereas homes are also occupied at night), and provision of fresh air. The objective of such research would not be to discover the obvious, but rather to emphasize the value in re-examining alternative architectural forms for society's various activities.

Research would also be valuable in mixed-building type applications, particaularly concept generation and simulation performance analysis. An example might be the design of an isolated gain passive solar system which uses the extensive opaque exterior wall area of retail space. 
Retail facilities do not value windows on exterior walls (except sidewalk display windows). Windows complicate the controlled lighting of goods. Also, exterior wall area occupied by windows reduces display or shelf area. Solar radiation incident on the opaque exterior wall area of retail space is therefor largely wasted and could readily be collected (and even augmented by heat from the lighting system) for use in residences built above the retail levels.

Multiple building applications are another important research subject. Example multiple building situations in Switzerland include the few instances of regional shopping centers (which are in effect multiple buildings linked by common circulation "halls", city centers (new shopping centers built in the middle of a town or city), terraced housing projects which typically step down a hillside, the downtown assemblage of buildings in towns and cities, the office parks of both private industry and government institutions, and school and university campuses. Analyses should be conducted on such muliple building situations to identify solar collection and use opportunities relative to times of space use and space heating or illumination requirements. Heating and cooling load balancing should also be explored. A classical application for analysis might be the enclosure of the main street of a city and the creation of a pedestrian sunspace thereby creating a tempered environment for shoppers and residents, and a tempered environment for half of all the vertical building surface area.

Multiple building studies should also be conducted to investigate the form implications and opportunities resulting from annual cycle thermal storage solar collection. Such system studies to date have tended to focus on the optimization of the solar collector/thermal storage system considered in isolation from the total conceptualization of the siting, form, and use mix of the building served. Improved integration of the components with the architecture and planning could result in enhanced economic performance. 


\section{Conclusion}

Energy conservation in buildings is a high priority research subject in Switzerland. To date investigations have been concentrated primarily in the subjects of insulation of the building envelope and in active solar heating systems. More recently, research has been begun on the subjects of passive solar energy use and combined solar and heatpump systems. Housing is the building occupancy type most frequently researched. Conservation measures and active solar systems have been studied in conjunction with multi-family housing, passive solar systems have been studied in conjunction with detached single-family housing. In the future, emphasis is expected to be given to passive solar applications for multi-family housing as well. Minimal research is forseen for office or retail buildings. Heating is expected to continue to be the most important energy research issue for buildings, with little or now research in lighting, airconditioning or ventilation. International cooperation will continue to be highly valued with the principal medium being the International Energy Agency. Direct communication between researchers is of course also valuable and the intent of publishing this report. 